\title{
Republic of Yemen: 2008 Article IV Consultation-Staff Report; Staff Statement and Supplement; Public Information Notice on the Executive Board Discussion; and Statement by the Executive Director for the Republic of Yemen
}

Under Article IV of the IMF's Articles of Agreement, the IMF holds bilateral discussions with members, usually every year. In the context of the 2008 Article IV consultation with the Republic of Yemen, the following documents have been released and are included in this package:

- $\quad$ The staff report for the 2008 Article IV consultation, prepared by a staff team of the IMF, following discussions that ended on November 3, 2008, with the officials of the Republic of Yemen on economic developments and policies. Based on information available at the time of these discussions, the staff report was completed on January 21, 2009. The views expressed in the staff report are those of the staff team and do not necessarily reflect the views of the Executive Board of the IMF.

- $\quad$ A supplement on the joint IMF/World Bank debt sustainability analysis.

- $\quad$ A staff statement of February 23, 2009, updating information on recent developments.

- $\quad$ A Public Information Notice (PIN) summarizing the views of the Executive Board as expressed during its February 23, 2009, discussion of the staff report that concluded the Article IV consultation.

- $\quad$ A statement by the Executive Director for the Republic of Yemen.

The policy of publication of staff reports and other documents allows for the deletion of market-sensitive information.

\author{
Copies of this report are available to the public from \\ International Monetary Fund $\bullet$ Publication Services \\ $70019^{\text {th }}$ Street, N.W. • Washington, D.C. 20431 \\ Telephone: (202) 623-7430 • Telefax: (202) 623-7201 \\ E-mail: publications@imf.org • Internet: http://www.imf.org
}

\section{International Monetary Fund Washington, D.C.}



INTERNATIONAL MONETARY FUND

REPUBLIC OF YEMEN

Staff Report for the 2008 Article IV Consultation

Prepared by the Staff Representatives for the 2008 Consultation with the Republic of Yemen Approved by Adam Bennett and David Marston

January 21, 2009

- $\quad$ Discussions took place from October 21 to November 3, 2008 in Sana'a. The mission comprised Mr. Schneider (head), Mr. Almounsor, Ms. Ongley, Mr. Pani (all MCD), and Ms. Rahman-Garrett (SECOP).

- $\quad$ The mission met with the prime minister, the deputy prime minister, and the ministers of finance, oil and minerals, industry and trade, civil service, and social affairs and labor; the governor of the central bank; and other government officials. The mission also met with various private sector representatives and donors.

- $\quad$ Yemen has accepted the obligations of Article VIII, Sections 2, 3, and 4, and maintains an exchange system free of restrictions on the making of payments and transfers for current international transactions.

- Yemen's de facto exchange rate regime is currently classified as a conventional peg, reflecting stability vis-à-vis the U.S. dollar since mid-2007, although the de jure classification remains free floating.

- $\quad$ The Executive Board concluded the 2007 Article IV consultation on September 17, 2007. The staff report and PIN were made available at: http://www.imf.org/external/country/YEM/index.htm.

- $\quad$ The quality and timeliness of data are weak but still adequate for surveillance purposes. Yemen participates in the General Data Dissemination Standard.

- A donor roundtable was conducted at the end of the mission. 


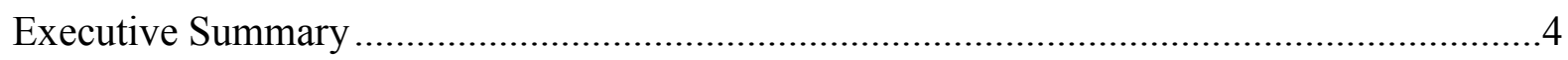

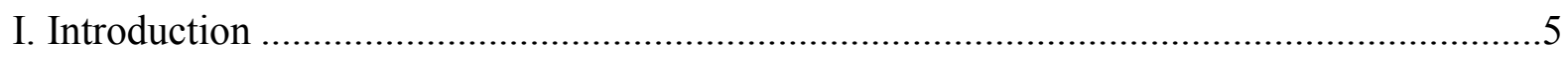

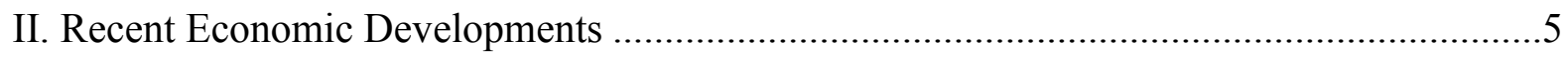

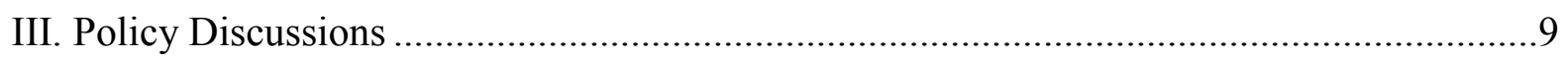

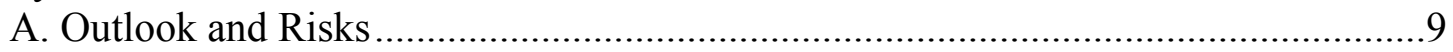

B. Policies for 2008-09: Reducing Inflation, Containing the Deficit.............................

C. Macroeconomic Policies for the Medium Term ………………………................12

D. Promoting Sustained Non-Hydrocarbon Growth....................................................16

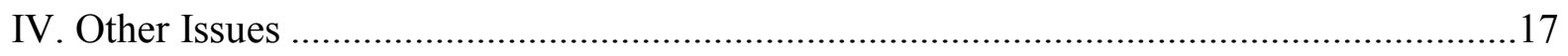

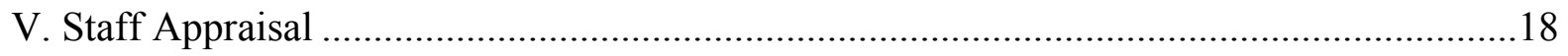

Text Boxes

1. Inflation Developments in Yemen and the Policy Response .............................................

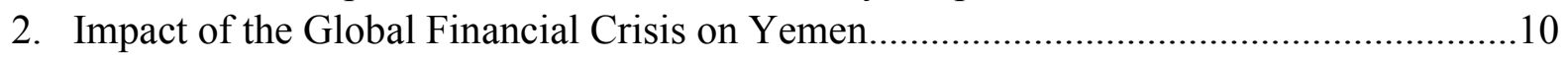

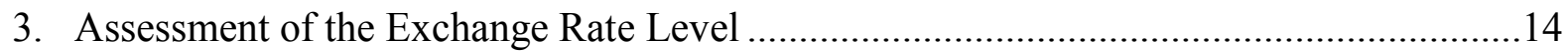

Text Figures

Oil Output, Government's Share and Exports, and Domestic Consumption, 2000-08 _.....5

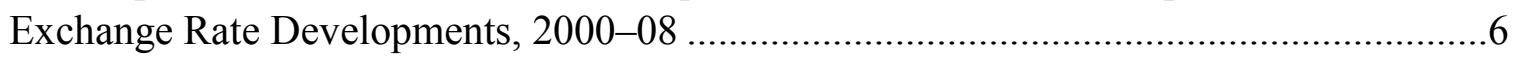

Twelve-Month Core Inflation by Component, January 2005 to Present .............................

Twelve-Month Food Price Inflation, January 2006-June 2008..........................................7

Asset Side of Broad Money ……………..................................................................

Sources of Government Revenue, 2008 (Proj.) …………..............................................10

Main Sources of Foreign Exchange, 2008 (Proj.)..........................................................10

Medium-Term Projections for Total Hydrocarbon Output

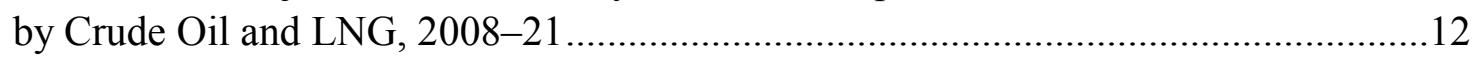

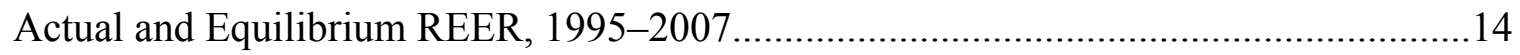

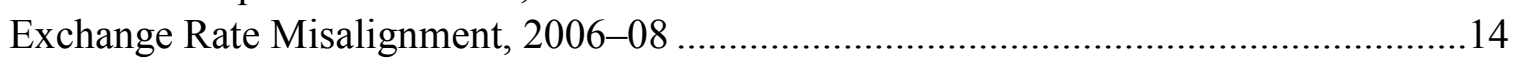

Estimated and Projected Equilibrium REER, 2007-13 ..................................................14

\section{Text Tables}

Standard Deviation of Monthly Food Inflation, January 2006-June 2008 ..........................7

Cross-Country Comparison of Financial Intermediation...................................................

Indicators of Banking System Financial Soundness, 2004-08 .........................................

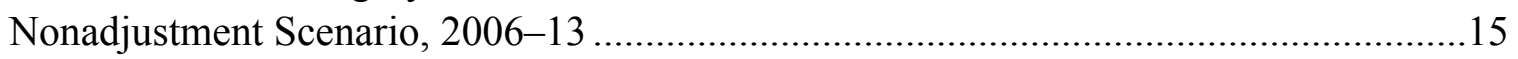




\section{Tables}

1. Selected Economic Indicators, 2005-13

2. General Government Finances, 2005-13 (In billions of Yemeni rials) ...........................22

3. General Government Finances, 2005-13 (In percent of GDP)....................................23

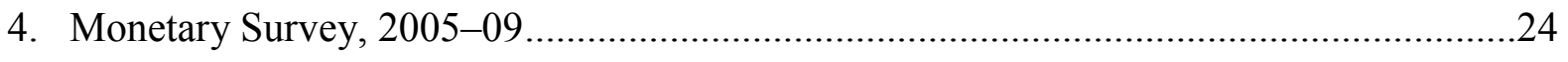

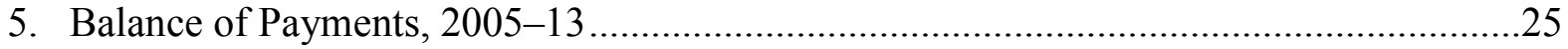

6. Millennium Development Goals, 1990-2006 .........................................................26 


\section{EXECUTIVE SUMMARY}

The 2008 Article IV consultation discussions with Yemen focused on the appropriate policy response to high inflation and mounting fiscal and external vulnerabilities.

\section{Background}

Recent economic performance has been mixed. Oil production continues to decline, and oil reserves are expected to be depleted in 10-12 years. Non-oil sector growth is estimated at about 5.3 percent in 2007 and 4.8 percent in 2008. Inflation has been volatile, reflecting the surge in international commodity prices and local drought. High oil prices buffered government revenue and exports in 2007 and the first half of 2008, but pressures are quickly mounting on public finances and the balance of payments as oil prices decline.

\section{Authorities' views}

- $\quad$ Efforts are being made to compress expenditures in 2008 so as to avoid upward pressure on inflation and reduce the deficit. The authorities remain committed to fiscal consolidation, including elimination of fuel subsidies, a smaller wage bill, and boosting non-oil revenues. Social stability concerns are key to the pace of reform.

- $\quad$ Monetary policy has sought to mitigate inflation through exchange rate stability and controlling domestic liquidity. A stable rial has brought benefits, but there are limits given balance of payments pressures and the need to minimize reserve losses.

- $\quad$ Financial intermediation is deepening. Banks' balance sheets continue to improve, but some weaknesses remain. Further strengthening the banking sector is a priority.

\section{Staff recommendations}

- $\quad$ The fuel subsidy system should be phased out in combination with an increase in, and better targeting of, social welfare transfers. The civil service wage bill should be reduced. Action is needed on overdue non-oil revenue reforms.

- Exchange rate stability should be maintained for the short term to dampen inflation, but monetary policy must focus more on price stability going forward. There is no clear evidence of significant exchange rate misalignment, but flexibility will be needed in coming years, given falling oil prices and dwindling oil reserves.

- $\quad$ Financial sector reform and modernization are essential to deepening financial intermediation and growth prospects. Further reform of the investment environment is key to fostering alternative sources of growth as oil output declines. 


\section{INTRODUCTION}

1. Yemen is one of the poorest countries in the Middle East. ${ }^{1}$ An estimated 35 percent of the population lives below the poverty line. Oil reserves are expected to be depleted in about 10-12 years. Yemen has few other natural resources and is also facing depletion of its groundwater. These challenges are compounded by an expanding population, poor infrastructure, weak institutional capacity, a fragile security situation, and the widespread use of qat - a mild narcotic accounting for over one-third of agricultural production and about a quarter of total water resource use.

2. Economic reforms slowed after the 1990s, and urgently need to be reinvigorated. Although a number of reform initiatives emerged in recent years-including civil service and public financial management (PFM) reforms, a major adjustment to fuel subsidies in 2005, a new general sales tax (GST), an anticorruption drive, and improvements to the social safety net - most have been only partially implemented and with significant delays. Fund advice on preparing for the transition to a non-oil economy has had limited traction, particularly in the context of record world oil prices and increasing political and security constraints. However, recent developments - the sharp decline in oil output in 2007 and the even sharper decline in oil prices in late 2008 - are bringing a new sense of urgency to the debate on economic reform.

\section{RECENT ECONOMIC DEVELOPMENTS}

3. Recent economic performance in Yemen has been mixed. Oil production continues to decline. Non-oil economic activity has grown at a reasonable rate but is likely to have slowed moderately in 2008. Inflation has been a key concern. Pressures related to the global slowdown and the falling price of oil began to materialize in late 2008 .

- $\quad$ Overall real GDP grew by about 3.3 percent in 2007 , reflecting real non-oil growth of 5.3 percent and a

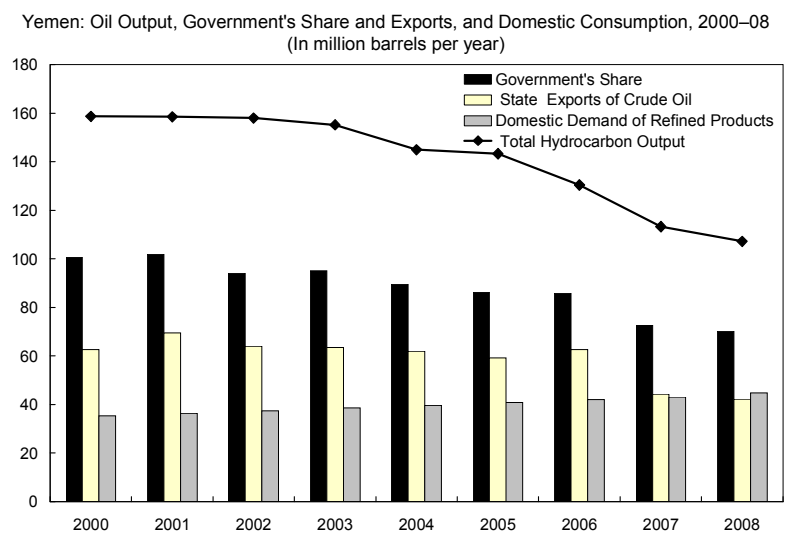

\footnotetext{
${ }^{1}$ Yemen ranks last among 13 Middle East and North Africa countries surveyed in the World Bank's World Development Indicators in terms of per capita income, life expectancy, completion of primary education, and access to improved water.
} 
13.1 percent decline in oil output. ${ }^{2}$ Overall growth should pick up in 2008 , with somewhat lower non-oil growth of 4.8 percent compensated for by a smaller decline in oil output.

- Core inflation (excluding qat) rose to 27 percent by May 2008 -reflecting the surge in global commodity prices. Inflation has since declined to about 18 percent in October. Some spillover to nonfood items may have emerged. Inflation excluding qat and food reached a record 18 percent by June-mainly due to the cost of services, clothing, housing, and fuels (Box 1).

- A sizeable fiscal deficit emerged in 2007, and another is likely for 2008. A sharp decline in oil production, coupled with inflexible government expenditure, led to an overall fiscal deficit of 5.8 percent in 2007. For 2008, a deficit of around 5-6 percent of GDP is possible in the wake of the recent drop in international oil prices, continued rigid expenditures, and limited non-oil revenue improvements.

- Monetary policy in 2008 focused on exchange rate stability and controlling excess liquidity in the domestic banking system. The rial has remained steady against the U.S. dollar since mid-2007, helping to mitigate imported inflation. In real effective terms, the rial appreciated by 9.5 percent in the 12 months to October. The Central Bank of Yemen (CBY) used its full allowance of Treasury bills to absorb domestic liquidity in the first nine months of the year, and has since relied on central bank certificates of deposit (CDs) and additional foreign exchange auctions. Broad money and reserve money growth through October were 15.5 percent and 10.9 percent, respectively. The benchmark deposit rate remains fixed at

Yemen: Exchange Rate Developments, 2000-08

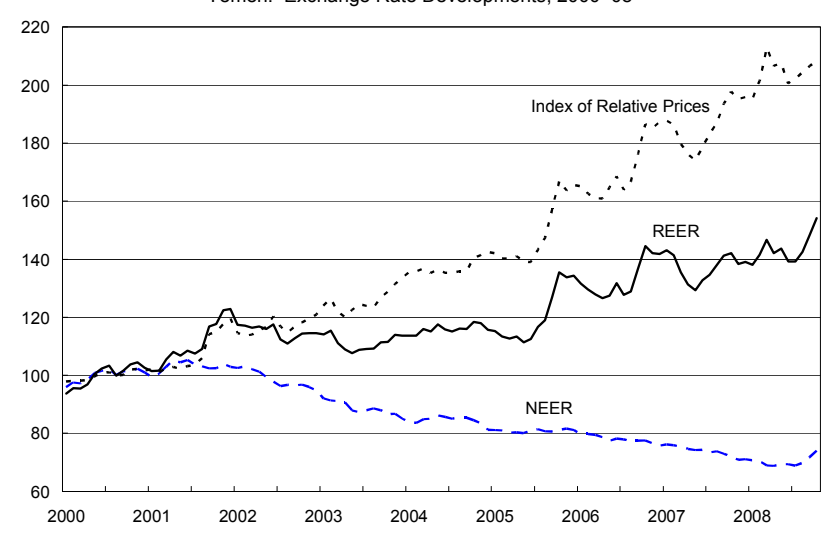
13 percent.

\footnotetext{
${ }^{2}$ The Central Statistics Office (CSO) recently revised and rebased national accounts series with the help of a technical expert from the United Nations Economic and Social Commission for Western Asia (ESCWA). The exercise is an important step forward in establishing a more timely and credible set of data on GDP. However, technical problems remain and work will continue with the objective of producing a revised and consistent data set by the end of 2008. The staff and authorities agreed to use the established national accounts series for the purpose of this report.
} 


\section{Box 1. Inflation Developments in Yemen and the Policy Response}

Inflation developments: Inflation in Yemen has been extremely volatile in the past year. During January-July 2008, 12-month core inflation (i.e., excluding qat) averaged 19 percent. Food prices have been the main impetus, with food inflation averaging 22 percent during the first two quarters of 2008 - in line with the most vulnerable net food importing countries in the region. While non-tradables have not generally been a major source of inflationdue at least in part to administered domestic fuel prices - some of the recent push from commodity prices seems to be feeding into other components of the CPI (such as housing and related items). Though the worst of the food crisis appears to be over, recent developments underscored Yemen's vulnerability to commodity shocks.

Social and macroeconomic impact: The surge in commodity prices is likely to have aggravated poverty, particularly for small farmers and the landless. Increasing poverty and food prices

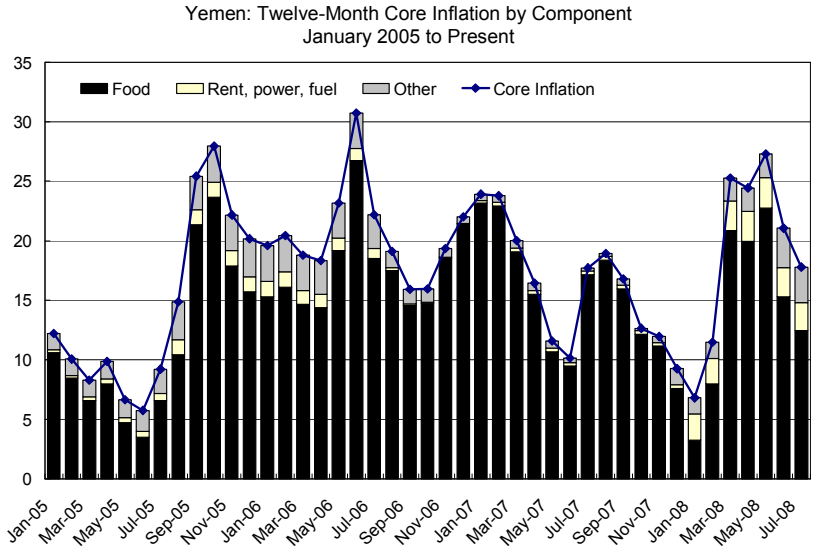

Standard Deviation of Monthly Food Inflation January 2006-June 2008

also appear to have contributed to growing social tensions. Record international fuel prices for the first half of 2008 also raised the fuel subsidy bill and added to the 2008 government fiscal deficit.

Policy response and external assistance: The government has sought to mitigate the impact of surging prices through direct support to consumers and increasing the supply of commodities. In March 2008, the government increased wages, pensions, and social welfare benefits - at an estimated cost of YRL 60 billion in 2008. The government also intervened in the wheat market through direct sales to the public. International donors have increased their support to Yemen through a mix of loans, grants, and direct food aid. The central

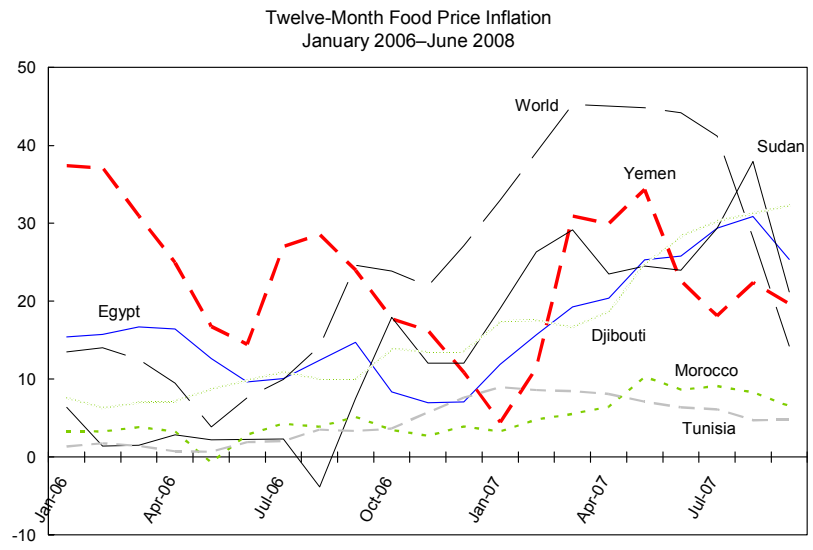
bank has meanwhile maintained a prudent monetary policy and suspended the practice of steadily depreciating the rial in favor of exchange rate stability in order to mitigate the extent of imported inflation. 
- $\quad$ The external current account shifted to a deficit of 7 percent of GDP in 2007, compared with an average surplus of about 2.4 percent during 2002-06. This shift reflected mainly FDI-financed imports for a liquefied natural gas (LNG) plant. The external accounts benefited from record oil prices during the first part of 2008, but pressures appear to be emerging in the wake of declining oil prices. The current account is projected to remain in deficit (about 2 percent of GDP) in 2008. CBY foreign exchange

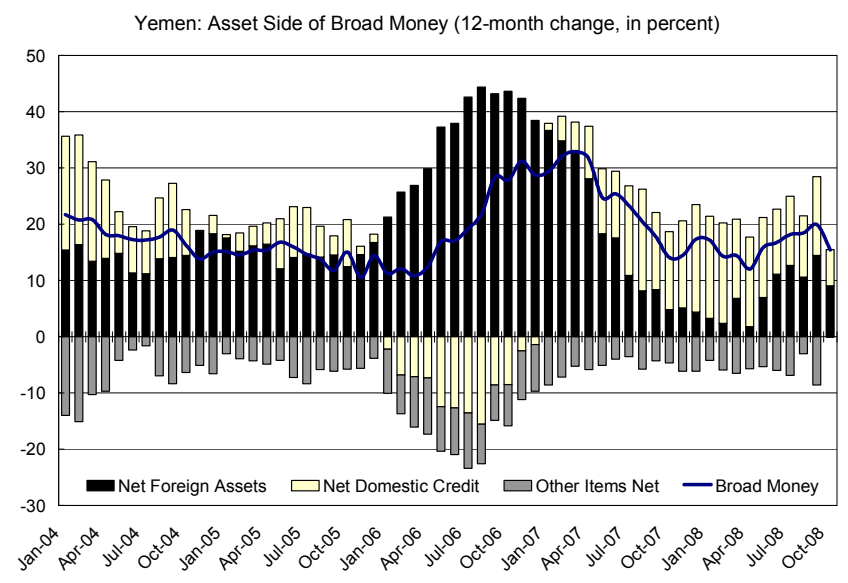
reserves look to remain roughly the same as at end-2007.

- Financial intermediation is deepening but remains shallow compared to the region. Nonperforming loans (NPLs) remain high but have fallen steadily as a share of total loans in recent years. Capital adequacy improved in mid-2008 compared to end-2007. Further improvements in capital adequacy are expected by end-2009, in line with revised minimum capital requirements for banks in Yemen. Dollarization has declined steadily in the past few years.

\section{Yemen maintains close} cooperation with the donor community, but a substantial portion of the 2006 Consultative Group (CG) pledges have yet to be translated into actual disbursements or commitments.

\begin{tabular}{lrrr}
\multicolumn{4}{c}{ Cross-Country Comparison of Financial Intermediation } \\
\hline $\begin{array}{r}\text { Broad Money / } \\
\text { GDP }\end{array}$ & $\begin{array}{r}\text { Priv. Credit / } \\
\text { Broad Money }\end{array}$ & $\begin{array}{r}\text { Priv. Credit / } \\
\text { GDP }\end{array}$ \\
\hline Lebanon & 282.5 & 25.5 & 72.0 \\
Jordan & 137.4 & 71.2 & 97.8 \\
Morocco & 105.0 & 67.1 & 70.4 \\
Tunisia & 66.6 & 92.0 & 61.3 \\
Egypt & 89.7 & 51.7 & 46.4 \\
Oman & 38.2 & 97.7 & 37.3 \\
Sudan & 21.0 & 60.1 & 12.6 \\
Yemen & 36.8 & 22.2 & 8.2 \\
\hline
\end{tabular}

Source: IFS and WEO databases; all data end-2007.

Yemen: Indicators of Banking System Financial Soundness, 2004-08 1/ (In percent; unless otherwise indicated)

\begin{tabular}{|c|c|c|c|c|c|}
\hline & 2004 & 2005 & 2006 & 2007 & $\begin{array}{l}2008 \\
\text { June }\end{array}$ \\
\hline \multicolumn{6}{|l|}{ Capital adequacy } \\
\hline Risk-weighted capital adequacy ratio & 10.0 & 10.0 & 12.0 & 8.7 & 9.4 \\
\hline Capital ( net worth ) to assets & 5.0 & 5.0 & 6.5 & 4.9 & 5.5 \\
\hline \multicolumn{6}{|l|}{ Portfolio quality } \\
\hline Nonperforming loans to total assets & 6.8 & 7.1 & 5.7 & 5.4 & 5.5 \\
\hline Nonperforming loans to gross loans & 24.0 & 24.0 & 23.0 & 19.5 & 18.0 \\
\hline \multicolumn{6}{|l|}{ Portfolio performance } \\
\hline Average return on assets & 0.8 & 1.1 & 1.2 & 1.6 & 0.9 \\
\hline Average return on equity & 15.1 & 17.8 & 17.3 & 19.7 & 12.2 \\
\hline \multicolumn{6}{|l|}{ Exposure to exchange rate risk } \\
\hline Total foreign currency assets (billions of rials) & 309.1 & 379.3 & 469.3 & 576.3 & 599.2 \\
\hline Total foreign currency liabilities (billions of rials) & 288.9 & 354.8 & 458.1 & 520.1 & 523.2 \\
\hline
\end{tabular}




\section{Policy Discussions}

4. Discussions focused on (i) risks to the outlook from the global slowdown and the dramatic drop in oil prices; (ii) appropriate fiscal and monetary policies to keep inflation on a downward path and address the recent and prospective deterioration in public finances; and (iii) macroeconomic and structural reforms to ensure fiscal and external sustainability.

\section{A. Outlook and Risks}

5. Yemen remains relatively insulated from the financial side of the current world economic crisis (Box 2). Yemeni banks have relatively low exposure to private foreign lending, which centers around trade flows. Portfolio investment is quite limited, given the absence of a domestic stock market or commercial credit market. Yemen's main foreign asset - the CBY's reserves - are highly liquid and kept predominantly in the form of deposits in international banks. While Yemen could suffer from a decline in external financing (either through lower remittances, FDI, or official financing flows), these risks have yet to materialize, and would move more slowly than financial contagion.

\section{Yemen remains vulnerable to commodity shocks and the effects of slower} regional and world economic activity. Although government revenue and the balance of payments benefited from the high price of oil during the first half of 2008, the economy suffered from higher imported food and input prices. With the global slowdown and sharp decline in crude oil and other commodity prices, these risks have essentially reversed. Pressures expected to materialize over the medium term with declining oil production have become near-term considerations. Without substantial expenditure and revenue reforms, the fiscal deficit will become increasingly difficult to finance, and balance of payments pressures will mount (notwithstanding the CBY's substantial reserve cushion). Slower regional growth is also projected to bring lower levels of non-oil foreign investment than might have been expected (contributing to lower growth), as well as lower inward remittances from expatriate Yemeni workers in the Gulf and elsewhere.

\section{B. Policies for 2008-09: Reducing Inflation, Containing the Deficit}

\section{The authorities recognized the need to further reduce inflation and address} emerging imbalances. Recent data suggest that the worst of the turbulence in international food prices has passed. Price pressures in Yemen should continue to ease with lower world commodity prices (and falling transport costs). Nevertheless, the authorities agreed additional efforts would be necessary to bring twelve-month inflation to 15 percent or less by end-year. The authorities also concurred that the risks to public finances and external sustainability had increased considerably since the end of the oil-price boom and that fiscal and monetary policy would need to be carefully coordinated to meet this challenge. 


\section{Box 2. Impact of the Global Financial Crisis on Yemen}

The risk of financial contagion from the global economic turbulence appears low. Yemen is not closely integrated with international financial and capital markets. The small size of the domestic banking system and low level of financial intermediation would also contain the direct impact, even if access to bank credit is restricted. Liquidity risk to the foreign exchange reserves of CBY also appears low, as these assets are mainly in the form of deposits at large commercial banks in Europe. The CBY increased foreign exchange auctions in September to maintain a stable exchange rate and calm market jitters about the availability of foreign exchange, but no additional action has yet been necessary.

Yemen does remain vulnerable to a real shock through lower oil prices. Oil exports account for a large share of government revenue and the bulk of foreign exchange receipts. The fiscal impact could be softened by a corresponding decline in fuel subsides (even with unchanged domestic fuel prices). A further drop in international oil prices would increase pressure on Yemen's fiscal and external accounts. For each $\$ 10 / \mathrm{bbl}$ decline, the overall fiscal balance and current account would deteriorate by almost 1 percentage point of GDP. Pressure on the external accounts may be partly alleviated if international commodity prices continue to decline.

Yemen: Sources of Government Revenue, 2008 (Proj.)

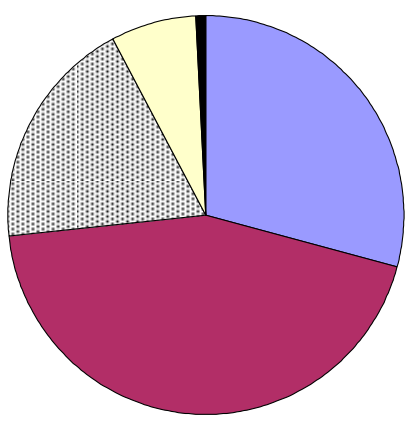

Yemen: Main Sources of Foreign Exchange, 2008 (Proj.)

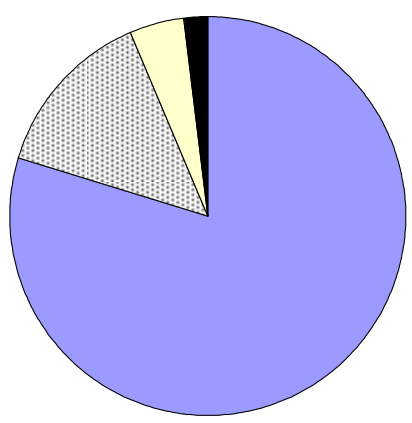

$\square$ Crude oil exports

ĐWorkers' remittances

口Loans/Grants

- Nonoil FDI

Softer growth and financial distress in partner countries may also negatively impact Yemen's access to external financial resources-namely remittances, foreign direct investment (FDI) and concessional donor financing. While the likelihood or potential magnitude of these secondary effects are difficult to gauge (especially given data limitations in Yemen), stress tests prepared by staff suggest that:

- A 50 percent decline in non-oil FDI would likely soften growth, and reduce import demand and the current account deficit (each by around 0.5 percent of GDP).

- A 50 percent fall in remittances could widen the current account deficit by over 0.5 percent of GDP, notwithstanding some import compression, and marginally lower real GDP growth.

- Fifty percent lower donor disbursements would marginally widen the overall fiscal deficit and, assuming capital spending is maintained to avoid a negative impact on growth, domestic debt would increase by 1.2 percent of GDP.

Absent alternative financing, each of these scenarios could result in a loss of foreign exchange reserves of up to $1 / 2$ a month of imports. Under a combined loss of non-oil FDI, remittances, and donor financing, the fiscal and current account deficits would deteriorate by $1-1 \frac{1}{2}$ percent of GDP, public sector domestic debt would rise by around $2 \frac{1}{2}-3$ percent of GDP, and international reserves would drop by one month of imports. 


\section{Fiscal policy}

8. The authorities indicated that they would seek to compress spending during the remainder of 2008 to reduce upward pressure on prices. They noted that some fuel subsidies were reduced in August, when pressures began to emerge. ${ }^{3}$ Spending under the supplementary budget was largely constrained to the additional cost of the fuel subsidy, but also covered the ad hoc increase in wages, pensions, and social welfare transfers granted in March. Additional compression of some spending commitments under the original budget may be possible.

\section{The authorities concurred that the risks to public finances will be more} pronounced in 2009. Based on an oil price of $\$ 55$ per barrel, the approved government budget implies an overall deficit of about 8.6 percent of GDP - the highest since the oil price shock of 1998. Staff and the authorities agreed that a deficit of this magnitude would be difficult to finance and that additional actions would be necessary to preserve the credibility of public finances. With a view to keeping the overall deficit below 6 percent of GDP (consistent with domestic financing of 4.5 percent of $\mathrm{GDP}^{4}$ ), the staff offered a fiscal scenario based on a set of adjustment measures and the most recent WEO oil price $(\$ 54.25$ per barrel). Most significant among the adjustment measures were (i) a reduction in fuel subsidies by mid-year; (ii) a nominal freeze on the public sector wage bill; ${ }^{5}$ and (iii) overdue actions to boost tax revenues. The staff also urged the authorities to follow up on earlier pledges of donor support, and to seek concessional external financing, where possible.

\section{Monetary and exchange rate policy}

\section{Given the priority of reducing inflation, the CBY indicated it would continue to} focus on exchange rate stability in the short term. In addition to alleviating imported inflation, stability vis-à-vis the U.S. dollar appears to have helped confidence in the rial and lowered dollarization. The mission noted that the monetary stance and focus on exchange rate stability had been broadly appropriate, but that there remained some risk of inflation becoming entrenched. The CBY indicated it would remain vigilant in mopping up excess

\footnotetext{
${ }^{3}$ In August 2008, the authorities raised the price of diesel for sales to selected industries (mainly concrete and steel companies). However, this accounts for only a small portion of subsidized domestic consumption.

${ }^{4}$ Most domestic financing is through Treasury bills, with the remainder in the form of unsecuritized loans. Domestic debt is relatively short-term and expensive $(3,6$, and 12 months maturities, with an average interest rate of about 16 percent). The scope for domestic financing of the 2009 budget deficit thus appears limited.

${ }^{5}$ Public sector wages and salaries in the official budget are lower than that proposed by staff because the authorities used the 2007 budget as a base and did not take into account the one-off increase granted in March 2008 or the annual Ramadan bonus.
} 
liquidity in the banking system. Given that it has already exhausted its yearly allowance of Treasury bills, the CBY would continue to issue CDs and conduct further foreign exchange auctions - even at the cost of international reserves. The CBY also indicated that other options, such as increasing the benchmark deposit rate, increasing reserve requirements, or using Islamic financial instruments, ${ }^{6}$ were also under discussion.

\section{While there is no evidence of current misalignment, the rial is probably} moderately overvalued from a medium-term perspective. The prospective decline in oil production over the next 10-12 years suggests that the real exchange rate will need to decline over the medium term in order to render the economy more competitive and thereby generate non-oil export growth for Yemen. The current policy of maintaining broad stability for the rial seems appropriate for the short term given the need to keep inflation down. If fiscal consolidation proceeds as envisioned and inflation continues to fall, greater flexibility in the rial should be considered as the economy and the fiscal accounts adjust to lower oil revenue. (Box 3).

\section{Macroeconomic Policies for the Medium Term}

\section{Yemen's medium-term outlook remains dominated by the expected depletion of}

oil reserves. The latest information suggests that total recoverable oil (proven reserves plus a portion of probable and possible reserves) is about 1.1 billion barrels. Assuming oil production declines gradually (an average annual drop of about 5 percent per year), oil reserves will be exhausted by 2021. Starting in 2009, LNG production will help alleviate the impact on government revenue and exports, but will not make up for the loss of crude oil.

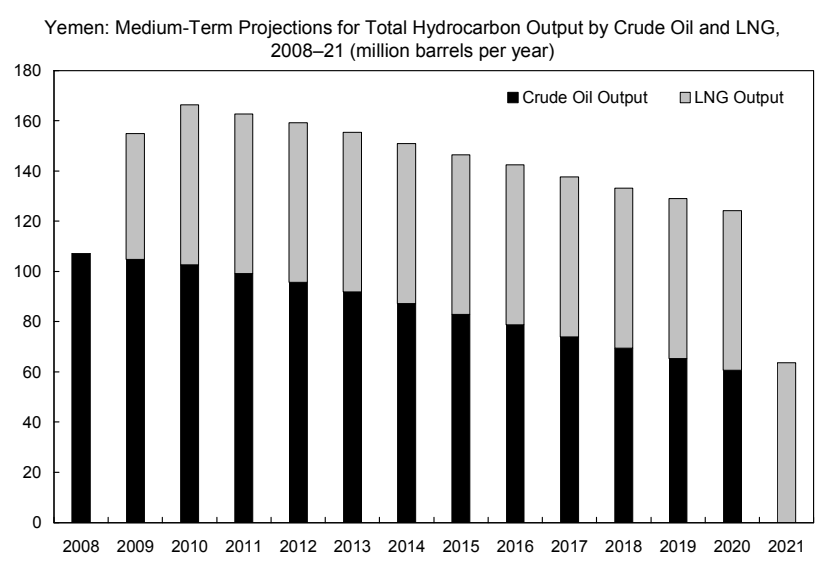

13. There was broad consensus among government agencies that current policies are not sustainable. The staff presented a scenario of unchanged macroeconomic policies to highlight the risks of inaction. Under this scenario, external financing and non-oil growth would be lower. The fiscal deficit would expand quickly to 15 percent of GDP by 2012; reserve cover would decline as the external current account deficit widened-raising the risk of a sharp adjustment in the exchange rate. Assuming that domestic and external financing gaps could be filled (which is doubtful given the limited appetite for domestic debt, Yemen's lack of access to international capital markets, and tighter conditions for official financing),

\footnotetext{
${ }^{6}$ The CBY has formally requested technical assistance from the IMF on how to design and make operational financial instruments compliant with Shari'a law.
} 
public debt would rise from 38 percent of GDP in 2008 to over 65 percent in the medium term.

14. The authorities acknowledged the need for a comprehensive adjustment to fiscal policy to ensure medium-term stability. They agreed that the centerpiece of this adjustment lies in addressing the two largest components of current expenditure- the fuel subsidy and the public sector wage bill, which together account for about 50 percent of total spending. Staff prepared an adjustment scenario (Tables 1-6) to illustrate the extent and magnitude of actions necessary to maintain macroeconomic stability and prevent debt distress. The exercise was guided by a debt sustainability analysis (DSA) geared around keeping the public debt-to-GDP ratio below 50 percent over the medium and long term.

\section{Even with a front-loaded adjustment to fuel subsidies in 2009, the non-oil} primary deficit $^{7}$ would need to adjust by an average of 2 percent of GDP per year in the medium term and by about 0.5 percent of GDP per year thereafter. Key measures in this adjustment process would include (i) gradually eliminating fuel subsidies in 2009-11, accompanied by increased (and better targeted) social welfare transfers; (ii) reducing the civil service wage bill by about 2 percentage points of GDP by 2013; (iii) implementing fully the GST in 2009, and increasing the rate from 5 percent to 10 percent in 2011, and to 12 percent in 2014; and (iv) streamlining the income tax through simultaneously lowering the rate from 35 percent to 20 percent while eliminating all exemptions in the customs, income tax, and investment laws. These measures would also need to be underpinned by more rapid progress on PFM reform to ensure tighter commitment control and careful debt management. ${ }^{8}$

\section{Staff emphasized the risk of debt distress illustrated in the DSA. Staff}

highlighted that, even with full implementation of the envisioned reform agenda, one debt indicator (PV of debt-to-exports) violates the sustainability threshold over the long term. Other debt indicators are breached under the sensitivity analysis. Given Yemen's vulnerability to external shocks, low institutional capacity, and the downside risks associated with implementing the reform agenda, Yemen remains at a high risk of debt distress.

\footnotetext{
${ }^{7}$ The non-oil primary deficit declines by 13 percentage points of GDP in 2009 under the staff's adjustment scenario. Of this, 10 percentage points relate to the change in the fuel subsidy bill, of which about 8 percentage points stem from the change in the international oil price versus the administered domestic price.

${ }^{8}$ The full and effective implementation of the Accounting and Financial Management Information System (AFMIS) is a key element in advancing the PFM agenda. Other important elements include the full transition to budget accounting in line with GFSM 2001, and the introduction of a Treasury system.
} 


\section{Box 3. Assessment of the Exchange Rate Level}

\section{There is no evidence to suggest that the exchange rate is currently misaligned, but it seems likely that the real exchange rate will need to depreciate over the medium term.}

Over the past ten years Yemen's real effective exchange rate (REER) has appreciated — consistent with movements in the price of oil—while the current account has generally been in surplus. In 2007, the REER appreciated (on average) by about 3 percent compared to 2006-mainly due to inflation, as the nominal value of the rial was steady vis-à-vis the U.S. dollar.

The current account balance net of imports related to hydrocarbon sector FDI registered a surplus of about 3 percent of GDP in 2007, allowing for a further buildup in central bank reserves. With the recent decline in oil prices, monthly foreign exchange auctions by the central bank have increased in size, suggesting that downward pressure on the rial will resume.

A simple regression of monthly real effective exchange rate data on the price of oil shows some undervaluation in early 2008 , which began to reverse in September with the fall in oil prices.

Estimates obtained using the CGER methodology ${ }^{1}$ are mixed (and thus merely indicative) owing to data weaknesses and other shortcomings. The equilibrium real effective exchange rate (EREER) approach does not yield evidence of misalignment, and predicts a moderate depreciation of the EREER in the medium term. The macroeconomic balance (MB) approach shows some undervaluation in 2007, and predicts a more marked medium-term depreciation.

The drop in oil export receipts induced by the recent fall in oil prices and by the expected medium-term decline in oil production will add downward pressure on the equilibrium exchange rate, supporting the view that the rial will have to

Yemen: Actual and Equilibrium REER, 1995-2007 (Simple Regression and EREER Approach; $2000=100$ )

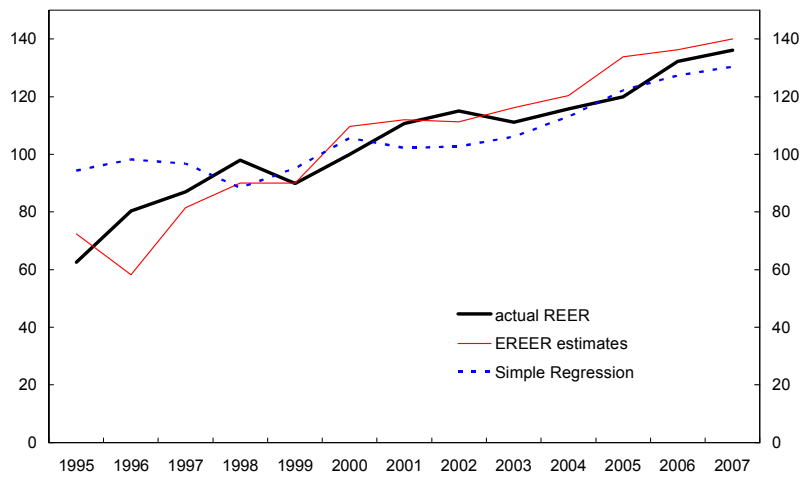

Yemen: Exchange Rate Misalignment, 2006-08 (based on a simple regression on the price of oil)

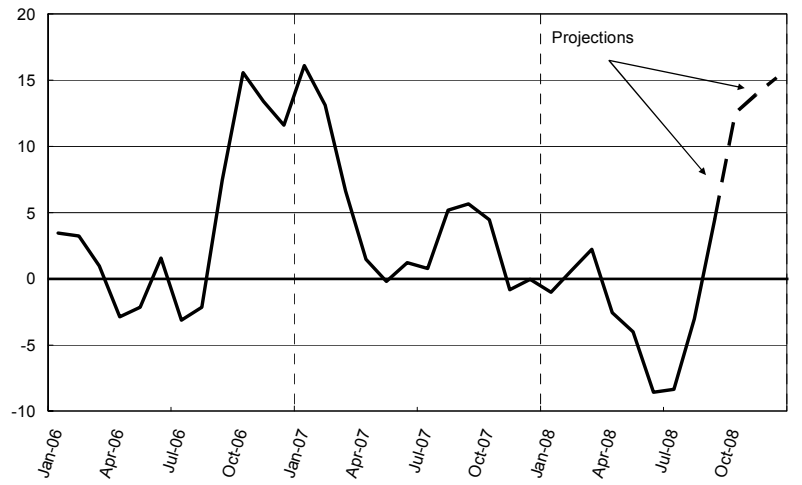

Yemen: Estimated and Projected Equilibrium REER, 2007-13 (Actual REER in $2007=100$ )

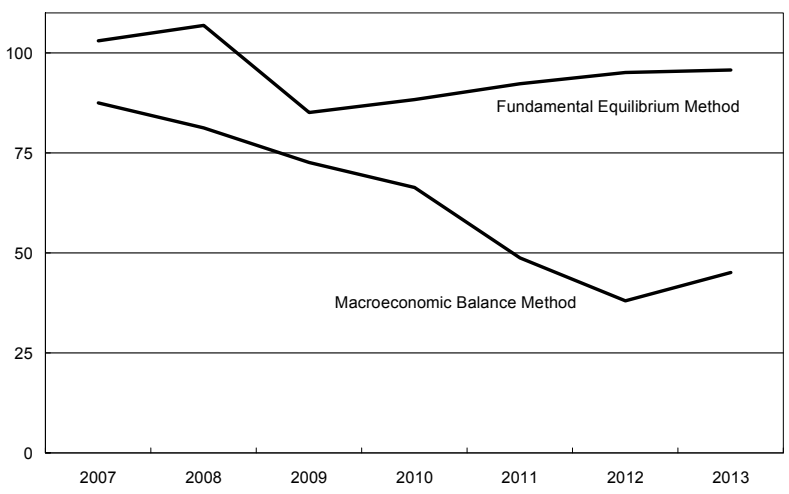
depreciate in real effective terms to maintain external sustainability. The magnitude of adjustment is uncertain, and will depend partly on the pace and scope of fiscal consolidation and inflation reduction.

${ }^{1}$ For an illustration of the CGER methodology see www.imf.org/external/pp/longres.aspx?id=3957). 
Yemen: Nonadjustment Scenario, 2006-13

\begin{tabular}{|c|c|c|c|c|c|c|c|c|}
\hline & \multirow[b]{2}{*}{2006} & \multirow{2}{*}{$\begin{array}{c}\text { Prel. } \\
2007\end{array}$} & \multicolumn{6}{|c|}{ Projections } \\
\hline & & & 2008 & 2009 & 2010 & 2011 & 2012 & 2013 \\
\hline & \multicolumn{8}{|c|}{ (In percent of GDP) } \\
\hline \multicolumn{9}{|l|}{ Government finances } \\
\hline Total revenue and grants & 38.6 & 33.2 & 37.4 & 24.0 & 23.3 & 22.1 & 20.7 & 24.4 \\
\hline Hydrocarbon revenue & 28.9 & 22.6 & 27.5 & 14.4 & 13.8 & 12.6 & 11.0 & 14.3 \\
\hline Non-hydrocarbon revenue & 9.3 & 10.3 & 9.5 & 9.0 & 9.1 & 9.2 & 9.3 & 9.7 \\
\hline Tax revenue & 7.1 & 7.3 & 7.0 & 7.0 & 7.1 & 7.3 & 7.4 & 7.8 \\
\hline Nontax & 2.2 & 2.9 & 2.5 & 2.0 & 2.0 & 2.0 & 1.9 & 1.9 \\
\hline Grants & 0.4 & 0.3 & 0.4 & 0.6 & 0.4 & 0.3 & 0.4 & 0.4 \\
\hline Total expenditure and net lending & 37.4 & 40.3 & 43.0 & 33.8 & 34.6 & 35.1 & 35.7 & 38.6 \\
\hline Current expenditure & 28.2 & 31.4 & 34.6 & 25.4 & 26.2 & 26.8 & 27.4 & 30.4 \\
\hline \multicolumn{9}{|l|}{ Of which: } \\
\hline Wages and salaries & 9.9 & 10.9 & 10.4 & 10.0 & 10.0 & 10.0 & 10.0 & 10.0 \\
\hline Interest obligations & 2.3 & 2.3 & 2.2 & 2.5 & 3.1 & 3.9 & 4.8 & 6.0 \\
\hline Subsidies and transfers & 11.1 & 12.4 & 18.0 & 8.8 & 8.9 & 8.7 & 8.3 & 10.1 \\
\hline \multicolumn{9}{|l|}{ Of which: } \\
\hline Petroleum & 8.1 & 9.3 & 14.5 & 5.5 & 5.6 & 5.4 & 4.9 & 6.7 \\
\hline Social welfare fund & 0.7 & 0.7 & 1.1 & 0.7 & 0.7 & 0.7 & 0.7 & 0.7 \\
\hline Capital expenditure & 7.3 & 7.2 & 7.1 & 7.2 & 7.2 & 7.2 & 7.2 & 7.2 \\
\hline Net lending & 1.8 & 1.8 & 1.3 & 1.2 & 1.2 & 1.1 & 1.1 & 1.0 \\
\hline Overall balance (cash basis) $1 /$ & -0.7 & -5.8 & -5.6 & -9.8 & -11.3 & -13.0 & -15.0 & -14.2 \\
\hline Non-hydrocarbon primary fiscal balance (cash) 2/ & -42.0 & -37.8 & -45.2 & -28.3 & -29.0 & -27.8 & -26.2 & -30.0 \\
\hline \multirow[t]{2}{*}{ Gross Public Sector Debt } & 40.8 & 40.4 & 38.1 & 44.9 & 47.5 & 52.9 & 59.8 & 67.3 \\
\hline & \multicolumn{8}{|c|}{ (Change in percent) } \\
\hline \multicolumn{9}{|l|}{ Production and prices } \\
\hline Overall real GDP at market prices & 3.2 & 3.3 & 3.9 & 7.2 & 4.1 & 3.0 & 2.7 & 2.3 \\
\hline Real non-hydrocarbon GDP & 4.7 & 5.3 & 4.8 & 3.9 & 3.8 & 3.7 & 3.3 & 2.8 \\
\hline Real hydrocarbon GDP & -8.3 & -13.1 & -5.4 & 44.5 & 7.4 & -2.2 & -2.1 & -2.4 \\
\hline Core consumer price index (annual average) $3 /$ & 20.3 & 15.8 & 16.3 & 16.3 & 17.6 & 17.9 & 18.3 & 23.3 \\
\hline \multirow[t]{2}{*}{ Core consumer price index (12-month) $3 /$} & 22.0 & 9.3 & 15.0 & 17.5 & 17.8 & 18.1 & 18.5 & 28.0 \\
\hline & \multicolumn{8}{|c|}{ (In percent of GDP) } \\
\hline \multicolumn{9}{|l|}{ External sector } \\
\hline Current account & 1.1 & -7.0 & -2.0 & -2.6 & -1.7 & -2.4 & -3.2 & -4.8 \\
\hline External debt & 28.7 & 26.9 & 22.3 & 21.7 & 19.3 & 17.9 & 16.7 & 26.6 \\
\hline Central Bank own gross foreign reserves (months of imports) & 10.0 & 10.2 & 13.3 & 9.9 & 8.5 & 6.7 & 4.5 & 3.0 \\
\hline
\end{tabular}

Sources: Yemeni authorities; and Fund staff estimates and projections.

1/ Includes statistical discrepancy.

2/ In percent of non-hydrocarbon GDP, includes statistical discrepancy.

3/ The core $\mathrm{CPI}$ is defined as the $\mathrm{CPI}$ excluding qat.

17. On the DSA, the authorities highlighted that, for now, the debt-to-GDP ratio remains relatively low, and that a public debt law with ceilings for domestic, external, and overall public debt is currently under discussion. Staff noted these points, but emphasized the recent deterioration in key macroeconomic aggregates, the forward-looking nature of the macroeconomic framework and the DSA, as well as the recent increase in risks. The staff urged the authorities to consider an average increase in domestic fuel prices of 65 percent by mid-2009 to help keep the budget deficit below 6 percent of GDP.

\section{The authorities were particularly conscious of the need to boost non-oil} revenues, but implementation of key reforms remains in flux. The long-delayed GST was implemented in 2007, but as a concession to the powerful business community, was applied 
to a relatively narrow segment of taxpayers. ${ }^{9}$ Full implementation is planned for early 2009. The ongoing income tax simplification is moving ahead but has not been aligned with the 2009 budget. The required package of income tax rate reductions and elimination of exemptions is at some risk, as revisions to the income tax, customs, and investment laws were submitted separately to parliament. Staff emphasized that action on non-oil revenues was critical to addressing the looming budget shortfall in 2009 and beyond.

\section{Monetary and exchange rate policy will have to adjust to shifting fundamentals.}

The external current account pressures expected in 2009 are unlikely to diminish. Steady progress in fiscal consolidation should provide some relief and help curb inflation. However, staff believe that Yemen's real effective exchange rate will have to depreciate over the medium term in line with its equilibrium. The prospective decline in oil output may bring downward pressure on the exchange rate-which could lead to a rapid and excessive depletion of the central bank's foreign exchange reserves and necessitate a depreciation of the nominal exchange rate. Minimizing the inflationary impact of a depreciation of the rial, however, will require steady fiscal consolidation, structural reforms that enable markets to adjust quickly to changes in relative prices, sound debt management, and an effective monetary framework focused on price stability.

\section{Promoting Sustained Non-Hydrocarbon Growth}

\section{New sources of growth will need to be developed to ameliorate the expected} decline in hydrocarbon output. Investment in infrastructure will be vital, and the authorities have also focused on creating an environment conducive to private sector investment. Yemen has launched a new one-stop shop for investors in the past year, and has made it easier to obtain municipal licenses and to register with the chamber of commerce and tax office. Other reforms include a new procurement law, the establishment of an active anticorruption authority, and a review of labor and company laws. Yemen's ranking on the World Bank's Doing Business report jumped from 113 in 2008 to 98 in 2009.

\section{The authorities concurred that a sound and vibrant financial system will be} essential to non-oil economic growth. They noted a range of financial sector reforms initiated or implemented over the past year, including (i) passage of a deposit insurance law and establishment of a deposit insurance corporation; (ii) amendments to the 1994 Islamic Banking Law (submitted to parliament) to eliminate limits on foreign ownership and allow commercial banks to open an Islamic branch; and (iii) a microfinance law, expected to be passed by parliament in 2009. Further work needs to be done to establish a credit registry,

\footnotetext{
${ }^{9}$ The GST was implemented in February 2007 at a rate of 5 percent (compared to the recommended 10 percent) and with only partial coverage (in practice, it applies only to importers and manufacturers, and traders are subject to administrative assessment of their liabilities).
} 
liberalize interest rates, ${ }^{10}$ establish an active interbank market, and address the weaknesses in contract enforcement that have encouraged banks to focus their lending on a relatively small number of well-known clients. Enforcing existing prudential standards also remains critical to further reducing NPLs. The authorities expressed some interest in an update to the 2000 FSAP but have yet to make a formal request.

\section{The authorities continue to pursue closer ties with the region and the world} economy. Working party discussions on Yemen's accession to the WTO have been in train since 2004. Bilateral negotiations on goods and services have been concluded with China and are ongoing with Australia, Canada, the EC, Japan, Korea, and the U.S. Yemen continues to pursue membership in the Gulf Cooperation Council (GCC) — primarily through the Yemeni-Gulf Technical Committee. In mid-2008, GCC members tasked the Secretary General to conduct an integrated study on the prospects for Yemen's accession into the bloc.

\section{OTHER ISSUES}

23. The quality and timeliness of Yemen's economic data remain a concern. There have been a number of improvements to the provision of monetary data in the past year, although data on financial sector indicators are typically available only during missions. Balance of payments data are also weak and suffer from long lags, making timely assessments of the supply and demand for foreign exchange difficult. Provision of fiscal data is improving slowly, although the timeliness and consistency of the quarterly financial bulletins could be improved. Additional technical assistance on shifting to GFSM 2001 should facilitate this process. National accounts and inflation data are, for the time being, in a state of transition. A revised and rebased set of national accounts was formulated in cooperation with an external expert in 2008, and is now being reviewed and finalized. A similar overhaul of the CPI is underway, in consultation with a technical expert from METAC. Similar efforts should be accorded to developing a PPI, to enhance the accuracy of the national accounts.

\section{Yemen is working on establishing an anti-money laundering/combating the} financing of terrorism (AML/CFT) framework. An AML law was passed in 2003 but was broadly considered inadequate. A new unified draft law covering both AML and CFT issues is with parliament for approval.

\footnotetext{
${ }^{10}$ The benchmark interest rate on deposits has been fixed at 13 percent for the last nine years. In the staff's view, the minimum interest rate on deposits has distorted market signals and outlived its usefulness. It was originally intended to mobilize deposits in the mid-1990s, when inflation was high and exchange rate depreciations frequent.
} 


\section{Staff Appraisal}

25. Yemen faces serious short-term and medium-term risks to economic and financial stability. These risks have been present for some time (and were expected to intensify with the depletion of oil reserves) but have been masked by high oil prices in recent years. The sharp drop in oil production in 2007 and the current fall in international oil prices have brought these risks back to center stage, highlighting the need for early adjustment.

26. Fiscal policy needs urgently to adapt to a changing environment. Even if oil prices recover from current lows, the expected depletion of oil reserves will require a steady reduction in the non-oil primary deficit to maintain economic and financial stability. The agenda of key expenditure and revenue reforms discussed in successive Article IV missions needs to be implemented without further delay. In this context, staff attach particular importance to the following:

- An increase in domestic fuel prices by an average of 65 percent as soon as feasible in 2009, followed by further increases to align domestic and international prices by 2012 . The impact on the poor should be cushioned by parallel increases in, and better targeting of, social welfare spending.

- Holding the wage bill constant in nominal terms in 2009—-preferably through attrition, restructuring, and elimination of ghost workers rather than a wage freeze. The wage bill should be reduced further over the medium-term, ideally to a level equivalent to about 8 percent of GDP by 2013.

- Implementing fully the GST in January 2009, followed by successive increases in the GST rate in later years.

- Implementing the tax simplification project by eliminating tax exemptions in the customs, income tax, and investment laws in exchange for a reduction in the tax rate from 35 percent to 20 percent, effective January 2009.

27. Monetary policy was broadly appropriate in 2008 , but will also need to respond to increased risks. Fiscal consolidation will be a critical step in alleviating pressure on the external accounts. However, given the expected decline in oil production (only partially offset by the advent of LNG), the external current account is likely to remain in deficit in 2009 and beyond. In this environment, maintaining the rial steady vis-à-vis the U.S. dollar could come at the expense of central bank international reserves. While the CBY should continue to intervene to reduce short-term volatility in the value of the rial, greater exchange rate flexibility may become necessary to avoid a dramatic decline in international reserves. The central bank should closely monitor monthly cash flows in this respect and, in the context of lower inflation, be prepared to allow the rial to move in line with fundamental shifts in the equilibrium exchange rate. While there is no evidence to suggest that the 
exchange rate is currently misaligned, it appears likely that the real exchange rate will need to depreciate over the medium term.

28. The adjustment path outlined by staff is ambitious, but reflects the reality of recent changes to the outlook and charts a course that should help to ensure macroeconomic stability. The sharp and sustained reduction in oil prices, the likely downturn in regional growth, and the downside risks to investment and external financing all highlight the need for action on a long overdue agenda of reforms. Nonetheless, the staff recognize that the outlook is subject to considerable risks. The need to provide humanitarian relief (to address recent flooding in the south) and a desire to ensure social and political stability may constrain budgetary reform. Insufficient progress on fiscal consolidation could threaten the authorities' inflation objectives, or potentially crowd out private sector credit, with attendant risks to non-hydrocarbon growth. A corresponding increase in public debt and loss of reserves could quickly erode fiscal and external sustainability. Moreover, the potential for a sharper-than-expected decline in oil prices (or loss of other foreign financing) in a rapidly changing global environment would compound these pressures, necessitating further adjustment.

29. As fiscal consolidation proceeds, the central bank should focus more closely on price stability and establishing a more effective monetary framework. The staff notes efforts to strengthen liquidity forecasting at the CBY and coordination with the MOF. To enhance the role of monetary policy, the CBY should also consider such steps as (i) making a public commitment to price stability; (ii) liberalizing interest rates to remove the current distortion to the cost of capital in Yemen, facilitate an increase in private sector lending, and (in the context of fiscal consolidation and lower inflation) reduce the high interest cost of public debt; and (iii) developing a broader range of monetary policy instruments.

\section{Deepening financial intermediation remains critical for medium-term growth.}

Recent initiatives by the CBY have concentrated on (i) raising banks' minimum capital requirements to ensure safety and soundness; (ii) introducing a deposit insurance scheme; and (iii) seeking to level the playing field between conventional and Islamic banks by adjusting reserve requirements and remuneration of reserves. More remains to be done. Liberalizing interest rates, establishing a credit registry, and encouraging a domestic interbank market would be critical next steps. Enforcement of existing prudential regulations and standards will also be key - particularly given that NPLs remain high (albeit declining). An update to the 2000 Financial Sector Assessment (FSAP) could be useful as a roadmap for further financial sector reform.

31. Data provision remains adequate for surveillance, but Yemen is in a transitional phase in several areas. Long overdue work on the national accounts and prices is now coming to fruition, but further TA is needed to ensure the provision of robust and credible data. The transition to GFSM 2001 for the fiscal accounts has advanced but remains a work in progress and could benefit from additional TA. Finally, improving the balance of 
payments is now more essential than ever, given the need for a timely and accurate assessment of foreign exchange flows.

32. It is proposed that the next Article IV consultation discussions be held on the standard 12-month cycle. 
Table 1. Republic of Yemen: Selected Economic Indicators, 2005-13

\begin{tabular}{|c|c|c|c|c|c|c|c|c|c|}
\hline & \multirow[b]{2}{*}{2005} & \multirow[b]{2}{*}{2006} & \multirow{2}{*}{$\frac{\text { Prel. }}{2007}$} & \multicolumn{6}{|c|}{ Projections } \\
\hline & & & & 2008 & 2009 & 2010 & 2011 & 2012 & 2013 \\
\hline & \multicolumn{9}{|c|}{ (Change in percent) } \\
\hline \multicolumn{10}{|l|}{ Production and prices } \\
\hline Real GDP at market prices & 5.6 & 3.2 & 3.3 & 3.9 & 7.7 & 5.0 & 4.4 & 4.5 & 4.5 \\
\hline Real non-hydrocarbon GDP & 6.5 & 4.7 & 5.3 & 4.8 & 4.4 & 4.8 & 5.2 & 5.3 & 5.3 \\
\hline Real hydrocarbon GDP & -0.8 & -8.3 & -13.1 & -5.4 & 44.5 & 7.4 & -2.2 & -2.1 & -2.4 \\
\hline Consumer price index (annual average) & 11.8 & 18.2 & 12.5 & 16.6 & 14.0 & 12.3 & 11.6 & 7.4 & 5.6 \\
\hline Core consumer price index (annual average) $1 /$ & 14.5 & 20.3 & 15.8 & 16.3 & 15.0 & 13.6 & 12.7 & 11.6 & 9.5 \\
\hline Core consumer price index (12-month) $1 /$ & 20.2 & 22.0 & 9.3 & 15.0 & 15.0 & 12.3 & 13.1 & 10.0 & 9.0 \\
\hline Hydrocarbon production (1,000 barrels/day) & 393 & 357 & 310 & 293 & 424 & 456 & 446 & 435 & 426 \\
\hline & \multicolumn{9}{|c|}{ (In percent of GDP) } \\
\hline \multicolumn{10}{|l|}{ Investment and savings } \\
\hline Gross domestic investment & 18.5 & 16.4 & 17.2 & 16.9 & 15.5 & 16.5 & 17.4 & 18.3 & 19.0 \\
\hline Government & 7.9 & 7.3 & 7.2 & 7.1 & 6.0 & 6.0 & 6.4 & 6.8 & 7.0 \\
\hline Other & 10.6 & 9.1 & 10.0 & 9.8 & 9.5 & 10.5 & 11.0 & 11.5 & 12.0 \\
\hline Gross national savings & 22.3 & 17.4 & 10.2 & 14.9 & 13.0 & 15.3 & 15.9 & 16.3 & 17.5 \\
\hline Government & 8.1 & 10.3 & 1.8 & 2.8 & 1.3 & 2.2 & 4.5 & 5.7 & 5.8 \\
\hline Other & 14.2 & 7.1 & 8.5 & 12.1 & 11.7 & 13.2 & 11.4 & 10.6 & 11.8 \\
\hline \multicolumn{10}{|l|}{ Government finance } \\
\hline Total revenue and grants & 34.9 & 38.6 & 33.2 & 37.4 & 24.9 & 24.6 & 26.0 & 25.1 & 24.7 \\
\hline Total expenditure and net lending & 36.8 & 37.4 & 40.3 & 43.0 & 30.6 & 29.5 & 28.7 & 27.1 & 26.9 \\
\hline Overall balance (cash basis) $2 /$ & -0.6 & -0.7 & -5.8 & -5.6 & -5.7 & -4.8 & -2.8 & -2.0 & -2.2 \\
\hline Non-hydrocarbon primary fiscal balance (cash) 3/ & -38.4 & -42.0 & -37.8 & -45.2 & -23.0 & -21.8 & -17.4 & -14.6 & -14.2 \\
\hline Gross Public Sector Debt & 43.8 & 40.8 & 40.4 & 38.1 & 41.1 & 38.7 & 36.1 & 33.6 & 32.6 \\
\hline External debt & 30.9 & 28.7 & 26.9 & 22.3 & 21.8 & 19.4 & 18.0 & 17.1 & 17.2 \\
\hline Domestic debt & 12.9 & 12.1 & 13.5 & 15.9 & 19.3 & 19.3 & 18.1 & 16.5 & 15.4 \\
\hline & \multicolumn{9}{|c|}{ (Twelve-month change in percent) } \\
\hline \multicolumn{10}{|l|}{ Monetary data } \\
\hline Broad money & 14.4 & 28.8 & 17.4 & 23.9 & 14.0 & $\ldots$ & $\ldots$ & $\ldots$ & $\ldots$ \\
\hline Reserve money & 17.8 & 17.1 & 11.3 & 15.6 & 11.4 & $\ldots$ & $\ldots$ & $\ldots$ & $\ldots$ \\
\hline Credit to private sector & 21.3 & 16.7 & 35.7 & 23.0 & 25.9 & $\ldots$ & $\ldots$ & $\ldots$ & $\ldots$ \\
\hline Benchmark deposit interest rate (percent p.a.) & 13.0 & 13.0 & 13.0 & 13.0 & $\ldots$ & $\ldots$ & $\ldots$ & $\ldots$ & $\ldots$ \\
\hline \multirow[t]{2}{*}{ Velocity (non-oil GDP/M2) } & 2.1 & 2.0 & 2.0 & 2.0 & 2.1 & $\ldots$ & $\ldots$ & $\ldots$ & $\ldots$ \\
\hline & \multicolumn{9}{|c|}{ (In millions of U.S. dollars, unless otherwise indicated) } \\
\hline \multicolumn{10}{|l|}{ External sector } \\
\hline Exports, f.o.b. & 6,413 & 7,316 & 7,050 & 8,628 & 6,312 & 7,441 & 7,752 & 7,802 & 7,832 \\
\hline Of which: hydrocarbon (oil and gas) & 5,952 & 6,733 & 6,264 & 7,771 & 5,395 & 6,461 & 6,693 & 6,637 & 6,527 \\
\hline Of which: non-hydrocarbon & 461 & 583 & 786 & 856 & 916 & 981 & 1,059 & 1,165 & 1,305 \\
\hline Imports, f.o.b. & $-4,713$ & $-5,926$ & $-7,490$ & $-7,473$ & $-5,716$ & $-6,271$ & $-6,822$ & $-7,340$ & $-7,696$ \\
\hline Current account (in percent of GDP) & 3.8 & 1.1 & -7.0 & -2.0 & -2.4 & -1.2 & -1.5 & -1.9 & -1.5 \\
\hline \multicolumn{10}{|l|}{ Memorandum items: } \\
\hline Crude export oil price (U.S. dollar/barrel) 4/ & 51.2 & 62.8 & 72.3 & 96.0 & 52.8 & 63.3 & 69.8 & 73.5 & 76.0 \\
\hline Central Bank own gross foreign reserves $5 /$ & 5,338 & 6,798 & 6,969 & 7,016 & 6,697 & 6,427 & 5,971 & 5,385 & 4,946 \\
\hline In months of imports $5 /$ & 11.6 & 10.0 & 10.2 & 13.3 & 10.3 & 9.4 & 8.5 & 7.5 & 6.5 \\
\hline Real effective exchange rate $(2000=100)$ & 120.4 & 133.0 & 137.7 & $\ldots$ & $\ldots$ & $\ldots$ & $\ldots$ & $\ldots$ & $\ldots$ \\
\hline \multicolumn{10}{|l|}{ Nominal GDP at market prices } \\
\hline In billions of Yemeni rials & 3,209 & 3,760 & 4,309 & 5,308 & 5,693 & 6,905 & 8,004 & 9,137 & 10,356 \\
\hline In millions of U.S. dollars & 16,732 & 19,064 & 21,653 & 26,585 & 28,463 & 34,527 & 40,018 & 45,684 & 49,317 \\
\hline Per capita GDP (in U.S. dollars) & 798 & 882 & 971 & 1,157 & 1,202 & 1,415 & 1,592 & 1,765 & 1,850 \\
\hline Population (in thousands) & 20,975 & 21,622 & 22,290 & 22,978 & 23,687 & 24,398 & 25,130 & 25,884 & 26,660 \\
\hline
\end{tabular}

Sources: Yemeni authorities; and Fund staff estimates and projections.

$1 /$ The core $\mathrm{CPI}$ is defined as the $\mathrm{CPI}$ excluding qat.

2/ Includes statistical discrepancy.

3/ In percent of non-hydrocarbon GDP; includes statistical discrepancy.

4/ The price of Yemeni oil differs from the WEO price because it sometimes trades at a discount.

5/ Gross reserves minus commercial bank and pension fund foreign exchange deposits held with the Central Bank of Yemen. 
Table 2. Republic of Yemen: General Government Finances, 2005-13

(In billions of Yemeni rials)

\begin{tabular}{|c|c|c|c|c|c|c|c|c|c|c|}
\hline & \multirow[t]{2}{*}{2005} & \multirow[t]{2}{*}{2006} & \multirow{2}{*}{$\begin{array}{l}2007 \\
\text { Prel. }\end{array}$} & \multirow{2}{*}{$\begin{array}{l}2008 \\
\text { Proj. }\end{array}$} & \multicolumn{2}{|c|}{2009} & \multirow{2}{*}{$\begin{array}{c}2010 \\
\text { Proj. }\end{array}$} & \multirow{2}{*}{$\begin{array}{l}2011 \\
\text { Proj. }\end{array}$} & \multirow{2}{*}{$\begin{array}{c}2012 \\
\text { Proj. }\end{array}$} & \multirow{2}{*}{$\begin{array}{l}2013 \\
\text { Proj }\end{array}$} \\
\hline & & & & & Budget 1/ & Proj. & & & & \\
\hline Total revenue and grants & 1,121 & 1,450 & 1,429 & 1,985 & 1,446 & 1,419 & 1,701 & 2,078 & 2,298 & 2,560 \\
\hline Hydrocarbon revenue & 842 & 1,085 & 973 & 1,461 & 835 & 822 & 979 & 1,057 & 1,094 & 1,167 \\
\hline \multicolumn{11}{|l|}{ Of which: } \\
\hline Crude oil exports & 482 & 612 & 510 & 584 & 253 & 276 & 300 & 283 & 245 & 255 \\
\hline Non-hydrocarbon revenue & 265 & 349 & 442 & 505 & 532 & 554 & 692 & 982 & 1,147 & 1,333 \\
\hline Tax revenue & 235 & 266 & 315 & 371 & 396 & 421 & 531 & 795 & 934 & 1,091 \\
\hline Income taxes & 89 & 123 & 144 & 178 & $\ldots$ & 200 & 246 & 293 & 344 & 397 \\
\hline Taxes on goods and services & 89 & 101 & 118 & 136 & $\ldots$ & 163 & 219 & 430 & 512 & 605 \\
\hline Custom taxes & 52 & 36 & 44 & 48 & $\ldots$ & 48 & 53 & 56 & 60 & 68 \\
\hline Other taxes & 6 & 6 & 8 & 9 & $\ldots$ & 10 & 13 & 16 & 19 & 21 \\
\hline Nontax & 31 & 83 & 126 & 134 & 136 & 133 & 161 & 187 & 213 & 242 \\
\hline Grants & 14 & 15 & 15 & 19 & 79 & 43 & 30 & 38 & 57 & 60 \\
\hline Total expenditure and net lending & 1,180 & 1,405 & 1,739 & 2,281 & 1,933 & 1,744 & 2,035 & 2,300 & 2,479 & 2,786 \\
\hline Current expenditure & 862 & 1,062 & 1,352 & 1,835 & 1,435 & 1,345 & 1,550 & 1,716 & 1,774 & 1,961 \\
\hline Wages and salaries $2 /$ & 281 & 373 & 470 & 550 & 538 & 550 & 612 & 689 & 761 & 841 \\
\hline Goods and services & 93 & 128 & 167 & 159 & 177 & 160 & 198 & 233 & 271 & 312 \\
\hline Operations and maintenance & 15 & 19 & 35 & 27 & 31 & 28 & 38 & 46 & 56 & 66 \\
\hline Interest obligations & 69 & 87 & 97 & 115 & 106 & 143 & 184 & 212 & 220 & 213 \\
\hline Domestic & 60 & 76 & 87 & 101 & 90 & 128 & 168 & 193 & 199 & 188 \\
\hline External & 9 & 11 & 10 & 15 & 16 & 15 & 17 & 19 & 21 & 24 \\
\hline Subsidies and transfers & 385 & 418 & 534 & 957 & 554 & 435 & 483 & 494 & 420 & 476 \\
\hline Subsidies & 286 & 309 & 408 & 773 & 369 & 213 & 193 & 134 & 0 & 0 \\
\hline \multicolumn{11}{|l|}{ Of which: } \\
\hline Petroleum products (including LPG) & 280 & 303 & 402 & 767 & 337 & 207 & 187 & 128 & 0 & 0 \\
\hline Electricity & 6 & 6 & 6 & 6 & 6 & 6 & 6 & 6 & 0 & 0 \\
\hline Transfers & 99 & 109 & 126 & 184 & 185 & 222 & 290 & 360 & 420 & 476 \\
\hline Of which: social welfare fund & 22 & 26 & 31 & 57 & $\ldots$ & 89 & 129 & 174 & 207 & 235 \\
\hline Other & 19 & 37 & 50 & 28 & 29 & 29 & 36 & 41 & 47 & 53 \\
\hline Capital expenditure & 254 & 274 & 310 & 378 & 409 & 340 & 417 & 509 & 618 & 727 \\
\hline Of which: foreign financed & $\ldots$ & $\ldots$ & 60 & 62 & 161 & 106 & 137 & 176 & 212 & 235 \\
\hline Net lending & 63 & 69 & 76 & 69 & 90 & 59 & 69 & 75 & 86 & 98 \\
\hline Overall balance (commitment) & -58 & 45 & -309 & -296 & -487 & -325 & -335 & -222 & -181 & -226 \\
\hline Pending obligations & 0 & 0 & 0 & 0 & 0 & 0 & 0 & 0 & 0 & 0 \\
\hline External interest paid & 0 & 0 & 0 & 0 & 0 & 0 & 0 & 0 & 0 & 0 \\
\hline Overall balance (cash) & -58 & 45 & -309 & -296 & -487 & -325 & -335 & -222 & -181 & -226 \\
\hline Discrepancy & 38 & -71 & 60 & 0 & 0 & 0 & 0 & 0 & 0 & 0 \\
\hline Financing & 20 & 26 & 250 & 296 & 487 & 325 & 335 & 222 & 181 & 226 \\
\hline External & 13 & 53 & 47 & 35 & 52 & 68 & 100 & 107 & 122 & 138 \\
\hline Domestic & 7 & -26 & 203 & 261 & 436 & 257 & 235 & 115 & 59 & 88 \\
\hline \multicolumn{11}{|l|}{ Memorandum items: } \\
\hline $\begin{array}{l}\text { Overall balance (cash), excluding grants and } \\
\text { foreign-financed capital expenditure } 3 /\end{array}$ & 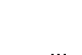 & & & & & & -228 & & -27 & -51 \\
\hline $\begin{array}{l}\text { toreign-fınanced capıtal expenditure 3/ } \\
\text { Primary balance (cash) 3/ }\end{array}$ & $\begin{array}{c}\ldots \\
49\end{array}$ & $\begin{array}{c}\cdots \\
61\end{array}$ & $\begin{array}{l}-205 \\
-153\end{array}$ & $\begin{array}{l}-254 \\
-181\end{array}$ & $\begin{array}{l}\cdots \\
\cdots\end{array}$ & $\begin{array}{l}-262 \\
-182\end{array}$ & $\begin{array}{l}-228 \\
-150\end{array}$ & $\begin{array}{l}-84 \\
-10\end{array}$ & $\begin{array}{r}-21 \\
39\end{array}$ & $\begin{array}{l}-51 \\
-13\end{array}$ \\
\hline Non-hydrocarbon primary balance (cash) 3/ & -793 & $-1,025$ & $-1,125$ & $-1,642$ & $\cdots$ & $-1,004$ & $-1,129$ & $-1,067$ & $-1,055$ & $-1,180$ \\
\hline Non-hydrocarbon primary balance (cash), excluding & & & & & & & & & & \\
\hline grants and foreign-financed capital expenditure $3 /$ & $\cdots$ & & $-1,065$ & $-1,580$ & $\ldots$ & -898 & -992 & -891 & -843 & -946 \\
\hline Social spending $4 /$ & 239 & 278 & & $\ldots$ & $\ldots$ & 478 & 600 & 720 & 831 & 942 \\
\hline Gross public debt $5 /$ & 1,405 & 1,535 & 1,741 & 2,024 & $\ldots$ & 2,341 & 2,670 & 2,888 & 3,068 & 3,372 \\
\hline Net public debt $5 /$ & 1,189 & 1,240 & 1,518 & 1,801 & $\ldots$ & 2,119 & 2,448 & 2,665 & 2,846 & 3,149 \\
\hline
\end{tabular}

Sources: Ministry of Finance; Ministry of Planning; and Fund staff estimates.

1/ The 2009 budget estimates are based on the Yemeni authorities' oil price (US $\$ 55 /$ barrel) and volume assumptions.

2/ The 2009 budgeted wage bill is based on the original 2008 budget figure. Staff estimates also include a one-month Ramadan bonus and account

for the wage increases announced in March 2008.

3/ Based on overall (cash) balance and statistical discrepancy, with relevant exclusions.

4/ Consists of education, health, social assistance, and social welfare fund transfers; covers central and local government units.

5/ Refers to central and local governments. 
Table 3. Republic of Yemen: General Government Finances, 2005-13

(In percent of GDP)

\begin{tabular}{|c|c|c|c|c|c|c|c|c|c|c|}
\hline & \multirow[t]{2}{*}{2005} & \multirow[t]{2}{*}{2006} & \multirow{2}{*}{$\begin{array}{c}2007 \\
\text { Prel. }\end{array}$} & \multirow{2}{*}{$\begin{array}{c}2008 \\
\text { Proj. }\end{array}$} & \multicolumn{2}{|c|}{2009} & \multirow{2}{*}{$\begin{array}{l}2010 \\
\text { Proj. }\end{array}$} & \multirow{2}{*}{$\begin{array}{l}2011 \\
\text { Proj. }\end{array}$} & \multirow{2}{*}{$\begin{array}{l}2012 \\
\text { Proj. }\end{array}$} & \multirow{2}{*}{$\begin{array}{l}2013 \\
\text { Proj. }\end{array}$} \\
\hline & & & & & Budget 1/ & Proj. & & & & \\
\hline Total revenue and grants & 34.9 & 38.6 & 33.2 & 37.4 & 25.4 & 24.9 & 24.6 & 26.0 & 25.1 & 24.7 \\
\hline Hydrocarbon revenue & 26.2 & 28.9 & 22.6 & 27.5 & 14.7 & 14.4 & 14.2 & 13.2 & 12.0 & 11.3 \\
\hline \multicolumn{11}{|l|}{ Of which: } \\
\hline Crude oil exports & 15.0 & 16.3 & 11.8 & 11.0 & 4.4 & 4.9 & 4.3 & 3.5 & 2.7 & 2.5 \\
\hline LNG exports & 0.0 & 0.0 & 0.0 & 0.0 & 0.8 & 1.0 & 1.0 & 0.8 & 0.7 & 0.7 \\
\hline Non-hydrocarbon revenue & 8.3 & 9.3 & 10.3 & 9.5 & 9.3 & 9.7 & 10.0 & 12.3 & 12.6 & 12.9 \\
\hline Tax revenue & 7.3 & 7.1 & 7.3 & 7.0 & 7.0 & 7.4 & 7.7 & 9.9 & 10.2 & 10.5 \\
\hline Income taxes & 2.8 & 3.3 & 3.4 & 3.4 & $\ldots$ & 3.5 & 3.6 & 3.7 & 3.8 & 3.8 \\
\hline Taxes on goods and services & 2.8 & 2.7 & 2.7 & 2.6 & $\ldots$ & 2.9 & 3.2 & 5.4 & 5.6 & 5.8 \\
\hline Custom taxes & 1.6 & 1.0 & 1.0 & 0.9 & $\ldots$ & 0.8 & 0.8 & 0.7 & 0.7 & 0.7 \\
\hline Other taxes & 0.2 & 0.2 & 0.2 & 0.2 & $\ldots$ & 0.2 & 0.2 & 0.2 & 0.2 & 0.2 \\
\hline Nontax & 1.0 & 2.2 & 2.9 & 2.5 & 2.4 & 2.3 & 2.3 & 2.3 & 2.3 & 2.3 \\
\hline Grants & 0.4 & 0.4 & 0.3 & 0.4 & 1.4 & 0.8 & 0.4 & 0.5 & 0.6 & 0.6 \\
\hline Total expenditure and net lending & 36.8 & 37.4 & 40.3 & 43.0 & 34.0 & 30.6 & 29.5 & 28.7 & 27.1 & 26.9 \\
\hline Current expenditure & 26.9 & 28.2 & 31.4 & 34.6 & 25.2 & 23.6 & 22.4 & 21.4 & 19.4 & 18.9 \\
\hline Wages and salaries 2/ & 8.7 & 9.9 & 10.9 & 10.4 & 9.4 & 9.7 & 8.9 & 8.6 & 8.3 & 8.1 \\
\hline Goods and services & 2.9 & 3.4 & 3.9 & 3.0 & 3.1 & 2.8 & 2.9 & 2.9 & 3.0 & 3.0 \\
\hline Operations and maintenance & 0.5 & 0.5 & 0.8 & 0.5 & 0.5 & 0.5 & 0.5 & 0.6 & 0.6 & 0.6 \\
\hline Interest obligations & 2.2 & 2.3 & 2.3 & 2.2 & 1.9 & 2.5 & 2.7 & 2.6 & 2.4 & 2.1 \\
\hline Domestic & 1.9 & 2.0 & 2.0 & 1.9 & 1.6 & 2.3 & 2.4 & 2.4 & 2.2 & 1.8 \\
\hline External & 0.3 & 0.3 & 0.2 & 0.3 & 0.3 & 0.3 & 0.2 & 0.2 & 0.2 & 0.2 \\
\hline Subsidies and transfers & 12.0 & 11.1 & 12.4 & 18.0 & 9.7 & 7.6 & 7.0 & 6.2 & 4.6 & 4.6 \\
\hline Subsidies & 8.9 & 8.2 & 9.5 & 14.6 & 6.5 & 3.7 & 2.8 & 1.7 & 0.0 & 0.0 \\
\hline \multicolumn{11}{|l|}{ Of which: } \\
\hline Petroleum products (including LPG) & 8.7 & 8.1 & 9.3 & 14.5 & 5.9 & 3.6 & 2.7 & 1.6 & 0.0 & 0.0 \\
\hline Electricity & 0.2 & 0.2 & 0.1 & 0.1 & 0.1 & 0.1 & 0.1 & 0.1 & 0.0 & 0.0 \\
\hline Transfers & 3.1 & 2.9 & 2.9 & 3.5 & 3.3 & 3.9 & 4.2 & 4.5 & 4.6 & 4.6 \\
\hline Of which: social welfare fund & 0.7 & 0.7 & 0.7 & 1.1 & $\ldots$ & 1.6 & 1.9 & 2.2 & 2.3 & 2.3 \\
\hline Other & 0.6 & 1.0 & 1.2 & 0.5 & 0.5 & 0.5 & 0.5 & 0.5 & 0.5 & 0.5 \\
\hline Capital expenditure & 7.9 & 7.3 & 7.2 & 7.1 & 7.2 & 6.0 & 6.0 & 6.4 & 6.8 & 7.0 \\
\hline Of which: foreign financed & $\ldots$ & $\ldots$ & 1.4 & 1.2 & 2.8 & 1.9 & 2.0 & 2.2 & 2.3 & 2.3 \\
\hline Net lending & 2.0 & 1.8 & 1.8 & 1.3 & 1.6 & 1.0 & 1.0 & 0.9 & 0.9 & 0.9 \\
\hline Overall balance (commitment) & -1.8 & 1.2 & -7.2 & -5.6 & -8.6 & -5.7 & -4.8 & -2.8 & -2.0 & -2.2 \\
\hline Discrepancy & 1.2 & -1.9 & 1.4 & 0.0 & 0.0 & 0.0 & 0.0 & 0.0 & 0.0 & 0.0 \\
\hline Financing & 0.6 & 0.7 & 5.8 & 5.6 & 8.6 & 5.7 & 4.8 & 2.8 & 2.0 & 2.2 \\
\hline External & 0.4 & 1.4 & 1.1 & 0.7 & 0.9 & 1.2 & 1.4 & 1.3 & 1.3 & 1.3 \\
\hline Domestic & 0.2 & -0.7 & 4.7 & 4.9 & 7.7 & 4.5 & 3.4 & 1.4 & 0.6 & 0.9 \\
\hline \multicolumn{11}{|l|}{ Memorandum items: } \\
\hline Overall balance (cash), excluding grants and & & & & & & & & & & \\
\hline foreign-financed capital expenditure $3 /$ & $\ldots$ & $\ldots$ & -4.7 & -4.8 & $\ldots$ & -4.6 & -3.3 & -1.1 & -0.3 & -0.5 \\
\hline Primary balance (cash) $3 /$ & 1.5 & 1.6 & -3.5 & -3.4 & $\ldots$ & -3.2 & -2.2 & -0.1 & 0.4 & -0.1 \\
\hline Non-hydrocarbon primary balance (cash) $3 /$ & -24.7 & -27.2 & -26.1 & -30.9 & $\cdots$ & -17.6 & -16.4 & -13.3 & -11.5 & -11.4 \\
\hline Non-hydrocarbon primary balance (cash), excluding & & & & & & & & & & \\
\hline grants and foreign-financed capital expenditure $3 /$ & $\ldots$ & $\ldots$ & -24.7 & -29.8 & $\ldots$ & -15.8 & -14.4 & -11.1 & -9.2 & -9.1 \\
\hline Defense spending & 4.9 & 5.6 & $\ldots$ & $\ldots$ & $\cdots$ & 5.6 & 5.6 & 5.6 & 5.6 & 5.6 \\
\hline Social spending $4 /$ & 7.4 & 7.4 & $\ldots$ & $\cdots$ & $\cdots$ & 8.4 & 8.7 & 9.0 & 9.1 & 9.1 \\
\hline Gross public debt $5 /$ & 43.8 & 40.8 & 40.4 & 38.1 & $\ldots$ & 41.1 & 38.7 & 36.1 & 33.6 & 32.6 \\
\hline Net public debt $5 /$ & 37.1 & 33.0 & 35.2 & 33.9 & $\cdots$ & 37.2 & 35.4 & 33.3 & 31.1 & 30.4 \\
\hline
\end{tabular}

Sources: Ministry of Finance; Ministry of Planning; and Fund staff estimates.

1/ The 2009 budget estimates are based on the Yemeni authorities' oil price (US $\$ 55 /$ barrel) and volume assumptions

2/ The 2009 budgeted wage bill is based on the original 2008 budget figure. Staff estimates also include a one-month Ramadan bonus and account for the wage increases announced in March 2008.

3/ Based on overall (cash) balance and statistical discrepancy, with relevant exclusions.

4/ Consists of education, health, social assistance, and social welfare fund transfers; covers central and local government units.

5 / Refers to central and local governments. 
Table 4. Republic of Yemen: Monetary Survey, 2005-09

(In millions of Yemeni rials)

\begin{tabular}{|c|c|c|c|c|c|}
\hline & $\begin{array}{c}2005 \\
\text { Dec. }\end{array}$ & $\begin{array}{c}2006 \\
\text { Dec. }\end{array}$ & $\begin{array}{l}2007 \\
\text { Dec. }\end{array}$ & $\begin{array}{l}2008 \\
\text { Dec. } \\
\text { Proj. }\end{array}$ & $\begin{array}{l}2009 \\
\text { Dec. } \\
\text { Proj. }\end{array}$ \\
\hline Net foreign assets & $1,271,390$ & $1,675,068$ & $1,733,844$ & $1,776,212$ & $1,737,275$ \\
\hline Central Bank of Yemen & $1,112,629$ & $1,419,174$ & $1,483,230$ & $1,525,234$ & $1,486,045$ \\
\hline Commercial banks & 158,761 & 255,894 & 250,614 & 250,979 & 251,230 \\
\hline Net domestic assets & $-221,881$ & $-323,638$ & $-147,623$ & 189,682 & 502,882 \\
\hline Net domestic credit & 132,511 & 117,508 & 376,518 & 728,208 & $1,042,688$ \\
\hline Net claims on central government & $-34,944$ & $-88,825$ & 66,936 & 241,748 & 454,882 \\
\hline Central Bank of Yemen & $-215,066$ & $-291,442$ & $-222,191$ & $-99,582$ & $-13,449$ \\
\hline Commercial banks & 180,123 & 202,617 & 289,128 & 341,331 & 468,331 \\
\hline Net claims on nongovernment enterprises & 167,455 & 206,333 & 309,582 & 486,460 & 587,806 \\
\hline Claims on private sector by commercial banks & 222,648 & 259,940 & 352,622 & 433,726 & 546,017 \\
\hline Claims on public enterprises $1 /$ & 43 & 3,063 & 15,220 & 100,000 & 80,000 \\
\hline Claims on mixed enterprises & 3,135 & 6,179 & 6,855 & 7,850 & 8,905 \\
\hline Pension fund deposits in CBY & $-57,772$ & $-62,349$ & $-65,116$ & $-55,116$ & $-47,116$ \\
\hline CBY certificates of deposit held in nonbanks. & -600 & -500 & 0 & 0 & 0 \\
\hline Other Items (net) & $-354,392$ & $-441,146$ & $-524,141$ & $-538,526$ & $-539,806$ \\
\hline Valuation adjustment & $-152,579$ & $-203,746$ & $-234,442$ & $-234,442$ & $-234,442$ \\
\hline Capital and reserves & $-60,640$ & $-83,590$ & $-112,896$ & $-139,061$ & $-149,142$ \\
\hline Other (net) & $-141,173$ & $-153,811$ & $-176,803$ & $-165,023$ & $-156,222$ \\
\hline Broad Money & $1,049,509$ & $1,351,430$ & $1,586,221$ & $1,965,894$ & $2,240,156$ \\
\hline Money & 442,464 & 558,461 & 613,748 & 707,722 & 806,456 \\
\hline Currency outside banks & 330,620 & 412,520 & 425,840 & 481,251 & 532,261 \\
\hline Demand deposits & 111,844 & 145,941 & 187,908 & 226,471 & 274,195 \\
\hline Quasi-money & 251,531 & 338,761 & 456,190 & 648,745 & 761,653 \\
\hline Foreign currency deposits & 355,514 & 454,209 & 516,284 & 609,427 & 672,047 \\
\hline \multicolumn{6}{|l|}{ Memorandum items: } \\
\hline Broad money (annual percentage change) & 14.4 & 28.8 & 17.4 & 23.9 & 14.0 \\
\hline Reserve money (annual percentage change) & 17.8 & 17.1 & 11.3 & 15.6 & 11.4 \\
\hline Credit to private sector (annual percentage change) & 21.3 & 16.7 & 35.7 & 23.0 & 25.9 \\
\hline Currency to broad money (in percent) & 31.5 & 30.5 & 26.8 & 24.5 & 23.8 \\
\hline Foreign currency deposits to total deposits & 49.5 & 48.4 & 44.5 & 41.0 & 39.3 \\
\hline Non-oil GDP velocity (average) & 2.1 & 2.0 & 2.0 & 2.0 & 2.1 \\
\hline Central Bank own gross foreign assets (US\$ millions) 2/ & 5,338 & 6,798 & 6,969 & 7,016 & 6,697 \\
\hline
\end{tabular}

Sources: Central Bank of Yemen and Fund staff estimates.

1/ The increase in credit to public enterprises reflects primarily a new revolving credit line to finance the importation of refined fuel products. 2/ Gross reserves minus commercial bank and pension fund foreign exchange deposits held with the Central Bank. 
Table 5. Republic of Yemen: Balance of Payments, 2005-13 (In millions of U.S. dollars)

\begin{tabular}{|c|c|c|c|c|c|c|c|c|c|}
\hline & \multirow[b]{2}{*}{2005} & \multirow[b]{2}{*}{2006} & \multirow{2}{*}{$\begin{array}{l}\text { Prel. } \\
2007\end{array}$} & \multicolumn{6}{|c|}{ Proj. } \\
\hline & & & & 2008 & 2009 & 2010 & 2011 & 2012 & 2013 \\
\hline Current account & 633 & 206 & $-1,507$ & -531 & -690 & -414 & -582 & -882 & -732 \\
\hline Non-hydrocarbon current account 1/ & $-3,128$ & $-3,721$ & $-4,499$ & $-5,257$ & $-4,282$ & $-4,982$ & $-5,331$ & $-5,610$ & $-5,491$ \\
\hline Goods and services & 840 & 84 & $-1,583$ & 125 & -496 & 21 & -238 & -761 & $-1,123$ \\
\hline Trade balance & 1,700 & 1,390 & -440 & 1,155 & 596 & 1,171 & 930 & 462 & 136 \\
\hline Exports, f.o.b. & 6,413 & 7,316 & 7,050 & 8,628 & 6,312 & 7,441 & 7,752 & 7,802 & 7,832 \\
\hline Hydrocarbon exports & 5,952 & 6,733 & 6,264 & 7,771 & 5,395 & 6,461 & 6,693 & 6,637 & 6,527 \\
\hline Non-hydrocarbon exports & 461 & 583 & 786 & 856 & 916 & 981 & 1,059 & 1,165 & 1,305 \\
\hline Imports, f.o.b. & 4,713 & 5,926 & 7,490 & 7,473 & 5,716 & 6,271 & 6,822 & 7,340 & 7,696 \\
\hline Hydrocarbon sector imports & 1,750 & 3,375 & 3,914 & 3,621 & 2,302 & 2,524 & 2,842 & 3,111 & 3,115 \\
\hline Other imports, f.o.b. & 2,963 & 2,551 & 3,576 & 3,852 & 3,414 & 3,747 & 3,980 & 4,229 & 4,580 \\
\hline Services, net & -860 & $-1,306$ & $-1,143$ & $-1,030$ & $-1,092$ & $-1,149$ & $-1,167$ & $-1,223$ & $-1,259$ \\
\hline Income, of which: & $-1,612$ & $-1,234$ & $-1,350$ & $-2,138$ & $-1,492$ & $-1,654$ & $-1,714$ & $-1,729$ & $-1,595$ \\
\hline Hydrocarbon company profits & $-1,525$ & $-1,365$ & $-1,352$ & $-2,074$ & $-1,402$ & $-1,699$ & $-1,758$ & $-1,732$ & $-1,606$ \\
\hline Current transfers & 1,406 & 1,356 & 1,426 & 1,482 & 1,298 & 1,218 & 1,369 & 1,609 & 1,986 \\
\hline Workers' remittances, net & 1,246 & 1,242 & 1,281 & 1,376 & 1,071 & 1,061 & 1,167 & 1,307 & 1,386 \\
\hline Capital \& financial account & -124 & 710 & 1,320 & 781 & 526 & 170 & 149 & 294 & 291 \\
\hline Direct investment, net, of which & -302 & 1,121 & 1,152 & 463 & 129 & -329 & -388 & -316 & -364 \\
\hline LNG sector & 0 & 1,200 & 1,785 & 875 & 115 & -189 & -189 & -193 & -328 \\
\hline Medium- and long-term loans, net & 111 & 236 & 238 & 176 & 338 & 499 & 537 & 609 & 655 \\
\hline New disbursements & 271 & 349 & 355 & 316 & 487 & 669 & 727 & 813 & 877 \\
\hline Amortization & 160 & 113 & 117 & 140 & 149 & 171 & 190 & 203 & 222 \\
\hline Commercial banks, net & 22 & -475 & 33 & 154 & 40 & 0 & 0 & 0 & 0 \\
\hline Others, net & 45 & -172 & -102 & -12 & 19 & 0 & 0 & 0 & 0 \\
\hline Errors and omissions & -181 & 536 & 482 & 0 & 0 & 0 & 0 & 0 & 0 \\
\hline Overall balance & 328 & 1,452 & 296 & 251 & -164 & -245 & -433 & -588 & -441 \\
\hline \multicolumn{10}{|l|}{ Financing } \\
\hline Central Bank net foreign assets (- increase) & -508 & $-1,462$ & -304 & -270 & 159 & 242 & 431 & 586 & 439 \\
\hline Exceptional Financing & 180 & 10 & 8 & 19 & 6 & 2 & 2 & 2 & 2 \\
\hline Financing gap (+ deficit) & 0 & 0 & 0 & 0 & 0 & 0 & 0 & 0 & 0 \\
\hline \multicolumn{10}{|l|}{ Memorandum items: } \\
\hline Current account including grants (percent of GDP) & 3.8 & 1.1 & -7.0 & -2.0 & -2.4 & -1.2 & -1.5 & -1.9 & -1.5 \\
\hline Non-hydrocarbon current account (percent of GDP) & -18.7 & -19.5 & -20.8 & -19.8 & -15.0 & -14.4 & -13.3 & -12.3 & -11.1 \\
\hline Central bank own gross foreign reserves $2 /$ & 5,338 & 6,798 & 6,969 & 7,016 & 6,697 & 6,427 & 5,971 & 5,385 & 4,946 \\
\hline (months of imports) $3 /$ & 11.6 & 10.0 & 10.2 & 13.3 & 10.3 & 9.4 & 8.5 & 7.5 & 6.5 \\
\hline Total External Debt (percent of GDP) 4/ & 30.9 & 28.7 & 26.9 & 22.3 & 21.8 & 19.4 & 18.0 & 17.1 & 17.2 \\
\hline Export oil price (US\$/barrel) & 51.5 & 63.0 & 72.3 & 96.0 & 52.8 & 63.3 & 69.8 & 73.5 & 76.0 \\
\hline Non-hydrocarbon export (growth) & 23.8 & 26.4 & 34.8 & 9.0 & 7.0 & 7.0 & 8.0 & 10.0 & 12.0 \\
\hline Imports (growth) & 22.1 & 25.7 & 26.4 & -0.2 & -23.5 & 9.7 & 8.8 & 7.6 & 4.8 \\
\hline
\end{tabular}

Sources: Central Bank of Yemen; and Fund staff estimates and projections.

1/ Hydrocarbon sector includes oil and LNG exports less corresonding imports, expenses and repatriation.

2/ Includes central bank SDR holdings, foreign exchange held abroad, foreign securities, gold, silver and foreign currencies; excludes commercial bank required foreign exchange reserves with the central bank against their foreign currency deposits and pension fund reserves. 3/ Imports are c.i.f. for next year and exclude oil sector imports.

4/ Public external debt, including central bank foreign liabilities. There is limited information on private external debt, which is deemed to be modest. 
Table 6. Republic of Yemen: Millennium Development Goals, 1990-06

\begin{tabular}{|c|c|c|c|c|c|c|c|c|c|}
\hline & 1990 & 1995 & 2000 & 2001 & 2002 & 2003 & 2004 & 2005 & 2006 \\
\hline \multicolumn{10}{|l|}{ 1. Eradicate extreme poverty and hunger } \\
\hline Population below U.S.\$1 a day (percent) & $\ldots$ & $\ldots$ & $\ldots$ & $\ldots$ & $\ldots$ & 15.7 & $\ldots$ & $\ldots$ & $\ldots$ \\
\hline Poverty gap ratio at $\$ 1$ a day (percent) & $\ldots$ & $\ldots$ & $\ldots$ & $\ldots$ & $\ldots$ & $\ldots$ & $\ldots$ & $\ldots$ & $\ldots$ \\
\hline Percentage share of income or consumption held by poorest 20 percent & $\ldots$ & $\ldots$ & $\ldots$ & $\ldots$ & $\ldots$ & $\ldots$ & $\ldots$ & $\ldots$ & $\ldots$ \\
\hline Prevalence of child malnutrition (percent of children under 5 ) & $\ldots$ & $\ldots$ & $\ldots$ & $\ldots$ & $\ldots$ & 45.6 & $\ldots$ & $\ldots$ & $\ldots$ \\
\hline Population below minimum level of dietary energy consumption (percent) & $\cdots$ & $\cdots$ & 33.0 & $\cdots$ & $\cdots$ & 36.0 & $\ldots$ & $\cdots$ & $\ldots$ \\
\hline \multicolumn{10}{|l|}{ 2. Achieve universal primary education } \\
\hline Net primary enrollment ratio (percent of relevant age group) & 51.7 & $\ldots$ & 59.7 & 67.7 & 65.0 & 73.1 & 75.3 & $\ldots$ & $\ldots$ \\
\hline Percentage of cohort reaching grade 5 (percent) & $\ldots$ & $\ldots$ & 74.5 & 74.5 & 75.9 & 73.2 & $\ldots$ & $\ldots$ & $\ldots$ \\
\hline Youth literacy rate (percent ages 15-24) & 50.0 & $\ldots$ & $\ldots$ & $\ldots$ & 67.9 & $\ldots$ & $\ldots$ & $\ldots$ & $\ldots$ \\
\hline \multicolumn{10}{|l|}{ 3. Promote gender equality } \\
\hline Ratio of girls to boys in primary education (percent) & 35.0 & $\ldots$ & 54.0 & 54.0 & $\ldots$ & 59.0 & 61.4 & $\ldots$ & 66.0 \\
\hline Ratio of girls to boys in secondary education (percent) & $\ldots$ & $\ldots$ & 42.0 & $\ldots$ & $\ldots$ & 60.0 & $\ldots$ & $\ldots$ & 66.0 \\
\hline Share of women employed in the nonagricultural sector (percent) & 8.9 & 7.6 & 6.3 & $\ldots$ & 5.8 & 6.1 & $\ldots$ & $\ldots$ & $\ldots$ \\
\hline Proportion of seats held by women in national parliament (percent) & 4.0 & 1.0 & 1.0 & $\ldots$ & 1.0 & 0.3 & $\ldots$ & 0.3 & 0.0 \\
\hline \multicolumn{10}{|l|}{ 4. Reduce child mortality } \\
\hline Under 5 mortality rate (per 1,000 ) & 142 & 126 & 117 & $\ldots$ & 114 & 113 & 113 & $\ldots$ & 100 \\
\hline Infant mortality rate $0-1$ year (per 1,000 live births) & 98 & 89 & 84 & $\ldots$ & 83 & $\ldots$ & $\ldots$ & 76 & 75 \\
\hline Immunization, measles (percent of children under 1 year old) & 69 & 46 & 71 & 79 & 65 & 66 & 76 & 76 & 80 \\
\hline \multicolumn{10}{|l|}{ 5. Improve maternal health } \\
\hline Maternal mortality ratio (per 100,000 live births) & 1,400 & 1,471 & 570 & $\ldots$ & $\ldots$ & $\ldots$ & $\ldots$ & $\ldots$ & $\ldots$ \\
\hline Births attended by skilled health staff & $\ldots$ & $\ldots$ & $\ldots$ & $\ldots$ & $\ldots$ & 26.8 & $\ldots$ & $\ldots$ & $\ldots$ \\
\hline \multicolumn{10}{|l|}{ 6. Combat HIVIAIDS, malaria and other diseases } \\
\hline Prevalence of HIV (percent ages 15-49) & $\ldots$ & $\ldots$ & $\ldots$ & $\ldots$ & $\ldots$ & 0.1 & 0.1 & $\ldots$ & $\ldots$ \\
\hline Contraceptive prevalence rate (percent of women ages 15-49) & $\ldots$ & $\ldots$ & $\ldots$ & $\ldots$ & $\ldots$ & 23.0 & 23.0 & $\ldots$ & $\ldots$ \\
\hline Number of children orphaned by HIVIAIDS & $\ldots$ & $\ldots$ & $\ldots$ & $\ldots$ & $\ldots$ & $\ldots$ & $\ldots$ & $\ldots$ & $\ldots$ \\
\hline Tuberculosis prevalence rate (per 100,000 people) & $\ldots$ & $\ldots$ & 102.0 & 99.0 & 95.0 & 91.0 & 86.0 & 82.0 & $\ldots$ \\
\hline \multicolumn{10}{|l|}{ 7. Ensure environmental sustainability } \\
\hline Forest area (percent of total land area) & 1.0 & $\ldots$ & 0.9 & $\ldots$ & $\ldots$ & $\ldots$ & $\ldots$ & 1.0 & $\ldots$ \\
\hline Nationally protected areas (percent of total land area) & $\ldots$ & $\ldots$ & & $\ldots$ & $\ldots$ & $\ldots$ & $\ldots$ & $\ldots$ & $\ldots$ \\
\hline GDP per unit of energy use (PPP U.S.\$ per kg oil equivalent) & $\ldots$ & $\ldots$ & 2.9 & 2.7 & 2.9 & 3.0 & 2.8 & $\ldots$ & $\ldots$ \\
\hline $\mathrm{CO} 2$ emissions (metric tons per capita) & $\ldots$ & 0.7 & 0.5 & $\ldots$ & 0.7 & $\ldots$ & $\ldots$ & $\ldots$ & $\ldots$ \\
\hline Access to an improved water source (percent of population) & 69.0 & $\ldots$ & $\ldots$ & $\ldots$ & 69.0 & 69.0 & 67.0 & $\ldots$ & 66.0 \\
\hline Access to improved sanitation (percent of population) & 21.0 & $\ldots$ & $\ldots$ & $\ldots$ & 30.0 & 30.0 & 43.0 & $\ldots$ & 88.0 \\
\hline Access to secure tenure (percent of population) & $\cdots$ & $\cdots$ & $\cdots$ & $\cdots$ & $\cdots$ & $\cdots$ & $\cdots$ & $\cdots$ & $\cdots$ \\
\hline \multicolumn{10}{|l|}{ 8. Develop a global partnership for development } \\
\hline Youth unemployment rate (percent of total labor force ages $15-24$ ) & $\ldots$ & $\ldots$ & $\ldots$ & $\ldots$ & $\ldots$ & $\ldots$ & $\ldots$ & $\ldots$ & $\ldots$ \\
\hline Fixed line and mobile telephones (per 100 people) & 1.1 & 1.3 & 2.1 & 2.0 & 7.6 & 10.2 & 14.8 & $\ldots$ & $\ldots$ \\
\hline Personal computers (per 100 people) & $\cdots$ & $\ldots$ & 0.2 & $\cdots$ & 0.7 & 0.7 & 0.8 & $\cdots$ & $\cdots$ \\
\hline \multicolumn{10}{|l|}{ General indicators } \\
\hline Adult literacy rate (percent of people ages 15 and over) & $\ldots$ & 40.0 & 46.0 & $\ldots$ & $\ldots$ & 49.0 & $\ldots$ & $\ldots$ & $\ldots$ \\
\hline Total fertility rate (births per woman) & $\ldots$ & 6.7 & 6.5 & $\ldots$ & 6.2 & 6.0 & $\ldots$ & 5.9 & 5.6 \\
\hline Life expectancy at birth (years) & $\ldots$ & 53.0 & 59.3 & $\ldots$ & 60.3 & $\ldots$ & $\ldots$ & 61.7 & 62.0 \\
\hline Aid per capita (current US\$) & $\ldots$ & $\ldots$ & 14.6 & 24.7 & 30.5 & 11.9 & 12.5 & 16.0 & 13.0 \\
\hline
\end{tabular}

Sources: World Bank; and Yemeni authorities. 


\title{
INTERNATIONAL MONETARY FUND
}

\section{REPUBLIC OF YEMEN}

\section{Joint World Bank/IMF Debt Sustainability Analysis}

\author{
Prepared by the Staffs of the International Monetary Fund and \\ the International Development Association
}

Approved by Adam Bennett and David Marston (IMF) and Carlos A. Primo Braga and Ritva Reinikka (IDA)

January 21, 2009

The Joint IMF-World Bank low-income country debt sustainability analysis (DSA) undertaken here reconfirms last year's assessment that Yemen is at a high risk of external debt distress. Even under a baseline scenario that assumes considerable adjustment, the present value $(P V)$ of debt-to-exports ratio breaches the sustainability threshold. Additional thresholds are breached under sensitivity tests. It will be critical for Yemen to maintain sound policies consistent with a prudent borrowing strategy.

\section{INTRODUCTION}

1. This joint Bank-Fund debt sustainability analysis (DSA) suggests that Yemen remains at a high risk of (external) debt distress. Current debt ratios are relatively low compared with the indicative thresholds for sustainability, but dwindling oil production over the medium term presents significant challenges. With unchanged policies, debt would quickly become unsustainable. Even under a baseline scenario that assumes comprehensive fiscal and structural reforms, one of the debt thresholds (PV of debt-to-exports ratio) is breached and two other indicators (PV of debt-to-GDP ratio and debt service-to-exports ratio) approach their respective threshold levels. Standard DSA stress tests highlight that external debt sustainability could be further weakened by adverse shocks, notably depreciation of the exchange rate, lower export growth, and less favorable financing terms. Strong fiscal and structural reforms, supported by concessional external financing, will thus be essential to avoid debt distress.

\section{The Yemeni authorities largely agreed with the staff analysis, but expressed} some reservations about the "high risk" assessment given that current debt ratios are low relative to the indicative thresholds. The staff emphasized the recent decline in economic performance (as manifest in the fiscal and external current account deficits), the forward-looking nature of the DSA, and the many risks to the macroeconomic framework and debt indicators over the medium and long term. In addition to the high vulnerability to adverse developments highlighted by the stress tests, the staff also underscored that the baseline macroeconomic framework assumed an ambitious reform and policy adjustment 
program, the achievement of which would require a serious and sustained level of commitment and continued external support.

\section{Methodology}

3. The DSA uses the debt sustainability framework for low-income countries. Debt sustainability is assessed in relation to policy-dependent thresholds for external debt burden indicators. According to the average Country Policy and Institutional Assessment index for 2007, Yemen is classified as a weak performer in terms of policies and institutions. ${ }^{1}$

4. The DSA is based on the macroeconomic framework discussed with the authorities during the 2008 IMF Article IV Consultations (IMF Country Report No.09/---). It assumes a sustained, front-loaded fiscal adjustment based on expenditure and revenue reforms in response to dwindling oil production. Beyond the medium term, it is assumed that the reform process would continue and intensify before and after the exhaustion of oil reservesprojected to occur around 2021. The outcome under this scenario is subjected to stress tests to assess its vulnerability to less favorable developments in key economic variables, including the macroeconomic consequences of maintaining current policies (a "nonadjustment" scenario).

\section{BACKGROUND}

5. This DSA updates the 2007 DSA (IMF Country Report No. 07/334 Supp.2); it incorporates more recent macroeconomic data including on the Liquefied Natural Gas (LNG) project, which is expected to begin production and export in 2009 and boost significantly overall hydrocarbon output. The outlook also incorporates the most recent information on and domestic oil reserves and production, actual 2007 debt data, and recent WEO projections of key economic variables, including international oil prices. The risk rating remains unchanged from the DSA prepared in 2007.

\section{A. The Current Situation}

\section{After three years of continuous decline, Yemen's net public debt to GDP}

increased moderately in 2007. This was mainly on account of an increase in the primary fiscal deficit by over 8 percent of GDP, and the impact of debt-to-GDP ratio would have been higher had it not been for relatively high nominal GDP growth. Net public debt (domestic and external) increased from 33 percent of GDP in 2006 to 35.2 percent in 2007. The 2007 fiscal deficit (5.8 percent of GDP; cash basis) was financed mainly by drawing down government deposits at the central bank (by 1.7 percent of GDP, to 5.2 percent of GDP), and by borrowing from the domestic bank and non-bank sectors (which increased the

\footnotetext{
${ }^{1}$ For a weak performer, the indicative thresholds for external debt sustainability are an PV of debt-to-exports ratio of 100 percent, and PV of debt-to-GDP ratio of 30 percent, and PV of debt-to-revenue ratio of 200 percent, a debt service-to-exports ratio of 15 percent, and a debt service-to-revenue ratio of 25 percent.
} 
gross stock of domestic debt by 1.5 percentage points to 13.5 percent of GDP). Although the external current account deteriorated sharply in 2007, this mainly reflected capital good imports related to the LNG project-financed by FDI. Consequently, external debt declined by about 2 percent of GDP.

\section{All external debt is owed to} Republic of Yemen: Composition of Total Public Debt, End-2007

official creditors, and is mostly on concessional terms. At end-2007, external debt amounted to $\$ 5.8$ billion, equivalent to 26.9 percent of GDP. Just over half of this debt was owed to multilateral creditors (including \$2.1 billion owed to the World Bank, \$0.6 billion owed to the Arab Fund for Social and Economic Development (AFESD), and \$170 million outstanding to the IMF), and the other half was owed to bilateral creditors (of which $\$ 1.2$ billion to Russia, $\$ 0.3$ billion to Saudi Arabia and \$240 million to Japan). Yemen benefited from a series of rescheduling arrangements under the Paris Club in 1996, 1997 and 2001. Bilateral agreements under these arrangements have been reached with most of the concerned donors. In 2007, Japan forgave about $\$ 8$ million of debt owed by Yemen.

\section{Domestic debt consists mostly of Treasury bills, held by domestic bank and} non-bank investors. Non-securitized debt held by domestic banks has been declining and amounted to less than 13 percent of the total stock of domestic debt in 2007. Treasury bills are issued at 3, 6 and 12 months maturities; the weighted average yield was about 16 percent in 2007. Although the majority of T-bills are held by domestic non-bank investors, banks acquired two-thirds of net new issues in 2007, bringing their share of domestic debt from about one-third in 2006 to more than 40 percent in 2007.

\section{Yemen does not have access to international capital markets, but official donor support in the form of grants and concessional loans is expected to continue in the} medium and long-term. Donors pledged concessional loans of about $\$ 2$ billion (and grants of about $\$ 3$ billion) at the Consultative Group meeting in London in 2006. Despite some reported delays in translating these pledges into actual commitments, ${ }^{2}$ active efforts by the authorities to undertake an adjustment and reform program should help mobilize the remaining assistance. New loan agreements for about $\$ 350$ million were signed in 2007, and for about $\$ 160$ million in the first part of 2008 .

\footnotetext{
${ }^{2}$ Reportedly, about 65 percent of these pledges have translated into actual commitments following bilateral agreements with the donors, although actual disbursements have been slow. This partly reflects the normal lag in the implementation of projects, but the authorities also indicated some delays in coming to terms with individual donors.
} 


\section{B. Macroeconomic Assumptions}

10. This DSA assumes that the authorities respond to dwindling oil production and lower oil prices through strong macroeconomic policies and structural reforms that facilitate economic diversification and help maintain macroeconomic stability. The baseline macroeconomic framework (Box 1) assumes that real GDP grows by about 41/2 percent over the long term. Underlying this assumption is strong fiscal adjustment - based on enhanced revenue mobilization and containing recurrent expenditure-accompanied by increased exchange rate flexibility, an ongoing commitment to containing inflation, as well as structural reforms to improve the business environment and encourage investment. Under these assumptions, the non-interest current account balance is projected to register moderate deficits that would be financed largely by FDI. ${ }^{3}$

\section{DebT AnAlysis}

\section{A. Public Debt Sustainability}

11. Even under an ambitious (baseline) adjustment scenario, public debt indicators raise serious concerns about long-term debt sustainability. Net public debt currently stands at 35.2 percent of GDP, a potentially large ratio in view of the government's low revenue mobilization capacity (non-hydrocarbon revenue was only 10 percent of GDP in 2007, of which tax revenue was only 7 percent). Although fiscal adjustment would improve the debt-to-GDP ratio in the medium term, this ratio is projected to approach 50 percent in the long term with the expected decline in oil revenue. The PV of public debt stood at 25 percent of GDP and 75 percent of revenue in 2007. These indicators are expected to increase to almost 40 percent of GDP and over 170 percent of revenue by 2028 .

\section{Standard stress tests highlight Yemen's vulnerability to adverse economic} developments, such as a less favorable growth outturn or a weaker fiscal adjustment.

- If real GDP grew by 3.2 percent in 2009-10 (below baseline projections but close to actual growth rate of in 2006 and 2007), the PV of debt-to-GDP ratio would rise to about 65 percent and the PV of debt-to-revenue ratio would approach 300 percent by 2028.

\footnotetext{
${ }^{3}$ Net FDI are projected to turn into outflows in 2010 following the completion of a major LNG investment project, but are expected to become positive again in the medium-to-long term.
} 


\section{Box 1. Macroeconomic Assumptions for the Baseline (Adjustment) Scenario}

Given Yemen's high dependency on oil ${ }^{4}$ the adjustment scenario encompasses a range of policy and structural reforms to address the expected end of oil production by 2021. After crude oil production ceases, hydrocarbon revenues are projected to drop dramatically to about 16 percent of fiscal revenues (from LNG exports and domestic gas sales) and to 26 percent of total merchandise exports.

In the medium term (2009-13), real GDP growth is projected to average 5.2 percent, boosted by the start of LNG production in 2009. Reforms center on fiscal adjustment, with an average annual reduction in the non-oil primary deficit of 1.6 percent of GDP (after a larger reduction in 2009 due to lower oil prices). Key spending reforms include eliminating fuel subsidies by 2012, containing the civil service wage bill, better expenditure management, and increased (but better targeted) social spending, to protect the poor from the adverse effects of removing domestic fuel subsidies. Tax revenue would be enhanced by over 3 percentage points by:

implementing fully the General Sales Tax (doubling the rate from 5 percent to 10 percent in 2011); improving customs and tax administration; eliminating exemptions in the customs, income tax, and investment laws; and introducing a tax on petroleum products (2012). Even with declining oil exports, the current account deficit is expected to narrow from 7 percent of GDP in 2007 to 1.7 percent of GDP on average from 2009 to 2013.

The long term projections are based on the following policy assumptions:

- Moderate real GDP growth, averaging 4.3 percent from 2014 to 2028, with non-hydrocarbon growth close to 5 percent offsetting the decline in oil output. These assumptions are in line with the historical experience: the non-oil sector grew at an average rate of 5.2 percent during 1991-2007. Continued non-hydrocarbon growth will depend on sustained fiscal, financial sector, and structural reforms to improve the investment environment, and sizeable donor-funded public investment.

- Continued revenue mobilization efforts, notably through a further increase in the GST rate to 12 percent in 2014, and further strengthening of the tax and customs administration to improve the efficiency of both direct and indirect tax collection (GST, customs duties, excises on petroleum products, and income tax).

- Additional expenditure restraint - including a concerted effort to reduce the public wage bill to below 6 percent of GDP by 2028 - would also provide the fiscal space for the social welfare expenditures required to smooth the transition to a predominantly non-oil economy.

- A more flexible exchange rate arrangement, would allow the accumulation of external reserves that would be later used to smooth the impact of the end of oil production in 2021.

- Official creditors are expected to provide external financing on concessional terms over the projection period, as the loss of oil production will require continued reliance on concessional external assistance. Domestic financing is assumed to come from the bank and non-bank sectors at positive real interest rates.

Under these assumptions, the overall fiscal balance moves sharply into deficit with the loss of oil revenues (nearly $6 \frac{1}{2}$ percent of GDP in 2021), but improves thereafter as reforms take hold. The non-interest current account deficit, largely financed by foreign direct investment, widens to about 8 percent of GDP with the depletion of oil in 2021, but narrows thereafter, with a pick-up in non-oil exports (from a low base), fiscal moderation, and sustained inward remittances and official transfers.

\footnotetext{
${ }^{4}$ Hydrocarbon earnings account for about 75 percent of fiscal revenues and 90 percent of merchandise exports.
} 
- Permanently lower growth over the entire projection period by $1 / 4$ of a percentage point of GDP would result in a debt-to-GDP and debt-to-revenue ratio in excess of 50 percent and 225 percent, respectively, in 2028.

- If the primary deficit remained unchanged from the estimated 2008 level, by 2028 the debt-GDP ratio would approach 70 percent and the debt-revenue ratio would exceed 300 percent.

- An oil price $\$ 20$ below baseline projections in 2009 and 2010 would have a relatively modest impact on the debt sustainability indicators, reflecting the decline in domestic oil production and the shift to being a net oil importer.

\section{To highlight the critical need for reform and adjustment, debt dynamics were} also evaluated under unchanged policies (a non-adjustment scenario). Under such a scenario, public debt quickly becomes unsustainable. In the absence of structural reform and fiscal adjustment efforts, by 2018 the PV of public debt would exceed 100 percent of GDP and debt service would absorb about one-third of fiscal revenues. Beyond this, public debt would increase to such unsustainable levels so as to render a sharp (and potentially destabilizing) adjustment unavoidable.

\section{B. External Debt Sustainability}

\section{Under the baseline (adjustment) scenario, Yemen's external debt situation} entails a high risk of debt distress. Although all indicators are currently below the policydependent thresholds, the $\mathrm{PV}$ of debt-to-exports ratio is projected to rise above the 100 percent threshold by 2018 and the PV of debt-to-GDP ratio is projected to approach the 30 percent threshold by 2028 . While other indicators remain below their respective thresholds, the outlook is projected to worsen as debt accumulates and the resources available to service it decline as a result of the loss of oil exports around 2021.

15. This outcome is highly vulnerable to adverse shocks. Under stress tests, two of the indicators (PV of debt-to-GDP and PV of debt-to-exports) breach their respective thresholds while another two (PV of debt-to-revenues and debt service-to-exports) approach the threshold level. Debt indicators are most vulnerable to a depreciation in the exchange rate, lower export growth, and less favorable financing terms. A one-time 30 percent devaluation of the Yemeni rial in 2009 would bring the PV of debt above 40 percent of GDP and almost 200 percent of fiscal revenue by 2028. If export growth remained one standard deviation below its historical average in 2009 and 2010, the PV of debt would peak at 245 percent of exports by 2025 and exceed 130 percent of fiscal revenue by 2028 , and external debt service would rise above 10 percent of exports. If interest rates on new external borrowing were 2 percent higher than in the baseline, the PV of debt would peak above 240 percent of exports in 2025.

16. Under the non-adjustment scenario, external debt would also become rapidly unsustainable. Even assuming that financing would continue to be available on 
comparatively favorable (but not fully concessional) terms, all thresholds are breached fairly rapidly, and exceeded by a considerable margin in the medium term. Under these conditions, little room would be left to absorb the shocks associated with the end of oil production around 2021.

\section{CONCLuSION}

17. This DSA confirms the results of last year's DSA that Yemen remains at a high risk of debt distress. Despite relatively low debt ratios at present, the recent deterioration in macroeconomic performance and the medium-term challenges presented by declining oil production and volatility in oil prices present considerable risks. Even assuming an ambitious reform agenda, sound macroeconomic policies, and continued support from the donor community, Yemen will face a difficult path in coming years. This highlights the need for early action on key reforms to strengthen public finances, bolster debt management, and boost prospects for investment and growth. 
Table 1. Republic of Yemen: Public Sector Debt Sustainability Framework, Baseline Scenario, 2005-28

(In percent of GDP, unless otherwise indicated)

\begin{tabular}{|c|c|c|c|c|c|c|c|c|c|c|c|c|c|c|c|}
\hline & \multicolumn{3}{|c|}{ Actual } & \multirow[b]{2}{*}{ Average } & \multirow[b]{2}{*}{$\begin{array}{l}\text { Standard } \\
\text { Deviation }\end{array}$} & \multirow{2}{*}{$\frac{\text { Estimate }}{2008}$} & \multirow[b]{2}{*}{2009} & \multirow[b]{2}{*}{2010} & \multirow[b]{2}{*}{2011} & \multicolumn{3}{|c|}{ Projections } & \multirow[b]{2}{*}{2018} & \multirow[b]{2}{*}{2028} & \multirow[b]{2}{*}{$\begin{array}{l}2014-28 \\
\text { Average }\end{array}$} \\
\hline & 2005 & 2006 & 2007 & & & & & & & 2012 & 2013 & $\begin{array}{l}2008-13 \\
\text { Average }\end{array}$ & & & \\
\hline $\begin{array}{l}\text { Public sector debt } 1 / \\
\text { Of which: foreign-currency denominated }\end{array}$ & $\begin{array}{l}37.1 \\
30.9\end{array}$ & $\begin{array}{l}33.0 \\
28.7\end{array}$ & $\begin{array}{l}35.2 \\
26.9\end{array}$ & & & $\begin{array}{l}33.9 \\
22.3\end{array}$ & $\begin{array}{l}37.2 \\
21.8\end{array}$ & $\begin{array}{l}35.4 \\
19.4\end{array}$ & $\begin{array}{l}33.3 \\
18.0\end{array}$ & $\begin{array}{l}31.1 \\
17.1\end{array}$ & $\begin{array}{l}30.4 \\
17.2\end{array}$ & & $\begin{array}{l}31.5 \\
21.5\end{array}$ & $\begin{array}{l}48.7 \\
39.4\end{array}$ & \\
\hline $\begin{array}{l}\text { Change in public sector debt } \\
\text { Identified debt-creating flows }\end{array}$ & $\begin{array}{l}-8.4 \\
-6.7\end{array}$ & $\begin{array}{l}-4.1 \\
-7.2\end{array}$ & $\begin{array}{l}2.2 \\
1.8\end{array}$ & & & $\begin{array}{l}-1.3 \\
-1.7\end{array}$ & $\begin{array}{l}3.3 \\
2.8\end{array}$ & $\begin{array}{l}-1.8 \\
-2.2\end{array}$ & $\begin{array}{l}-2.2 \\
-2.5\end{array}$ & $\begin{array}{l}-2.1 \\
-2.5\end{array}$ & $\begin{array}{l}-0.7 \\
-1.0\end{array}$ & & $\begin{array}{l}0.6 \\
0.5\end{array}$ & $\begin{array}{l}-0.6 \\
-0.6\end{array}$ & \\
\hline Primary deficit & -0.7 & -3.6 & 4.9 & -1.1 & 4.3 & 3.4 & 3.2 & 2.2 & 0.1 & -0.4 & 0.1 & 1.4 & 1.3 & 0.5 & 1.9 \\
\hline Revenue and grants & 34.9 & 38.6 & 33.2 & & & 37.4 & 24.9 & 24.6 & 26.0 & 25.1 & 24.7 & & 24.1 & 22.4 & \\
\hline Of which: grants & 0.4 & 0.4 & 0.3 & & & 0.4 & 0.8 & 0.4 & 0.5 & 0.6 & 0.6 & & 0.9 & 0.9 & \\
\hline Primary (noninterest) expenditure & 34.2 & 35.0 & 38.0 & & & 40.8 & 28.1 & 26.8 & 26.1 & 24.7 & 24.8 & & 25.4 & 22.9 & \\
\hline Automatic debt dynamics & -6.0 & -3.6 & -3.0 & & & -5.1 & -0.3 & -4.3 & -2.6 & -2.0 & -1.1 & & -0.9 & -1.1 & \\
\hline Contribution from interest rate/growth differential & -2.9 & -1.4 & -1.2 & & & -1.5 & -0.8 & -1.9 & -1.1 & -0.9 & -0.9 & & -1.1 & -1.9 & \\
\hline Of which: contribution from average real interest rate & -0.5 & -0.3 & -0.1 & & & -0.2 & 1.7 & -0.2 & 0.4 & 0.5 & 0.4 & & 0.3 & 0.2 & \\
\hline Of which: contribution from real GDP growth & -2.4 & -1.1 & -1.1 & & & -1.3 & -2.4 & -1.8 & -1.5 & -1.4 & -1.4 & & -1.3 & -2.1 & \\
\hline Contribution from real exchange rate depreciation & -3.1 & -2.2 & -1.9 & & & -3.6 & 0.4 & -2.4 & -1.5 & -1.1 & -0.2 & & $\ldots$ & & \\
\hline Other identified debt-creating flows & 0.0 & 0.0 & 0.0 & & & 0.0 & 0.0 & 0.0 & 0.0 & 0.0 & 0.0 & & 0.0 & 0.0 & \\
\hline Privatization receipts (negative) & 0.0 & 0.0 & 0.0 & & & 0.0 & 0.0 & 0.0 & 0.0 & 0.0 & 0.0 & & 0.0 & 0.0 & \\
\hline Recognition of implicit or contingent liabilities & 0.0 & 0.0 & 0.0 & & & 0.0 & 0.0 & 0.0 & 0.0 & 0.0 & 0.0 & & 0.0 & 0.0 & \\
\hline Debt relief (HIPC and other) & 0.0 & 0.0 & 0.0 & & & 0.0 & 0.0 & 0.0 & 0.0 & 0.0 & 0.0 & & 0.0 & 0.0 & \\
\hline Other (specify, e.g. bank recapitalization) & 0.0 & 0.0 & 0.0 & & & 0.0 & 0.0 & 0.0 & 0.0 & 0.0 & 0.0 & & 0.0 & 0.0 & \\
\hline Residual, including asset changes & -1.7 & 3.1 & 0.4 & & & 0.5 & 0.4 & 0.4 & 0.3 & 0.3 & 0.3 & & 0.1 & 0.0 & \\
\hline \multicolumn{16}{|l|}{ Other Sustainability Indicators: } \\
\hline $\mathrm{PV}$ of public sector debt & $\ldots$ & $\ldots$ & 24.8 & & & 25.4 & 29.0 & 28.3 & 26.8 & 25.1 & 24.4 & & 24.7 & 37.9 & \\
\hline Of which: foreign-currency denominated & $\ldots$ & $\ldots$ & 16.5 & & & 13.8 & 13.7 & 12.2 & 11.5 & 11.0 & 11.1 & & 14.8 & 28.6 & \\
\hline Of which: external & $\ldots$ & $\ldots$ & 16.5 & & & 13.8 & 13.7 & 12.2 & 11.5 & 11.0 & 11.1 & & 14.8 & 28.6 & \\
\hline PV of contingent liabilities (not included in public sector debt) & & $\ldots$ & & & & $\ldots$ & $\ldots$ & $\ldots$ & $\ldots$ & $\ldots$ & $\ldots$ & & $\ldots$ & $\ldots$ & \\
\hline Gross financing need 2/ & 3.3 & -0.3 & 8.1 & & & 6.4 & 6.4 & 5.4 & 3.3 & 2.4 & 2.6 & & 3.0 & 2.8 & \\
\hline PV of public sector debt-to-revenue and grants ratio (in percent) & $\ldots$ & $\ldots$ & 74.6 & & & 68.0 & 116.5 & 115.0 & 103.1 & 99.6 & 98.7 & & 102.8 & 169.0 & \\
\hline $\mathrm{PV}$ of public sector debt-to-revenue ratio (in percent) & $\ldots$ & $\ldots$ & 75.4 & & & 68.6 & 120.2 & 117.0 & 105.1 & 102.2 & 101.1 & & 106.8 & 176.1 & \\
\hline Of which: external $3 /$ & & & 50.2 & & & 37.2 & 56.5 & 50.6 & 45.0 & 44.9 & 46.2 & & 63.7 & 133.0 & \\
\hline Debt service-to-revenue and grants ratio (in percent) 4 / & 11.4 & 8.4 & 9.9 & & & 8.0 & 12.9 & 13.2 & 12.3 & 11.4 & 10.2 & & 7.2 & 10.6 & \\
\hline Debt service-to-revenue ratio (in percent) $4 /$ & 11.6 & 8.5 & 10.0 & & & 8.1 & 13.3 & 13.5 & 12.6 & 11.7 & 10.4 & & 7.4 & 11.1 & \\
\hline Primary deficit that stabilizes the debt-to-GDP ratio & 7.7 & 0.5 & 2.6 & & & 4.7 & -0.1 & 3.9 & 2.3 & 1.7 & 0.8 & & 0.7 & 1.0 & \\
\hline \multicolumn{16}{|l|}{ Key macroeconomic and fiscal assumptions: } \\
\hline Real GDP growth (in percent) & 5.6 & 3.2 & 3.3 & 4.4 & 1.1 & 3.9 & 7.7 & 5.0 & 4.4 & 4.5 & 4.5 & 5.0 & 4.5 & 4.5 & 4.3 \\
\hline Average nominal interest rate on forex debt (in percent) & 2.0 & 1.3 & 1.2 & 1.2 & 0.4 & 1.4 & 1.3 & 1.4 & 1.5 & 1.5 & 1.6 & 1.4 & 1.7 & 1.9 & 1.8 \\
\hline Average real interest rate on domestic debt (in percent) & -0.9 & 5.0 & 7.7 & 1.1 & 10.0 & -1.0 & 15.7 & -0.2 & 3.1 & 4.1 & 3.8 & 4.2 & 3.6 & 2.9 & 3.5 \\
\hline Real exchange rate depreciation (in percent, + indicates depreciation) & -8.6 & -7.5 & -6.9 & -6.3 & 5.8 & -13.9 & & & & & & & & & \\
\hline Inflation rate (GDP deflator, in percent) & 18.5 & 13.6 & 10.9 & 13.1 & 12.5 & 18.6 & -0.4 & 15.5 & 11.0 & 9.2 & 8.4 & 10.4 & 6.1 & 6.9 & 6.4 \\
\hline Growth of real primary spending (deflated by GDP deflator, in percent) & 0.1 & 0.1 & 0.1 & 0.1 & 0.1 & 0.1 & -0.3 & 0.0 & 0.0 & 0.0 & 0.1 & 0.0 & 0.0 & 0.0 & 0.0 \\
\hline Grant element of new external borrowing (in percent) & 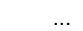 & $\ldots$ & $\ldots$ & $\ldots$ & $\ldots$ & 35.7 & 35.7 & 35.7 & 35.7 & 35.7 & 35.7 & 35.7 & 35.7 & 35.7 & ... \\
\hline
\end{tabular}

Sources: Yemeni authorities; and Fund staff estimates and projections.

1/ Public sector refers to the combined central and local government; public debt refers to net public debt.

2/ Gross financing need is defined as the primary deficit plus debt service plus the stock of short-term debt at the end of the last period.

$3 /$ Revenues excluding grants.

4/ Debt service is defined as the sum of interest and amortization of medium and long-term debt.

$5 /$ Historical averages and standard deviations are generally derived over the past 10 years, subject to data availability. 
Table 2. Republic of Yemen: Sensitivity Analysis for Key Indicators of Public Debt 2008-28

(in percent)

Projections

$\begin{array}{llllllll}2008 & 2009 & 2010 & 2011 & 2012 & 2013 & 2018 & 2028\end{array}$

PV of Debt-to-GDP Ratio

Baseline

A. Alternative scenarios

A1. Real GDP growth and primary balance are at historical averages

A2. Primary balance is unchanged from 2008

A3. Permanently lower GDP growth 1/

A4. Non-adjustment scenario

B. Bound tests

B1. Real GDP growth is at historical average minus one standard deviations in 2009-10

B2. Primary balance is at historical average minus one standard deviations in 2009-10

B3. Combination of B1-B2 using one half standard deviation shocks

B4. One-time 30 percent real depreciation in 2009

B5. 10 percent of GDP increase in other debt-creating flows in 2009

B6. Oil price $\$ 10$ below baseline projection in 2009-11.

PV of Debt-to-Revenue Ratio 2/

Baseline

A. Alternative scenarios

A1. Real GDP growth and primary balance are at historical averages

A2. Primary balance is unchanged from 2008

A3. Permanently lower GDP growth $1 /$

A4. Non-adjustment scenario

B. Bound tests

B1. Real GDP growth is at historical average minus one standard deviations in 2009-10

B2. Primary balance is at historical average minus one standard deviations in 2009-10

B3. Combination of B1-B2 using one half standard deviation shocks

B4. One-time 30 percent real depreciation in 2009

B5. 10 percent of GDP increase in other debt-creating flows in 2009

B6. Oil price $\$ 10$ below baseline projection in 2009-11.

Debt Service-to-Revenue Ratio 2/

Baseline

$\begin{array}{rrrrrrrr}25 & 29 & 28 & 27 & 25 & 24 & 25 & 38 \\ & & & & & & & \\ 25 & 26 & 23 & 20 & 18 & 17 & 8 & \ldots \\ 25 & 30 & 31 & 33 & 35 & 37 & 49 & 69 \\ 25 & 30 & 30 & 29 & 27 & 27 & 30 & 51 \\ 26 & 34 & 39 & 46 & 54 & 61 & 101 & 272 \\ & & & & & & & \\ 25 & 32 & 34 & 34 & 34 & 34 & 41 & 65 \\ 25 & 30 & 30 & 29 & 28 & 27 & 27 & 40 \\ 25 & 28 & 27 & 27 & 27 & 28 & 34 & 56 \\ 25 & 35 & 34 & 32 & 30 & 29 & 30 & 46 \\ 25 & 40 & 39 & 38 & 36 & 35 & 35 & 46 \\ 25 & 31 & 31 & 30 & 28 & 27 & 28 & 41\end{array}$

A. Alternative scenarios

A1. Real GDP growth and primary balance are at historical averages

A2. Primary balance is unchanged from 2008

A3. Permanently lower GDP growth 1/

A4. Non-adjustment scenario

$\begin{array}{llllllll}68 & 117 & 115 & 103 & 100 & 99 & 103 & 169\end{array}$

$\begin{array}{rrrrrrrr}68 & 105 & 93 & \ldots & \ldots & \ldots & \ldots & \ldots \\ 68 & 120 & 125 & 126 & 139 & 152 & 204 & 307 \\ 68 & 119 & 120 & 110 & 109 & 110 & 124 & 226\end{array}$

$\begin{array}{rrrrrrrr}68 & 119 & 120 & 110 & 109 & 110 & 124 & 226\end{array}$

$\begin{array}{llllllll}68 & 128 & 136 & 130 & 133 & 139 & 171 & 288\end{array}$

$\begin{array}{llllllll}68 & 119 & 123 & 112 & 109 & 109 & 113 & 177\end{array}$

$\begin{array}{llllllll}68 & 114 & 111 & 105 & 107 & 111 & 139 & 248\end{array}$

$\begin{array}{llllllll}68 & 141 & 138 & 123 & 119 & 119 & 123 & 206\end{array}$

$\begin{array}{llllllll}68 & 159 & 159 & 145 & 143 & 142 & 145 & 207\end{array}$

B. Bound tests

B1. Real GDP growth is at historical average minus one standard deviations in 2009-10

B2. Primary balance is at historical average minus one standard deviations in 2009-10

B3. Combination of B1-B2 using one half standard deviation shocks

B4. One-time 30 percent real depreciation in 2009

B5. 10 percent of GDP increase in other debt-creating flows in 2009

B6. Oil price $\$ 10$ below baseline projection in 2009-11.

\begin{tabular}{|c|c|c|c|c|c|c|}
\hline 8 & 13 & 13 & 12 & 11 & 10 & 7 \\
\hline 8 & 13 & 11 & $\ldots$ & $\ldots$ & $\ldots$ & $\ldots$ \\
\hline 8 & 13 & 13 & 14 & 17 & 25 & 50 \\
\hline 8 & 13 & 13 & 13 & 12 & 11 & 12 \\
\hline 8 & 13 & 16 & 20 & 26 & 27 & 33 \\
\hline 8 & 13 & 15 & 17 & 19 & 21 & 32 \\
\hline 8 & 13 & 13 & 13 & 15 & 11 & 10 \\
\hline 8 & 13 & 12 & 5 & 6 & 8 & 17 \\
\hline 8 & 14 & 15 & 14 & 14 & 13 & 13 \\
\hline 8 & 13 & 19 & 44 & 20 & 40 & 20 \\
\hline 8 & 15 & 15 & 14 & 13 & 11 & 8 \\
\hline
\end{tabular}

Sources: Yemeni authorities; and Fund staff estimates and projections.

1/ Assumes that real GDP growth is at baseline minus one standard deviation divided by the length of the projection period.

2/ Revenues are defined inclusive of grants. 
Table 3. Republic of Yemen: External Debt Sustainability Framework, Baseline Scenario, 2005-28 1/

(In percent of GDP, unless otherwise indicated)

\begin{tabular}{|c|c|c|c|c|c|c|c|c|c|c|c|c|c|c|c|}
\hline & \multicolumn{3}{|c|}{ Actual } & \multirow{2}{*}{$\begin{array}{l}\text { Historical } \\
\text { Average }\end{array}$} & \multirow{2}{*}{$\begin{array}{l}\text { Standard } \\
\text { Deviation }\end{array}$} & \multicolumn{6}{|c|}{ Projections } & \multirow[b]{2}{*}{$\begin{array}{l}2008-13 \\
\text { Average }\end{array}$} & \multirow[b]{2}{*}{2018} & \multirow[b]{2}{*}{2028} & \multirow[b]{2}{*}{$\begin{array}{l}2014-28 \\
\text { Average }\end{array}$} \\
\hline & 2005 & 2006 & 2007 & & & 2008 & 2009 & 2010 & 2011 & 2012 & 2013 & & & & \\
\hline External debt (nominal) $1 /$ & 30.9 & 28.7 & 26.9 & & & 22.3 & 21.8 & 19.4 & 18.0 & 17.1 & 17.2 & & 21.5 & 39.4 & \\
\hline Of which: public and publicly guaranteed (PPG) & 30.9 & 28.7 & 26.9 & & & 22.3 & 21.8 & 19.4 & 18.0 & 17.1 & 17.2 & & 21.5 & 39.4 & \\
\hline Change in external debt & -7.6 & -2.2 & -1.8 & & & -4.6 & -0.5 & -2.5 & -1.4 & -0.9 & 0.1 & & 1.0 & -0.5 & \\
\hline Identified net debt-creating flows & -8.6 & -10.7 & -1.8 & & & -0.6 & 0.4 & 1.2 & 1.7 & 1.9 & 1.5 & & 0.5 & -0.6 & \\
\hline Non-interest current account deficit & -4.4 & -1.4 & 6.7 & -4.2 & 5.7 & 1.7 & 2.2 & 0.9 & 1.2 & 1.7 & 1.2 & & 2.5 & 3.7 & 4.5 \\
\hline Deficit in balance of goods and services & -5.0 & -0.4 & 7.3 & & & -0.5 & 1.7 & -0.1 & 0.6 & 1.7 & 2.3 & & 5.7 & 7.6 & \\
\hline Exports & 40.9 & 41.3 & 35.9 & & & 35.6 & 24.7 & 23.9 & 21.7 & 19.4 & 18.2 & & 13.6 & 15.1 & \\
\hline Imports & 35.9 & 40.8 & 43.2 & & & 35.1 & 26.4 & 23.9 & 22.3 & 21.1 & 20.5 & & 19.2 & 22.7 & \\
\hline Net current transfers (negative $=$ inflow) & -8.4 & -7.1 & -6.6 & -12.4 & 4.9 & -5.6 & -4.6 & -3.5 & -3.4 & -3.5 & -4.0 & & -4.9 & -4.6 & -4.8 \\
\hline Of which: official & -0.9 & -0.6 & -0.7 & & & -0.4 & -0.8 & -0.5 & -0.5 & -0.7 & -0.6 & & -1.0 & -1.0 & \\
\hline Other current account flows (negative = net inflow) & 9.0 & 6.1 & 5.9 & & & 7.7 & 5.0 & 4.5 & 4.0 & 3.5 & 3.0 & & 1.7 & 0.7 & \\
\hline Net FDI (negative = inflow) & 1.8 & -5.9 & -5.3 & -0.4 & 3.4 & -1.7 & -0.5 & 1.0 & 1.0 & 0.7 & 0.7 & & -1.4 & -3.3 & -2.3 \\
\hline Endogenous debt dynamics $2 /$ & -5.9 & -3.4 & -3.1 & & & -0.6 & -1.3 & -0.7 & -0.5 & -0.5 & -0.5 & & -0.6 & -1.0 & \\
\hline Contribution from nominal interest rate & 0.6 & 0.4 & 0.3 & & & 0.3 & 0.3 & 0.3 & 0.2 & 0.2 & 0.2 & & 0.3 & 0.7 & \\
\hline Contribution from real GDP growth & -1.8 & -0.9 & -0.8 & & & -0.9 & -1.6 & -0.9 & -0.7 & -0.7 & -0.7 & & -0.9 & -1.7 & \\
\hline Contribution from price and exchange rate changes & -4.8 & -2.9 & -2.6 & & & & & & & & & & & & \\
\hline Residual (3-4) 31 & 1.0 & 8.5 & 0.0 & & & -4.0 & -0.8 & -3.7 & -3.1 & -2.8 & -1.4 & & 0.5 & 0.1 & \\
\hline Of which: exceptional financing & -1.1 & -0.1 & 0.0 & & & -0.1 & 0.0 & 0.0 & 0.0 & 0.0 & 0.0 & & 0.0 & 0.0 & \\
\hline PV of external debt $4 /$ & $\ldots$ & $\ldots$ & 16.5 & & & 13.8 & 13.7 & 12.2 & 11.5 & 11.0 & 11.1 & & 14.8 & 28.6 & \\
\hline In percent of exports & $\ldots$ & $\ldots$ & 45.9 & & & 38.7 & 55.3 & 51.1 & 52.8 & 56.7 & 61.2 & & 108.7 & 189.3 & \\
\hline PV of PPG external debt & $\ldots$ & $\ldots$ & 16.5 & & & 13.8 & 13.7 & 12.2 & 11.5 & 11.0 & 11.1 & & 14.8 & 28.6 & \\
\hline In percent of exports & $\ldots$ & $\ldots$ & 45.9 & & & 38.7 & 55.3 & 51.1 & 52.8 & 56.7 & 61.2 & & 108.7 & 189.3 & \\
\hline In percent of government revenues & & & 50.2 & & & 37.2 & 56.5 & 50.6 & 45.0 & 44.9 & 46.2 & & 63.7 & 133.0 & \\
\hline Debt service-to-exports ratio (in percent) & 5.2 & 2.9 & 3.5 & & & 3.1 & 3.9 & 3.5 & 3.6 & 3.5 & 3.8 & & 4.8 & 9.9 & \\
\hline PPG debt service-to-exports ratio (in percent) & 5.2 & 2.9 & 3.5 & & & 3.1 & 3.9 & 3.5 & 3.6 & 3.5 & 3.8 & & 4.8 & 9.9 & \\
\hline PPG debt service-to-revenue ratio (in percent) & 6.2 & 3.1 & 3.8 & & & 3.0 & 3.9 & 3.4 & 3.1 & 2.8 & 2.9 & & 2.8 & 7.0 & \\
\hline Total gross financing need & -0.1 & -1.2 & 0.6 & & & 0.3 & 0.8 & 0.9 & 1.2 & 1.4 & 1.3 & & 1.1 & 1.8 & \\
\hline Non-interest current account deficit that stabilizes debt ratio & 3.2 & 0.8 & 8.4 & & & 6.3 & 2.6 & 3.4 & 2.6 & 2.6 & 1.2 & & 1.5 & 4.2 & \\
\hline \multicolumn{16}{|l|}{ Key macroeconomic assumptions: } \\
\hline Real GDP growth (in percent) & 5.6 & 3.2 & 3.3 & 4.4 & 1.1 & 3.9 & 7.7 & 5.0 & 4.4 & 4.5 & 4.5 & 5.0 & 4.5 & 4.5 & 4.3 \\
\hline GDP deflator in US dollar terms (change in percent) & 14.3 & 10.4 & 9.9 & 8.2 & 10.3 & 18.2 & -0.6 & 15.5 & 11.0 & 9.2 & 3.3 & 9.4 & 1.1 & -0.1 & 0.1 \\
\hline Effective interest rate (percent) 5/ & 2.0 & 1.3 & 1.2 & 1.2 & 0.4 & 1.4 & 1.3 & 1.4 & 1.5 & 1.5 & 1.6 & 1.4 & 1.7 & 1.9 & 1.8 \\
\hline Growth of exports of G\&S (U.S. dollar terms, in percent) & 35.6 & 14.9 & -1.2 & 15.2 & 27.6 & 21.6 & -25.7 & 17.7 & 5.2 & 2.0 & 1.2 & 3.7 & -0.3 & 11.7 & 3.5 \\
\hline Growth of imports of G\&S (U.S. dollar terms, in percent) & 22.1 & 29.6 & 20.3 & 12.2 & 11.0 & -0.3 & -19.4 & 9.7 & 8.4 & 7.8 & 4.9 & 1.8 & 4.5 & 3.6 & 5.2 \\
\hline Grant element of new public sector borrowing (in percent) & & & & & & 35.7 & 35.7 & 35.7 & 35.7 & 35.7 & 35.7 & 35.7 & 35.7 & 35.7 & 35.7 \\
\hline Government revenues (excluding grants, in percent of GDP) & 34.5 & 38.2 & 32.8 & & & 37.0 & 24.2 & 24.2 & 25.5 & 24.5 & 24.1 & & 23.2 & 21.5 & 21.7 \\
\hline Aid flows (in billions of U.S. dollars) 7/ & 0.3 & 0.4 & 0.4 & & & 0.4 & 0.7 & 0.8 & 0.9 & 1.1 & 1.2 & & 2.2 & 2.6 & \\
\hline Of which: Grants & 0.1 & 0.1 & 0.1 & & & 0.1 & 0.2 & 0.1 & 0.2 & 0.3 & 0.3 & & 0.6 & 0.8 & \\
\hline Of which: Concessional loans & 0.3 & 0.3 & 0.4 & & & 0.3 & 0.5 & 0.7 & 0.7 & 0.8 & 0.9 & & 1.6 & 1.8 & \\
\hline Grant-equivalent financing (in percent of GDP) 8 / & $\ldots$ & $\ldots$ & $\ldots$ & & & 0.8 & 1.4 & 1.1 & 1.1 & 1.3 & 1.2 & & 1.8 & 1.6 & 2.0 \\
\hline Grant-equivalent financing (in percent of external financing) 8/ & $\ldots$ & $\ldots$ & $\ldots$ & & & 50.6 & 55.4 & 47.4 & 49.1 & 52.5 & 51.5 & & 53.1 & 56.3 & 50.6 \\
\hline \multicolumn{16}{|l|}{ Memorandum items: } \\
\hline Nominal GDP (in billions of US dollars) & 16.7 & 19.1 & 21.7 & & & 26.6 & 28.5 & 34.5 & 40.0 & 45.7 & 49.3 & & 65.3 & 93.9 & \\
\hline Nominal dollar GDP growth & 20.7 & 13.9 & 13.6 & & & 22.8 & 7.1 & 21.3 & 15.9 & 14.2 & 8.0 & 14.9 & 5.7 & 4.4 & 4.4 \\
\hline PV of PPG external debt (in billions of US dollars) & & & 3.6 & & & 3.7 & 3.9 & 4.2 & 4.6 & 5.0 & 5.5 & & 9.6 & 26.9 & \\
\hline (PVt-PVt-1)/GDPt-1 (in percent) & & & & & & 0.4 & 0.8 & 1.2 & 1.1 & 1.1 & 1.0 & 0.9 & 1.6 & 1.1 & 2.0 \\
\hline
\end{tabular}

1/ Includes both public and private sector external debt.

2)

/ Includes exceptional financing (i.e., changes in arrears and debt relief); changes in gross foreign assets; and valuation adjustments. For projections also includes contribution from price and exchange rate changes 5/ Current-year interest payments divided by previous period debt stock.

/ Historical averages and standard deviations are generally derived over the past 10 years, subject to data availability. 
Table 4. Republic of Yemen: Sensitivity Analysis for Key Indicators of Public and Publicly Guaranteed External Debt, 2008-28 (In percent)

\begin{tabular}{|c|c|c|c|c|c|c|c|c|}
\hline & \multicolumn{8}{|c|}{ Projections } \\
\hline & 2008 & 2009 & 2010 & 2011 & 2012 & 2013 & 2018 & 2028 \\
\hline \multicolumn{9}{|c|}{ PV of debt-to GDP ratio } \\
\hline Baseline & 14 & 14 & 12 & 11 & 11 & 11 & 15 & 29 \\
\hline \multicolumn{9}{|l|}{ A. Alternative Scenarios } \\
\hline A1. Key variables at their historical averages in $2008-28$ 1/ & 14 & 9 & 6 & 2 & $\ldots$ & .. & $\ldots$ & \\
\hline A2. New public sector loans on less favorable terms in $2008-28$ 2/ & 14 & 14 & 13 & 12 & 12 & 12 & 16 & 32 \\
\hline A3. Nonadjustment scenario & 14 & 15 & 14 & 13 & 13 & 22 & 64 & 223 \\
\hline \multicolumn{9}{|l|}{ B. Bound Tests } \\
\hline B1. Real GDP growth at historical average minus one standard deviation in 2009-10 & 14 & 14 & 13 & 12 & 12 & 12 & 16 & 30 \\
\hline B2. Export value growth at historical average minus one standard deviation in 2009-10 3/ & 14 & 11 & 12 & 11 & 11 & 11 & 14 & 28 \\
\hline B3. US dollar GDP deflator at historical average minus one standard deviation in 2009-10 & 14 & 14 & 15 & 14 & 13 & 13 & 18 & 34 \\
\hline B4. Net non-debt creating flows at historical average minus one standard deviation in 2009-10 4/ & 14 & 14 & 11 & 10 & 10 & 10 & 14 & 28 \\
\hline B5. Combination of B1-B4 using one-half standard deviation shocks & 14 & 5 & -1 & 0 & 0 & 1 & 6 & 27 \\
\hline B6. One-time 30 percent nominal depreciation relative to the baseline in $20095 /$ & 14 & 20 & 18 & 16 & 16 & 16 & 21 & 41 \\
\hline B7. Oil price $\$ 10$ below baseline projection in $2009-11$ & 14 & 15 & 13 & 12 & 11 & 11 & 15 & 29 \\
\hline \multicolumn{9}{|c|}{ PV of debt-to-exports ratio } \\
\hline Baseline & 39 & 55 & 51 & 53 & 57 & 61 & 109 & 189 \\
\hline \multicolumn{9}{|l|}{ A. Alternative Scenarios } \\
\hline A1. Key variables at their historical averages in $2008-28$ 1/ & 39 & 38 & 24 & 9 & $\ldots$ & $\ldots$ & $\ldots$ & \\
\hline A2. New public sector loans on less favorable terms in $2008-282 /$ & 39 & 56 & 52 & 55 & 59 & 65 & 118 & 215 \\
\hline A3. Nonadjustment scenario & 40 & 59 & 59 & 65 & 73 & 98 & 336 & 1486 \\
\hline \multicolumn{9}{|l|}{ B. Bound Tests } \\
\hline B1. Real GDP growth at historical average minus one standard deviation in 2009-10 & 39 & 55 & 51 & 53 & 57 & 61 & 109 & 189 \\
\hline B2. Export value growth at historical average minus one standard deviation in $2009-103 /$ & 39 & 37 & 56 & 58 & 62 & 67 & 121 & 215 \\
\hline B3. US dollar GDP deflator at historical average minus one standard deviation in 2009-10 & 39 & 55 & 51 & 53 & 57 & 61 & 109 & 189 \\
\hline B4. Net non-debt creating flows at historical average minus one standard deviation in 2009-10 4/ & 39 & 56 & 46 & 48 & 52 & 56 & 102 & 186 \\
\hline B5. Combination of B1-B4 using one-half standard deviation shocks & 39 & 16 & -3 & -1 & 2 & 4 & 35 & 132 \\
\hline B6. One-time 30 percent nominal depreciation relative to the baseline in $20095 /$ & 39 & 55 & 51 & 53 & 57 & 61 & 109 & 189 \\
\hline B7. Oil price $\$ 10$ below baseline projection in $2009-11$ & 39 & 64 & 58 & 59 & 58 & 63 & 111 & 191 \\
\hline \multicolumn{9}{|c|}{ PV of debt-to-revenue ratio } \\
\hline Baseline & 37 & 57 & 51 & 45 & 45 & 46 & 64 & 133 \\
\hline A. Alternative Scenarios & & & & & & & & \\
\hline A1. Key variables at their historical averages in 2008-28 1/ & 37 & 39 & 23 & 7 & $\ldots$ & $\ldots$ & $\ldots$ & $\ldots$ \\
\hline A2. New public sector loans on less favorable terms in $2008-28$ 2/ & 37 & 57 & 52 & 47 & 47 & 49 & 69 & 151 \\
\hline A3. Nonadjustment scenario & 38 & 62 & 60 & 62 & 65 & 92 & 270 & 1190 \\
\hline B. Bound Tests & & & & & & & & \\
\hline B1. Real GDP growth at historical average minus one standard deviation in 2009-10 & 37 & 59 & 54 & 48 & 48 & 49 & 68 & 141 \\
\hline B2. Export value growth at historical average minus one standard deviation in 2009-10 3/ & 37 & 45 & 48 & 43 & 43 & 44 & 62 & 132 \\
\hline B3. US dollar GDP deflator at historical average minus one standard deviation in 2009-10 & 37 & 57 & 61 & 54 & 54 & 55 & 76 & 159 \\
\hline B4. Net non-debt creating flows at historical average minus one standard deviation in 2009-10 4/ & 37 & 57 & 46 & 41 & 41 & 42 & 60 & 131 \\
\hline B5. Combination of B1-B4 using one-half standard deviation shocks & 37 & 23 & -4 & -1 & 2 & 4 & 27 & 124 \\
\hline B6. One-time 30 percent nominal depreciation relative to the baseline in $20095 /$ & 37 & 81 & 72 & 64 & 64 & 66 & 91 & 190 \\
\hline B7. Oil price $\$ 10$ below baseline projection in $2009-11$ & 37 & 66 & 58 & 51 & 46 & 48 & 65 & 135 \\
\hline Debt service-to-export & atio & & & & & & & \\
\hline Baseline & 3 & 4 & 3 & 4 & 4 & 4 & 5 & 10 \\
\hline A. Alternative Scenarios & & & & & & & & \\
\hline A1. Key variables at their historical averages in $2008-28$ 1/ & 3 & 4 & 3 & 3 & 2 & 2 & $\ldots$ & $\cdots$ \\
\hline A2. New public sector loans on less favorable terms in $2008-28$ 2/ & 3 & 4 & 4 & 4 & 4 & 4 & 7 & 12 \\
\hline A3. Nonadjustment scenario & 3 & 4 & 4 & 4 & 4 & 5 & 16 & 90 \\
\hline B. Bound Tests & & & & & & & & \\
\hline B1. Real GDP growth at historical average minus one standard deviation in 2009-10 & 3 & 4 & 3 & 4 & 4 & 4 & 5 & 10 \\
\hline B2. Export value growth at historical average minus one standard deviation in 2009-10 3/ & 3 & 3 & 4 & 4 & 4 & 4 & 5 & 11 \\
\hline B3. US dollar GDP deflator at historical average minus one standard deviation in 2009-10 & 3 & 4 & 3 & 4 & 4 & 4 & 5 & 10 \\
\hline B4. Net non-debt creating flows at historical average minus one standard deviation in 2009-10 4/ & 3 & 4 & 3 & 3 & 3 & 4 & 5 & 10 \\
\hline B5. Combination of B1-B4 using one-half standard deviation shocks & 3 & 3 & 2 & 2 & 2 & 2 & 1 & 5 \\
\hline B6. One-time 30 percent nominal depreciation relative to the baseline in $20095 /$ & 3 & 4 & 3 & 4 & 4 & 4 & 5 & 10 \\
\hline B7. Oil price $\$ 10$ below baseline projection in $2009-11$ & 3 & 4 & 4 & 4 & 4 & 4 & 5 & 10 \\
\hline Debt service-to-revenu & ratio & & & & & & & \\
\hline Baseline & 3 & 4 & 3 & 3 & 3 & 3 & 3 & 7 \\
\hline A. Alternative Scenarios & & & & & & & & \\
\hline A1. Key variables at their historical averages in $2008-281 /$ & 3 & 4 & 3 & 2 & 2 & 1 & $\ldots$ & \\
\hline A2. New public sector loans on less favorable terms in $2008-28$ 2/ & 3 & 4 & 3 & 3 & 3 & 3 & 4 & 8 \\
\hline $\begin{array}{l}\text { A3. Nonadjustment scenario } \\
\text { B. Bound Tests }\end{array}$ & 3 & 4 & 4 & 4 & 4 & 5 & 13 & 72 \\
\hline B1. Real GDP growth at historical average minus one standard deviation in 2009-10 & 3 & 4 & 4 & 3 & 3 & 3 & 3 & 7 \\
\hline B2. Export value growth at historical average minus one standard deviation in 2009-10 3/ & 3 & 4 & 3 & 3 & 3 & 3 & 2 & 7 \\
\hline B3. US dollar GDP deflator at historical average minus one standard deviation in $2009-10$ & 3 & 4 & 4 & 4 & 3 & 3 & 3 & 8 \\
\hline B4. Net non-debt creating flows at historical average minus one standard deviation in 2009-10 4/ & 3 & 4 & 3 & 3 & 3 & 3 & 3 & 7 \\
\hline B5. Combination of B1-B4 using one-half standard deviation shocks & 3 & 4 & 3 & 2 & 2 & 2 & 1 & 5 \\
\hline B6. One-time 30 percent nominal depreciation relative to the baseline in $20095 /$ & 3 & 6 & 5 & 4 & 4 & 4 & 4 & 10 \\
\hline B7. Oil price $\$ 10$ below baseline projection in $2009-11$ & 3 & 4 & 4 & 3 & 3 & 3 & 3 & 7 \\
\hline Memorandum item: & & & & & & & & \\
\hline Grant element assumed on residual financing (i.e., financing required above baseline) 6/ & 36 & 36 & 36 & 36 & 36 & 36 & 36 & 36 \\
\hline
\end{tabular}

Source: Staff projections and simulations.

1/ Variables include real GDP growth, growth of GDP deflator (in U.S. dollar terms), non-interest current account in percent of GDP, and non-debt creating flows. 2/ Assumes that the interest rate on new borrowing is by 2 percentage points higher than in the baseline; grace and maturity periods are the same as in the baseline. 3/ Exports values are assumed to remain permanently at the lower level, but the current account as a share of GDP is assumed to return to its baseline level after the shock (implicitly assuming an offsetting adjustment in import levels).

4/ Includes official and private transfers and FDI.

$5 /$ Depreciation is defined as percentage decline in dollar/local currency rate, such that it never exceeds 100 percent.

6/ Applies to all stress scenarios except for A2 (less favorable financing) in which the terms on all new financing are as specified in footnote 2. 
Figure 1. Republic of Yemen: Indicators of Public and Publicly Guaranteed External Debt Under Alternatives Scenarios, 2008-28 1/
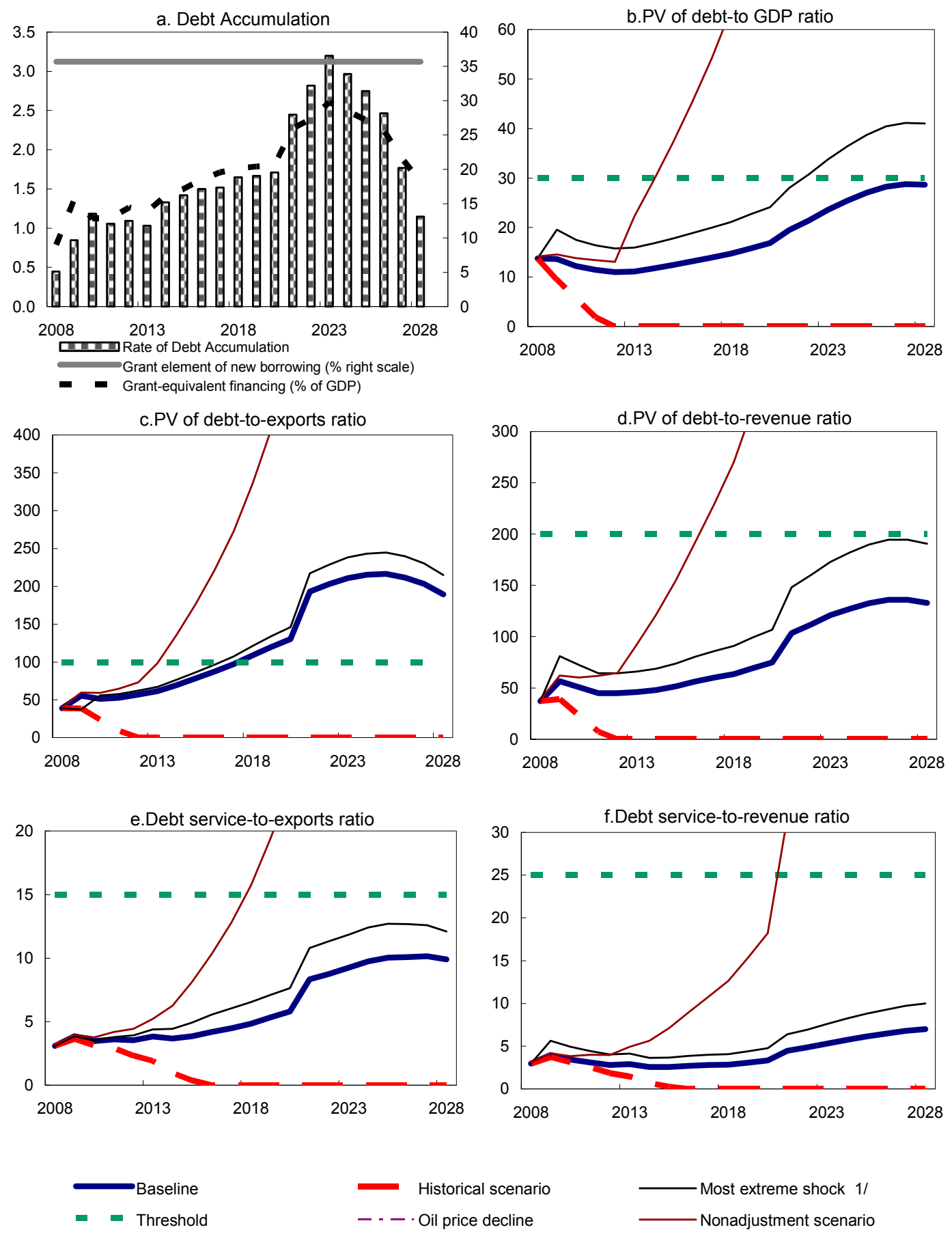

Source: Staff projections and simulations.

$1 /$ The most extreme stress test is the test that yields the highest ratio in 2018. In figure b. it corresponds to a one-time depreciation shock; in c. to a export shock; in d. to a one-time depreciation shock; in e. to a terms shock and in f. to a one-time depreciation shock 
Figure 2. Republic of Yemen: Indicators of Public Debt Under Alternative Scenarios, 2008-28 1/
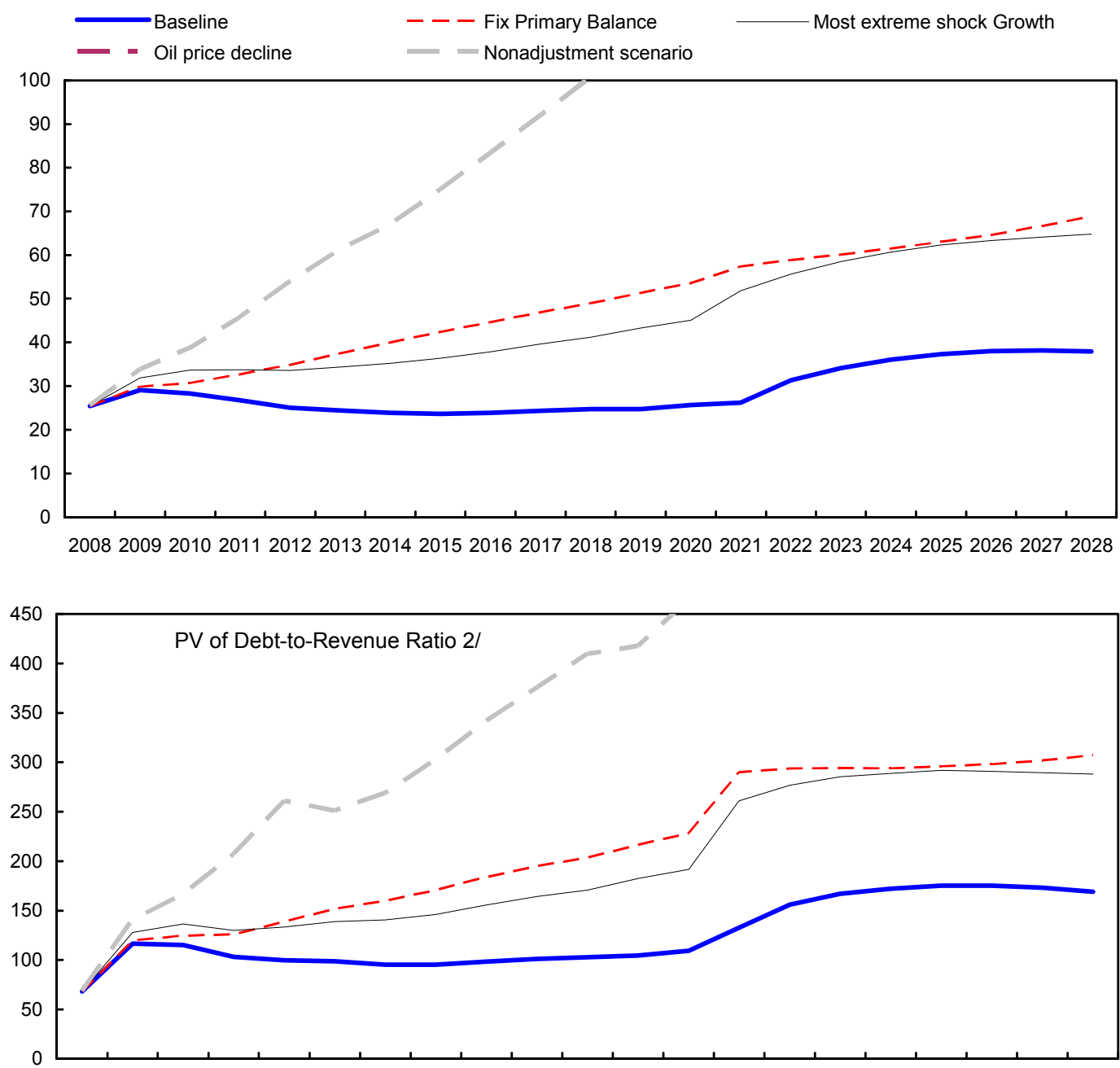

200820092010201120122013201420152016201720182019202020212022202320242025202620272028

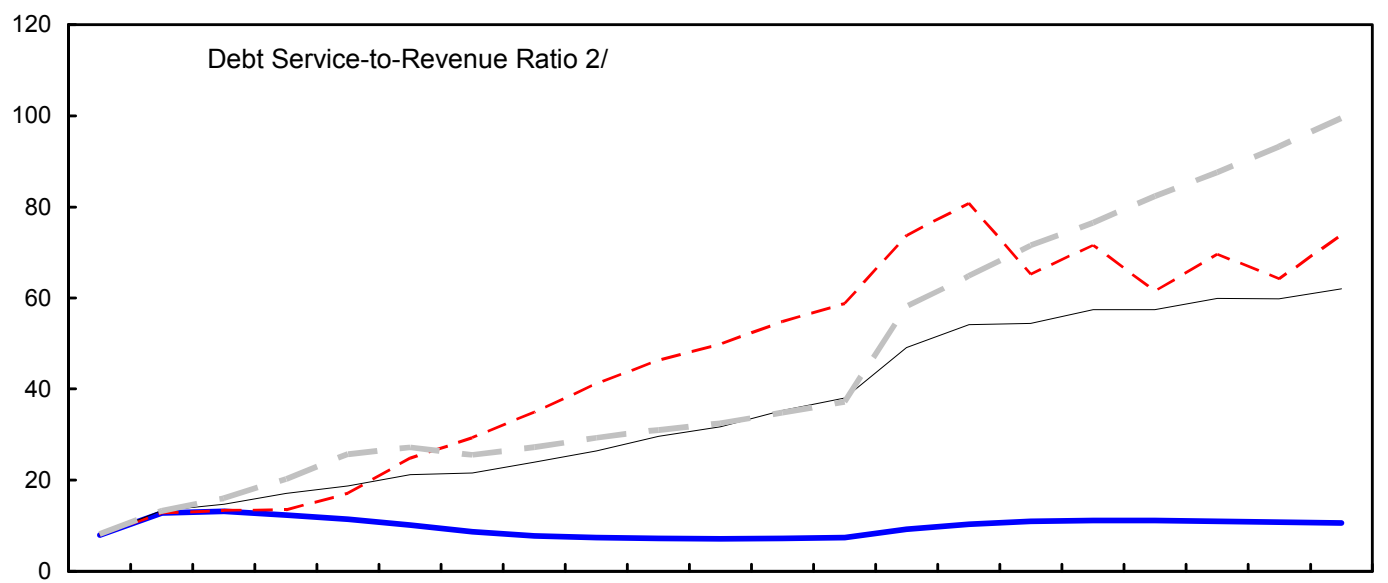

200820092010201120122013201420152016201720182019202020212022202320242025202620272028

Sources: Yemeni authorities; and Fund staff estimates and projections.

$1 /$ The most extreme stress test is the test that yields the highest ratio in 2018.

2/ Revenues are defined inclusive of grants. 


\title{
INTERNATIONAL MONETARY FUND
}

\section{REPUBLIC OF YEMEN}

\section{Staff Report for the 2008 Article IV Consultation-Informational Annex}

\author{
Prepared by the Middle East and Central Asia Department
}

(In consultation with other departments)

January 21, 2009

Contents

Annexes

I. Fund Relations .2

II. World Bank Relations........................................................................................ 6

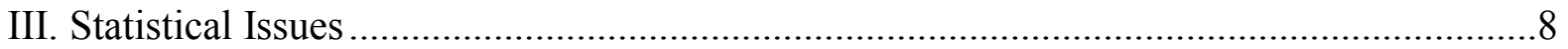




\section{Annex I. Republic of Yemen: Fund Relations}

(As of October 31, 2008)

I. Membership Status: Joined May 22,1990 and has Article VIII status.

II. General Resources Account:

Quota

Fund holdings of currency

Reserve position

Holdings exchange rate

III. SDR Department:

Net cumulative allocation

Holdings

IV. Outstanding Purchases and Loans:

Extended arrangements

PRGF arrangements
SDR Million

243.50

246.24

0.01

SDR Million

28.74

1.56

SDR Million

2.75

60.05
Percent of Quota

100.00

101.12

0.01

V. Latest Financial Arrangements:

\begin{tabular}{lcccc}
\hline Type & $\begin{array}{c}\text { Approval } \\
\text { Date }\end{array}$ & $\begin{array}{c}\text { Expiration } \\
\text { Date }\end{array}$ & $\begin{array}{c}\text { Amount Approved } \\
\text { (SDR Million) }\end{array}$ & $\begin{array}{c}\text { Amount Drawn } \\
\text { (SDR Million) }\end{array}$ \\
\hline EFF & $10 / 29 / 1997$ & $10 / 28 / 2001$ & 72.90 & 46.50 \\
PRGF & $10 / 29 / 1997$ & $10 / 28 / 2001$ & 264.75 & 238.75 \\
Stand-By & $3 / 20 / 1996$ & $6 / 19 / 1997$ & 132.38 & 132.38
\end{tabular}

VI. Projected Payments to Fund: ${ }^{12}$

\begin{tabular}{lrrrrr}
\hline & \multicolumn{5}{c}{ Forthcoming } \\
\cline { 2 - 6 } & 2008 & 2009 & 2010 & 2011 & 2012 \\
\hline Principal & 0.92 & 28.38 & 17.75 & 15.75 & 0.00 \\
Charges/Interest & 0.37 & 0.78 & 0.65 & 0.56 & 0.52 \\
\hline Total & 1.28 & 29.16 & 18.40 & 16.31 & 0.52 \\
\hline
\end{tabular}

\footnotetext{
${ }^{1}$ When a member has overdue financial obligations outstanding for more than three months, the amount of such arrears will be shown in this section.

${ }^{2}$ This schedule presents all currently scheduled payments to the IMF, including repayment expectations and repayment obligations. The IMF Executive Board can extend repayment expectations (within predetermined limits) upon request by the debtor country if its external payments position is not strong enough to meet the expectations without undue hardship or risk.
} 


\section{Safeguards Assessment}

Under the Fund's safeguards assessment policy, the Central Bank of Yemen (CBY) was subject to the transitional procedures with respect to the EFF arrangement which expired on October 28, 2001. The assessment, which was completed on May 23, 2001, concluded that the CBY's external audit mechanism was not fully adequate at the time.

\section{Exchange Arrangements}

The currency of Yemen is the Yemeni rial. The Yemeni authorities maintain that the current exchange rate system is a free float. However, staff are of the view that the exchange rate system is a facto crawling peg, in which the rate of crawl has recently slowed to resemble a conventional peg. Accordingly, under the IMF's classification, Yemen is currently considered a de facto conventional peg.

Yemen has accepted the obligations of Article VIII, Sections 2, 3, and 4, of the Articles of Agreement and maintains an exchange system that is free of multiple currency practices and restrictions on the making of payments and transfers for current international transactions. The authorities most recent notification under Decision 144 advised that, in accordance with UN Security Council Resolutions, Yemen had taken measures to block the accounts of certain individuals and organizations.

\section{Article IV Consultation}

The latest Article IV consultation was concluded on September 17, 2007. Yemen is on the standard 12-month consultation cycle.

\section{FSAP Participation}

FSAP (with the World Bank), October-November 2000.

\section{Technical Assistance}

\section{A. IMF}

FAD—Pension Reform, August 2001

FAD-Reform of the Budgetary Process, April 2002

FAD—Public Expenditure Management Expert Installation, September 2002

FAD-Tax Policy, Tax Administration and Customs Reform, October-November 2002

FAD-Public Expenditure Management Advisor, August 2003-January 2004

FAD—Public Expenditure Management, March-April 2004

FAD—Support to LTO, April 2005

FAD-GST Implementation, April 2005

FAD-Support to LTO and GST Implementation, November 2005

FAD—Reforming Tax Administration and Implementing GST, June 2006 
FAD_-Treasury Function and Related PFM Reforms, July 2007

FAD_-Introducing a Treasury System, October 2007

LEG-AML/CFT Diagnostic, May 2006

LEG-AML/CFT Legal Drafting, November 2006

MAE_-Foreign reserves management, February-March 2001

MAE - Technical Assistance and Training Coordination and Expenditure Resource Mobilization, March 2005

MAE-ST Regional Expert Assignment, June-July 2005

MAE — ST Regional Expert Assignment, August 2005

MAE - Support for the regulatory framework of the Central Bank of Yemen, September-October 2005

MFD_Liquidity Management, March-April 2005

MFD_Regional Advisor, September 2005

MFD_-Payment Systems and Monetary Operations, October 2005

MFD - Support for the Central Bank of Yemen Credit Registry, November-December 2005

MCM-METAC - Technical Assistance on Banking Supervision, May 2006

MCM-Banking Supervision, June-July 2006

MCM-Credit Registry, July 2006

MCM-METAC - Banking Supervision, December 2006

MCM-METAC - Needs Assessment Visit, March-April 2007

MCM-Payment Systems, Jan-Feb 2008

OTM-TCAP Review, March 2004

OTM-Yemen - TCAP, March-April 2004

OTM-METAC - Needs Assessment Mission, February 2005

OTM-METAC - Price Statistics Mission, October 2008

STA - Balance of Payments Statistics, January 2003

STA - Government Finance Statistics, January 2004

STA-National Accounts Statistics, January 2004

STA - National Accounts Statistics, May-June 2004

STA - Balance of Payments Statistics, September 2005

STA-Multisector Statistics Mission, August-September 2007 ) 


\section{B. UNDP/IMF/DFID Program}

MAE_LTE on Bank Supervision, May 1997-May 2001

MED_LTE on Debt Management, July 1997-March 2001

STA - LTE on Balance of Payments Statistics, February 1998-February 2000

FAD - LTE on Budget Management, March 1998-June 2001, and September 2002-January 2004

FAD_-Peripatetic Experts on Customs Reform, July 1999-July 2001

STA-Peripatetic Expert on National Accounts, September 2001-August 2002

MAE_-Peripatetic Expert on Foreign Reserves Management since April 2002

C. IMF/World Bank Program

MAE-FSAP, October-November 2000

FAD_AFMIS Inspection Mission, September-October 2004

XII. Resident Representatives: None 


\section{Annex II. Republic of Yemen: World Bank Relations}

\section{A. Partnership in Yemen's Development Strategy}

1. Relations between the World Bank and the Government of Yemen are close and continue to cover knowledge and lending services in sectors critical to development and poverty reduction. The Bank's Board of Directors discussed the 2006-09 Country Assistance Strategy (CAS) for Yemen in June 2006. This CAS was prepared after extensive consultations with central and local government officials, civil society, private sector and other donors. It also benefited from the Government's Progress Report for the first two years of implementation of the First Poverty Reduction Strategy Paper (2003-05) as well as the 2006 Country Assistance Evaluation prepared by the Independent Evaluation Group of the World Bank.

2. The current CAS is based on four pillars: (a) increasing non-oil growth; (b) improving human development outcomes; (c) improving fiscal sustainability; and (d) addressing the resource sustainability crisis. During the CAS period, IDA intends to provide about \$100 million annually in financial assistance to Yemen through a selective program of lending operations complemented by a strategic program of analytical and learning services. Given the relatively limited amount of IDA resources available to Yemen, the Bank's larger contribution comes from its catalytic role in leveraging donors' resources, providing technical assistance to the Government and working with other donors to mainstream new implementation approaches that can enhance sectoral performance.

3. A new CAS is under preparation (Board scheduled in Q4 FY09), in parallel to the Government's mid-term review of its 2006-10 Development Plan for Poverty Reduction.

4. In mid-November 2006, the World Bank co-chaired with the Yemen's Government a Consultative Group (CG) meeting hosted by the UK Department of International Development, and sponsored by the Gulf Cooperation. The CG was attended by senior officials from 39 countries and international development agencies, and a total amount of US $\$ 4.7$ billion were pledged to finance Yemen's development for the four year period 2007-10. The pledge represented over 85 percent of the Government's estimated external financing needs.

5. As part of the CAS, the International Finance Corporation (IFC), the private sector arm of the World Bank Group, is supporting the development of the private sector in Yemen through investments and technical assistance activities. The IFC focuses on enhancing competitiveness of the private sector, further deepening the financial sector, promoting investments in areas newly opened for private sector participation, encouraging sustainable social and environmental development, and promoting good corporate governance. 


\section{B. Status of the World Bank Portfolio}

6. IDA. As of end of December12, 2008, IDA had approved 139 projects for Yemen, valued at about US $\$ 2.6$ billion, of which about US $\$ 2.2$ billion have been disbursed. The current portfolio has 19 active projects with a total net commitment of about US\$881 million, of which US\$431 million are undisbursed. The sectoral composition (by value) of the current portfolio is as follows: 47 percent for infrastructure projects (of which 22 percent for water), 19 percent for agriculture, 12 percent for education, 12 percent for health/social protection, 6 percent for a budget support, and 5 percent for public sector governance. Over the last three years, portfolio performance has remained stable - disbursement ratio stands at 23 percent in FY08. All the 19 projects in the portfolio are currently rated satisfactory. IDA financial support will be provided as grants under IDA15.

7. IFC. In response to the Government of Yemen's efforts in opening certain industries to private participation, IFC established an office in Sana'a in 2005 and has increased investment operations in the country since then. IFC's commitments have risen steadily in Yemen, from no investments in FY05 to US\$91 million in FY07 and US\$24 million in three projects in FY08. IFC is active in the financial sector, SME development, business enabling environment, and preparation of a legal framework for mining. IFC has also increased its activity in FY08 in Public Private Partnership/Transaction Advisory.

8. In FY08, IFC committed US\$24 million comprising: (i) US\$5.8 million trade finance guarantees with Saba Islamic Bank; (ii) US\$8 million in University of Science and Technology; and (iii) US\$10 million in Maghrabi hospital. On the advisory front, business management training (Business Edge) for almost 20,000 entrepreneurs and other individuals (including 13 percent women) has been completed since FY05 in partnership with five local training providers. In FY08, approximately 3,000 entrepreneurs and other individuals were trained. In addition, IFC signed agreements with two large fast moving consumer goods companies to train their SME wholesalers. IFC's leasing TA is also commissioning a study to assess and quantify the Yemeni leasing market to provide market information to encourage investment. In FY09 to date, IFC has committed $\$ 0.39$ million in trade finance guarantees with Saba Islamic Bank.

9. Relation with the Multilateral Investment Guarantee Agency (MIGA): Currently, MIGA does not have any activities in Yemen. However, the ministry of planning and international cooperation has recently requested assistance to review its institutional framework for investment promotion. In response, FIAS/MIGA is planning a rapid diagnostic assessment of the overall investment promotion institutional arrangements in Yemen with a view to offering recommendations for the rationalization of roles, mandates and functions in this important strategic area of activity. 


\section{Annex III. Republic of Yemen: Statistical Issues}

1. Data provision has some shortcomings, but is broadly adequate for surveillance. The most affected areas are: national accounts, price statistics, government financing statistics (GFS), and balance of payments statistics. The Republic of Yemen has participated in the General Data Dissemination System (GDDS) since April 2001. While some progress has been made, considerable scope remains to improve the collection and dissemination of economic statistics, in line with Yemen's commitments under the GDDS. GDDS metadata for most data categories have not been updated since May 2004.

\section{Real sector statistics}

2. The Central Statistics Organization (CSO) recently revised and rebased the national accounts with the help of an expert from the United Nations Economic and Social Commission for Western Asia (ESCWA). Although important progress has been achieved in terms of coverage, classification, and compilation methods in accordance with the System of National Accounts 1993 (1993 SNA), significant work remains to be done to improve quality of the data and the compilation methods.

3. Based on the recommendations of the technical assistance provided by STA and METAC during September 2001 to November 2006, additional measures and work are needed: to ensure the accuracy and the speed of collecting and processing survey results; to compile timely supply and use tables, to conduct quarterly establishment sample surveys that will provide short-term indicators for moving annual benchmark series; to use the results of 2005 Household Budget Survey (HBS) that will improve estimates of household final consumption; to conduct new surveys in areas uncovered; to better identify the informal sector; and to update survey samples that will improve coverage. There is also a need to develop short-term indicators for both current and constant prices, and to apply the $1993 \mathrm{SNA}$ framework consistently for all published national accounts data.

4. Regarding price statistics, some improvements have been made in the compilation of the CPI and the production of foreign trade price indices. METAC assisted the CSO in developing a PPI, however its development stopped when financing was exhausted. With the assistance of STA, the CSO constructed a CPI that is consistent with international standards, updated the weights using the 1998 HBS, broadened geographic coverage with a sufficient number of consumption items, and introduced a new framework to ensure consistency in data collection (in timing, good specifications, and location). Recently, the CSO, with the help of an expert from METAC, has rebased CPI series to 2005 and recalculated the index for 2005-2008. The CSO is also currently working on updating the weights of the CPI basket to reflect the results of the $2005 \mathrm{HBS}$, and is considering reducing the number of commodities in the basket from the current coverage of 900 goods. STA missions have recommended further improving the sources of data in general, expanding the price statistics to cover different areas, and enhancing training and internal coordination within the CSO. 


\section{Government finance statistics}

5. The reliability and timeliness of GFS remain weak - particularly for detailed revenue, expenditure and financing items. Yemen has received substantial technical assistance from international agencies to improve source data from the accounting and budgeting frameworks and information systems and to improve compilation methods, but progress has been limited. There appear to be intersectoral discrepancies between the available fiscal data and the Central Bank of Yemen's (CBY) monetary statistics and balance of payments data.

6. The January 2004 GFS mission found that, while the institutional coverage and available detail of data have improved, there were still numerous departures from international standards in classification and coverage. The mission encouraged the authorities to: include additional information on financing and debt in the GFS Bulletin; expand their data dissemination by communicating the GFS Bulletin, or the relevant data, to STA for re-dissemination; and renew the dialogue and remote technical assistance for developing their GFS. The August-September 2007 multisector statistics mission found that many of the

previously identified weaknesses remained in data compilation and dissemination-including the incomplete coverage of the social security funds and the lack of coverage of certain transactions. These shortcomings contribute, in turn, to problems in the compilation of monetary and national accounts statistics. The concepts and definitions used to compile GFS are in transition from GFS 1986 to GFSM 2001, and the authorities' GFS Bulletin reports fiscal data using a mixture of both.

7. Fiscal data are published in the quarterly Bulletin of Government Finance Statistics (GFS Bulletin) on the MoF website (www.mof.gov.ye), which provides annual, quarterly, and monthly data, albeit with significant lags and irregularity. The authorities have not reported data for publication in the Government Finance Statistics Yearbook from 2000 onwards. No sub-annual data are published in the International Financial Statistics.

\section{Monetary and financial statistics}

8. The most reliable and timely data are the monetary and financial statistics produced by the CBY. The CBY disseminates data on total official reserve assets and monetary statistics with a lag of up to two months. To strengthen monetary statistics further, the August-September 2007 multisector mission recommended to: (a) treat repurchase agreements as collateralized loans; (b) separately identify CBY's and other banks' positions with the local governments (as a component of general government); (c) uniformly distinguish between private and public nonfinancial enterprises based on the effective control principle; (d) consult with the Ministry of Finance (MoF) on a consistent institutional coverage of the government sector; (e) consult with the IMF's Finance Department on the appropriate accounting for the IMF accounts in the CBY's balance sheet; and (f) in due course, uniformly adopt market price or equivalent valuation for securities and shares. The CBY has made some improvements in the formatting and classification of items in the monetary survey based on the recommendations of the multisector mission, but does not yet 
report monetary data to the IMF's Statistics Department (STA) using Standardized Report Forms.

\section{External sector statistics}

9. The CBY is responsible for compiling and disseminating balance of payments statistics, and more recently, the international investment position (IIP) statistics based on the IMF's Balance of Payments Manual, Fifth Edition. Compilation tasks are performed on an ad hoc basis, mostly relying on surveys (response rates that are generally poor). Successive STA balance of payments statistics missions (2002, 2003, and 2005) have sought to facilitate implementation of the action plan recommended by the IMF's resident advisor on balance of payments statistics (1998-2000), with only limited success.

10. The 2007 multisector mission underlined weak coordination between the CBY and other government agencies (such as the Customs Authority, the CSO, and the Ministry of Oil and Mining Resources) as among the main factors impeding progress in statistical reform. Coverage of the oil and gas industry transactions remains weak, and there are gaps in the coverage of some current account items such as merchandise trade, transportation, travel, and remittances; and in the financial account—notably in foreign direct investment (FDI).

11. The 2007 multisector mission reaffirmed earlier STA missions' call for better coordination between the CBY and other government agencies for timely and effective data collection and compilation (particularly in the area of merchandise trade statistics), and for the reinstitution of discontinued surveys. Data questionnaires on FDI and selected items in services have either been discontinued or not followed up, but the authorities are working to reestablish FDI surveys. There is scope for further training in survey techniques and in IIP compilation, and the authorities should improve the documentation and dissemination of information on sources and methods.

12. Quarterly balance of payments until 2007 and IIP data until end-2006 are provided with long lags for publication in the Fund's IFS and Balance of Payments Statistics Yearbook (BOPSY). The CBY publishes external debt statistics within one quarter after the end of the reference quarter for the banking sector, general government, and monetary authority. 


\section{Republic of Yemen: Table of Common Indicators Required for Surveillance (As of December 3, 2008)}

\begin{tabular}{|c|c|c|c|c|c|}
\hline & $\begin{array}{c}\text { Date of } \\
\text { Latest } \\
\text { Observation }\end{array}$ & $\begin{array}{l}\text { Date } \\
\text { Received }\end{array}$ & $\begin{array}{c}\text { Frequency } \\
\text { of } \\
\text { Data }^{7}\end{array}$ & $\begin{array}{l}\text { Frequency } \\
\quad \text { of } \\
\text { Reporting }^{7}\end{array}$ & $\begin{array}{l}\text { Frequency } \\
\text { of } \\
\text { Publication }^{7}\end{array}$ \\
\hline Exchange rates & Oct. 2008 & Nov 19, 2008 & $\mathrm{D}$ & $\mathrm{D}$ & $\mathrm{D}$ \\
\hline $\begin{array}{l}\text { International reserve assets and reserve } \\
\text { liabilities of the monetary authorities }{ }^{1}\end{array}$ & Sept. 2008 & Nov 1, 2008 & M & M & A \\
\hline Reserve/base money & Sept. 2008 & Nov 1, 2008 & M & M & M \\
\hline Broad money & Sept. 2008 & Nov 1, 2008 & M & M & M \\
\hline Central bank balance sheet & Sept. 2008 & Nov 1, 2008 & M & M & M \\
\hline $\begin{array}{l}\text { Consolidated balance sheet of the } \\
\text { banking system }\end{array}$ & Sept. 2008 & Nov 1, 2008 & M & M & M \\
\hline Interest rates $^{2}$ & Oct. 2008 & Nov 20, 2008 & M & M & M \\
\hline Consumer price index & Jul 30, 2008 & Oct 24, 2008 & M & M & $M$ \\
\hline $\begin{array}{l}\text { Revenue, expenditure, balance and } \\
\text { composition of financing }{ }^{3} \text {-general } \\
\text { government }\end{array}$ & Jun 30, 2008 & Oct 27, 2008 & M & I & Q \\
\hline $\begin{array}{l}\text { Revenue, expenditure, balance and } \\
\text { composition of financing }{ }^{3} \text {-central } \\
\text { government }\end{array}$ & Jun 30, 2008 & Oct 27, 2008 & M & 1 & Q \\
\hline $\begin{array}{l}\text { Stocks of central government and central } \\
\text { government-guaranteed debt }{ }^{5}\end{array}$ & Jul 31, 2008 & Sept 15, 2008 & M & M & M \\
\hline External current account balance & Q4 2007 & Sept 23, 2008 & Q & A & A \\
\hline $\begin{array}{l}\text { Exports and imports of goods and } \\
\text { services }\end{array}$ & Q4 2007 & Sept 23, 2008 & Q & $A$ & A \\
\hline GDP/GNP & 2007 & Oct 24, 2008 & $A$ & $A$ & $A$ \\
\hline Gross external debt & Sept 30, 2008 & Nov. 2008 & Q & Q & $Q$ \\
\hline International Investment Position ${ }^{6}$ & Q4 2006 & Oct 18, 2007 & Q & A & A \\
\hline
\end{tabular}

${ }^{1}$ Includes reserve assets pledged or otherwise encumbered as well as net derivative positions.

${ }^{2}$ Both market-based and officially-determined, including discount rates, money market rates, rates on treasury bills, notes and bonds.

${ }^{3}$ Foreign, domestic bank, and domestic nonbank financing.

${ }^{4}$ The general government consists of the central government (budgetary funds, extra budgetary funds, and social security funds) and state and local governments.

${ }^{5}$ Including currency and maturity composition.

${ }^{6}$ Includes external gross financial asset and liability positions vis-à-vis nonresidents.

${ }^{7}$ Daily (D), Weekly (W), Monthly (M), Quarterly (Q), Annually (A), Irregular (I); Not Available (NA). 


\section{Statement by the IMF Staff Representative on the Republic of Yemen February 23, 2009}

1. This statement summarizes information on recent developments in Yemen that has become available since the staff report was issued to the Board on January 22, 2009. This information does not change the thrust of the staff appraisal.

2. The WEO oil price baseline was revised in January. The average international oil price is now projected at $\$ 50$ per barrel in 2009, compared with the previous assumption of $\$ 54.25$ per barrel. As a result, under the adjustment scenario outlined in the staff report, the 2009 fiscal deficit is now projected at 6.1 percent of GDP (up from 5.7 percent of GDP) and the current account deficit at 2.8 percent of GDP (up from 2.4 percent).

3. In December, the cabinet approved an adjustment to the 2009 budget based on reductions in nonpriority current expenditures, a postponement of selected investment projects, and intensified efforts at non-oil revenue mobilization. The adjustment aims at containing the deficit if oil prices remain below the initial budget assumption of $\$ 55$ per barrel. The authorities estimate that this adjustment would reduce public expenditure by about 1.3 percent of GDP. However, this adjustment does not incorporate the full range of measures envisaged in the adjustment scenario outlined in the staff report, and further fiscal efforts would be needed to contain the deficit in line with this scenario.

4. Coverage of the General Sales Tax (GST) has not yet been widened, although work continues on simplifying GST administration and identifying and registering new taxpayers. Work also continues on the income tax simplification project, with the assistance of the World Bank's Foreign Investment Advisory Service (FIAS).

5. The authorities have adopted a revised CPI series with technical assistance from the Fund. Under the new series, overall inflation was 11.2 percent in December 2007, rising to a peak of 24.7 percent in March 2008, and then declining to 10.8 percent in December 2008. The decline since March has been driven mostly by lower food prices. Monetary aggregates continued to slow in December, with reserve money, broad money, and private sector credit growth ending the year at 8.3 percent, 14.2 percent, and 17.5 percent, respectively. The central bank's own gross reserves have remained stable, ending 2008 at approximately $\$ 7.3$ billion, compared with the staff projection of $\$ 7$ billion-suggesting less pressure on the balance of payments than earlier anticipated. In January, the central bank reduced the floor on deposit-interest rates for the first time since 2000 from 13 to 12 percent. 


\section{INTERNATIONAL MONETARY FUND}

EXTERNAL

Public Information Notice

RELATIONS

DEPARTMENT

Public Information Notice (PIN) No. 09/29

FOR IMMEDIATE RELEASE

March 4, 2009
International Monetary Fund

$70019^{\text {th }}$ Street, NW

Washington, D. C. 20431 USA

\section{IMF Executive Board Concludes 2008 Article IV Consultation with the Republic of Yemen}

On January 16, 2008, the Executive Board of the International Monetary Fund (IMF) concluded the Article IV consultation with the Republic of Yemen. ${ }^{1}$

\section{Background}

Yemen remains one of the poorest countries in the region and is far from achieving the Millennium Development Goals. Oil production has been in decline since 2000. In the absence of major discoveries, reserves could be depleted in 10-12 years. The start of a new liquefied natural gas (LNG) project from 2009 will only partly compensate for the expected decline in crude oil. Yemen faces considerable challenges in dealing with the transition to a non-oil economy, generating strong non-hydrocarbon economic growth, ensuring fiscal and external sustainability, and reducing poverty and unemployment.

Recent economic performance in Yemen has been mixed. Overall real GDP grew by about 3.3 percent in 2007, reflecting real non-oil growth of 5.3 percent and a 13.1 percent decline in oil output. Overall growth is expected to pick up somewhat in 2008 , with non-oil growth around 4.8 percent and a smaller decline in oil output. Inflation has been a serious concern. After falling to about 9 percent at the end of 2007, core inflation (excluding the volatile prices of the narcotic qat) surged to 26 percent by March 2008, largely reflecting a similar increase in world commodity prices and local drought conditions.

\footnotetext{
${ }^{1}$ Under Article IV of the IMF's Articles of Agreement, the IMF holds bilateral discussions with members, usually every year. A staff team visits the country, collects economic and financial information, and discusses with officials the country's economic developments and policies. On return to headquarters, the staff prepares a report, which forms the basis for discussion by the Executive Board. At the conclusion of the discussion, the Managing Director, as Chairman of the Board, summarizes the views of Executive Directors, and this summary is transmitted to the country's authorities.
} 
A sizeable fiscal deficit emerged in 2007. A sharp decline in oil production, coupled with inflexible government expenditure and only marginal improvement in the tax-to-GDP ratio led to an overall fiscal deficit of 5.8 percent in 2007. For 2008, a deficit of around 5-6 percent of GDP is possible in the wake of the recent drop in international oil prices, continued rigid expenditures, and limited non-oil revenue improvements. As in previous years, a large supplementary budget was approved toward the end of the year to validate additional spending on fuel subsidies and an increase in wages, pensions, and social welfare transfers. Fuel subsidies continued to absorb a large part of the budget (about 14 percent of GDP), and together with the public sector wage bill account for about 50 percent of government expenditure.

Monetary policy in 2008 focused on exchange rate stability and controlling excess liquidity in the domestic banking system. The rial has remained steady against the US dollar since mid-2007, helping to mitigate imported inflation. In real effective terms, the rial appreciated by 8.5 percent in the twelve months to October. The Central Bank of Yemen (CBY) used its full allowance of Treasury bills to absorb domestic liquidity in the first nine months of the year, and has since relied on central bank certificates of deposit (CDs) and additional foreign exchange auctions. Broad money and reserve money growth through October were 15.5 percent and 10.9 percent, compared to 17 and 11 percent, respectively, at end-2007. The benchmark deposit rate was lowered from 13 percent to 12 percent in January 2009.

The external current account shifted to a deficit of 7 percent of GDP in 2007, compared with an average surplus of about 2.4 percent during 2002-06. This shift reflected mainly FDI-financed imports for a liquefied natural gas (LNG) plant. The external accounts benefited from record oil prices during the first part of the 2008 , but pressures appear to be emerging in the wake of declining oil prices. The current account is projected to remain in deficit (about 2 percent of GDP) in 2008. Gross reserves of the CBY were about $\$ 6.8$ billion at end-2007, and are likely to be close to that level by end-2008.

Some progress has been made on structural reforms. The long-delayed General Sales Tax (GST) was implemented in 2007, but was only applied to a relatively narrow segment of taxpayers-full implementation is slated for 2009. A tax simplification process is currently in train which should eliminate exemptions in the customs, income tax, and investment laws as a precursor to lowering the income tax rate from 35 percent to 20 percent. Other important measures include the passage of a deposit insurance law, and the submission of a microfinance law to parliament. Efforts were also made to improve the investment climate through launching a one-stop shop (making it possible to complete business start-up at a single location) enacting a new procurement law, establishing an anticorruption authority, and reviewing labor and company laws.

\section{Executive Board Assessment}

Executive Directors noted that Yemen's non-oil GDP growth has been solid in recent years. Progress has been made on a number of structural reforms, and Yemen's financial system has remained resilient to the global financial crisis. 
At the same time, Directors noted that downside risks to macroeconomic stability and fiscal and external sustainability have risen considerably in recent months as a result of the slowdown in global economic growth and the decline in oil prices. In addition, the authorities face the medium-term challenge of diversifying the economy and the government revenue base in light of the expected exhaustion of oil reserves and revenue. Their task will be complicated by rapid population growth, inadequate infrastructure, and weak institutional capacity.

Directors were encouraged by the authorities' recognition of the challenges ahead, and welcomed the recent actions to adapt to the rapid fall in oil revenue. However, a determined policy response, involving further macroeconomic adjustment and accelerated structural reforms, is needed in the period ahead. These efforts need to be supported by adequate assistance on concessional terms from the international community.

Directors noted the high risk of debt distress illustrated in the Debt Sustainability Analysis. They considered an ambitious fiscal consolidation effort to be the linchpin of successful adjustment to declining oil prices and production. They agreed that the fiscal stance for 2009 may need to be tightened further, and called for the early implementation of key revenue and expenditure reforms and development of a prudent debt management strategy.

Directors welcomed the authorities' commitment to reduce expenditure in the event that oil prices remain below the benchmark price in the 2009 budget. They stressed the need to strengthen public financial management and further prioritize public spending. This should involve the gradual elimination of fuel subsidies in the current environment of low international fuel prices, accompanied by a public education campaign and strengthening of the social safety net. Directors also called for continued civil service reform and wage restraint to reduce the large public sector wage bill.

On revenue, Directors welcomed the commitment by the authorities to fully implement the General Sales Tax. They encouraged further efforts to broaden the tax base and to strengthen tax administration in order to expand the non-oil revenue base.

Directors supported the commitment of the central bank to continue to focus on price stability. They encouraged the authorities to improve the monetary policy framework, including through improved coordination with fiscal policy and the broadening of the range of monetary policy instruments. The recent reduction of the benchmark deposit rate is welcome, and should be followed by further liberalization of interest rates and development of an inter-bank money market.

Directors supported the current policy of maintaining a stable exchange rate to help achieve the authorities' inflation objective. However, they believed that greater exchange rate flexibility allowing for a real effective depreciation of the currency may be needed in the medium term to preserve external sustainability.

Directors welcomed the improvement in financial sector indicators. They observed that the low level of financial intermediation remains a constraint on economic growth, calling for continued financial sector reforms. The strengthening of minimum capital requirements and the 
establishment of a deposit insurance scheme are welcome in this regard. Directors highlighted the need to strengthen bank regulation and supervision, and encouraged the authorities to request an FSAP update.

Directors underscored the importance of further structural reforms aimed at expanding non-oil production and enhancing Yemen's competitiveness. They welcomed the improvement in Yemen's investment environment, and urged the authorities to keep up the pace of reform with a focus on transparency and good governance. Directors supported ongoing progress in introducing a microfinance law, in developing a framework for combating money laundering and terrorism financing, and seeking closer economic integration through discussions with the GCC and the WTO.

Directors welcomed the efforts to improve the quality and timeliness of macroeconomic statistics, and saw a need for continued technical assistance in this area.

Public Information Notices (PINs) form part of the IMF's efforts to promote transparency of the IMF's views and analysis of economic developments and policies. With the consent of the country (or countries) concerned, PINs are issued after Executive Board discussions of Article IV consultations with member countries, of its surveillance of developments at the regional level, of post-program monitoring, and of ex post assessments of member countries with longer-term program engagements. PINs are also issued after Executive Board discussions of general policy matters, unless otherwise decided by the Executive Board in a particular case. 
Republic of Yemen: Selected Macroeconomic Indicators, 2004-08

Quota $=$ SDR 243.5 million

Population $=22$ million $(2007)$

Per capita income $=$ US\$ $970(2007)$

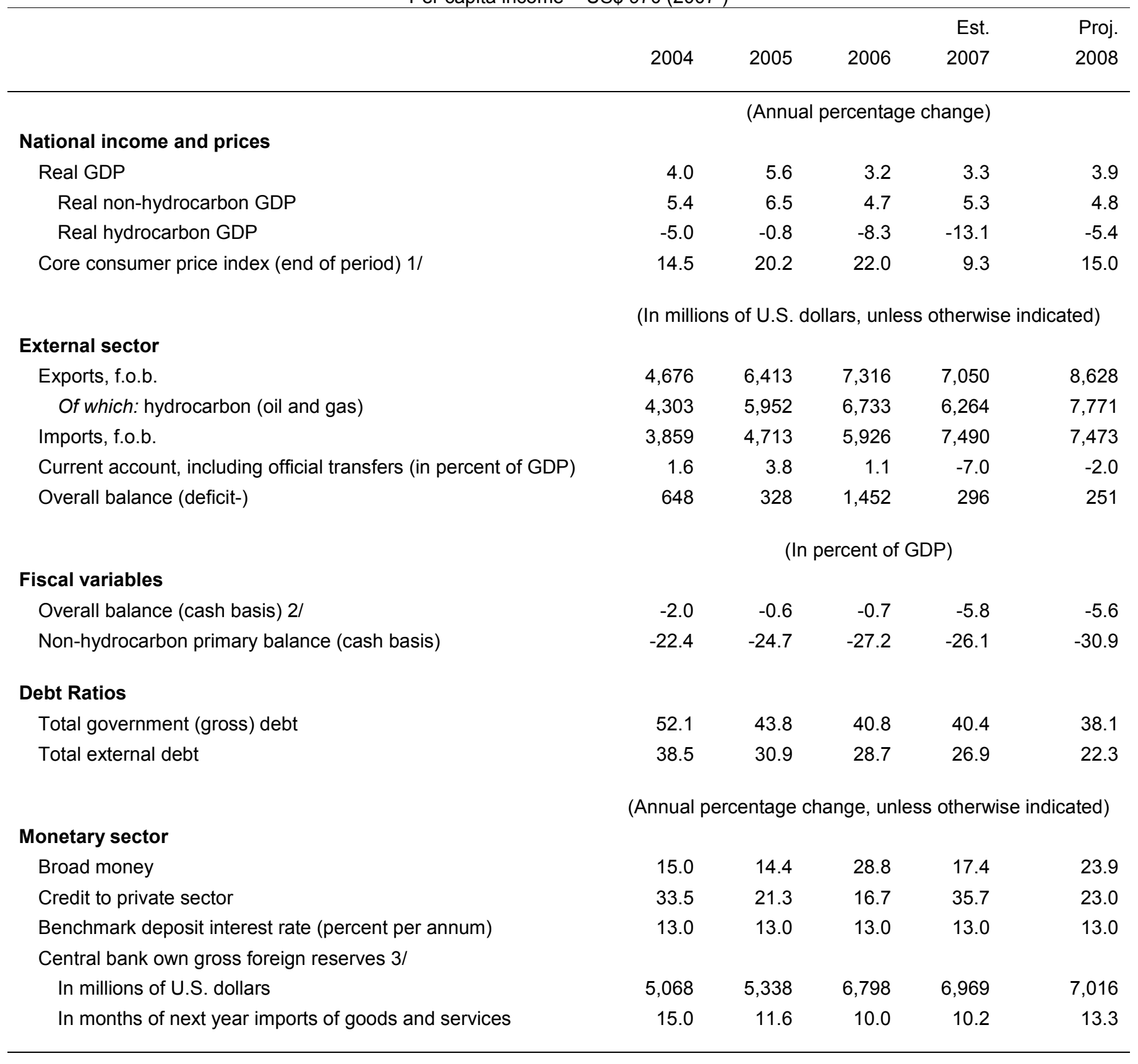

Sources: Yemen authorities; and Fund staff estimates and projections.

$1 /$ Core CPI is defined as the overall CPI less the CPI for qat.

2/ Includes statistical discrepancy.

3/ Gross reserves minus commercial bank and pension fund foreign exchange deposits held with the central bank. 


\section{Statement by Shakour Shaalan, Executive Director for the Republic of Yemen February 23, 2009}

1. Wide-ranging macroeconomic and structural reforms undertaken over the past decade - exchange rate unification and reforms in the fiscal, financial, and structural areashave helped underpin the robust economic performance in recent years. Chief among the authorities' initiatives are reforms of the civil service, public financial management, major adjustment to fuel subsidies, introduction of a new general sales tax (GST), an anticorruption drive, and improvements in the social safety net. Admittedly, however, the authorities have had to balance their desire for a more rapid pace of transformation with potential social tensions arising from relatively high levels of unemployment and poverty. The Fund has played a critical role in supporting macroeconomic stability and in promoting the reform momentum, highlighting the vulnerabilities emanating from the prospective depletion of oil reserves. The authorities have generally shared and greatly valued Fund advice, and are intent on deepening the ongoing economic transformation to address the new challenges.

\section{Recent Developments and Prospects}

2. Economic performance has been affected by the ongoing global recessionary conditions as well as declining oil production and lower oil prices in the latter part of 2008 . Non-oil economic activity is estimated at slightly below 5 percent in 2008, offsetting the decline in oil activity and allowing for overall real GDP growth of 4 percent. Declining oil production contributed to pressures on the external current account in 2007, as did FDI-financed imports for a new liquefied natural gas plant, but the current account deficit narrowed to 2 percent of GDP in 2008. Foreign exchange reserves rose to over 13 months of imports at end 2008.

3. Declining oil production has impinged on Yemen's sound fiscal position and on medium-term fiscal sustainability. The overall fiscal deficit, which had been contained at about $1 / 2$ percent of GDP in 2005 and 2006, swelled to over 5 percent of GDP in 2007 and 2008. To mitigate the impact of surging commodity prices on low-income families, the authorities increased wages, pensions, and social welfare transfers and intervened to increase the supply of basic food commodities in the first half of the year. In spite of efforts to contain other expenditures, lower oil revenues could not be offset by commensurate increases in non-oil revenues and expenditure reductions while preserving social cohesion. In the face of rising budgetary financing and imported inflationary pressures, the Central Bank of Yemen (CBY) maintained exchange rate stability and tightly controlled liquidity through selling Treasury bills and CBY certificates of deposit, as well as foreign exchange auctions. These measures were effective in slowing down growth in monetary aggregates and inflation, which surged to 25 percent in mid-2008, came down to 11 percent by year-end.

4. Yemen has been sheltered from the direct impact of the financial crisis but remains vulnerable to commodity shocks and to global economic activity. The banking system has low exposure to investments and financing through international credit markets and there is no domestic stock market. Inflationary pressures stemming from high imported inflation have seen a gradual reversal in recent months. A decline in regional growth could affect remittances and non-oil foreign investment, thereby increasing the dependence on official 
financing flows. The key challenge is to adjust to the sharp decline in oil production, lower budgetary oil revenue, and foreign exchange receipts. Liquefied natural gas production will help soften this adjustment somewhat for the next ten years, but the authorities are well aware of the need to bolster non-hydrocarbon activity.

\section{Fiscal Policy and Debt Sustainability}

5. The Yemeni authorities recognize the risks to public finances and external sustainability that have emerged since the end of the oil price boom. As oil prices began to decline in the latter part of 2008, measures were taken to compress expenditures including fuel subsidies by raising the price of diesel to industrial users, so as to contain the deficit to around $5 \frac{1}{2}$ percent of GDP, slightly below the 2007 level. The 2009 budget was originally formulated on the basis of a crude oil price of $\$ 55$, but they have since prepared scenarios based on a crude price of $\$ 40$ and $\$ 30$. A cabinet decision was adopted in December 2008 that outlines cuts to a broad range of expenditure line items, reaching 50 percent of the budgeted amounts in some instances. These cuts, amounting to 1.3 percent of GDP, will be painful to bear and unpopular, particularly ahead of the April general elections. About onehalf of the expected saving will be generated from a 13 percent reduction in outlays for costs of goods and services, while preserving priority programs such as security and hospital care. The remainder of the expenditure cuts will be attained through reductions in subsidies, bonuses and allowances and unclassified expenditures. The measures aim to limit the deficit to $8 \frac{1}{2}$ percent of GDP at an average crude oil price of $\$ 40$ per barrel in 2009 .

6. The authorities share the view that a sizable consolidation effort, in the range of 2 percent of GDP annually, will be needed to ensure fiscal and debt sustainability over the medium and longer term as oil revenues taper off. They are in broad agreement with the measures proposed that emphasize boosting non-oil revenue and trimming government expenditures. On the revenue side, they are considering reducing during 2009 the exemptions on the GST that were introduced in January 2007, and to raise the rate from 5 to 10 percent. They have submitted to parliament a tax simplification project that is intended to reduce the highest tax rate from 35 to 20 percent while eliminating exemptions to income and customs taxes - a project that would broaden the tax base while reducing the administrative burden on the private sector. They are also considering ways to contain the wage bill in nominal terms and to increase domestic fuel prices to align them with international prices - but these measures cannot realistically be introduced prior to mid-year.

7. The authorities concur with the conclusions of the debt sustainability analysis (DSA) which underscores the potential vulnerabilities of debt dynamics in Yemen. They recognize that the ratio of debt to GDP could rise rapidly if no measures are taken to contain a widening fiscal deficit. They note, however, that public debt remains relatively low and that a debt law is currently under discussion that will set ceilings for domestic, external, and overall public debt. Given the high risk of debt distress, the authorities are hopeful that all donors, and not only GCC countries, would be mindful of the need for a high degree of concessionality. 


\section{Monetary and Financial Sector Policies}

8. Stability of the rial vis-a-vis the U.S. dollar has helped enhance confidence in the currency, reduce dollarization, and dampen imported inflationary pressure. The authorities consider the level of the exchange rate to be appropriate and welcomed the same conclusion in the staff's assessment. CBY officials intend to remain vigilant in monitoring and controlling excess liquidity through selling Treasury bills and CBY certificates of deposit, as well as foreign exchange auctions. In view of the decline in headline inflation to the target of 15 percent by end-December, the authorities reduced the benchmark interest rate on deposits from 13 percent to 12 percent in early February. If needed, they will consider raising reserve requirements and use Shari'a compliant monetary policy instruments.

9. The authorities consider developing a vibrant financial system to be a high priority. Over the past year, they initiated a number of reforms, including passage of a deposit insurance law, establishment of a deposit insurance corporation, raising banks' minimum capital requirements, submission to parliament of a microfinance law, and relaxing limits on opening Islamic bank branches. They are committed to stringent enforcement of prudential standards and to address weaknesses in contract enforcement, which would encourage banks to expand their clientele.

\section{Structural Reforms and Investment Climate}

10. The Yemeni government will continue its efforts to further diversify the economy and promote alternative sources of growth and employment generation. In addition to the gas sector, there has been a concurrent focus on strategies to promote the development of the country's tourism and maritime activities, to capitalize on the coastal location and cultural heritage. To encourage investments into these areas, they have undertaken a number of initiatives to strengthen the investment climate. Key among these are the establishment of a one-stop shop for investors, a new procurement law, and an active anticorruption authority; as well as a comprehensive review of the company and labor laws. Consequent to these efforts, Yemen's ranking on the World Bank's Doing Business report jumped from 113 in 2008 to 98 in 2009.

11. Intensified donor support will be critical in view of the significant immediate challenges and vast development needs. Donor support has been instrumental in helping to sustain the authorities' reform efforts aimed at tackling problems of widespread poverty and limited institutional and implementation capacity. As highlighted in the donor briefing in Sana'a on February 7, 2009, the authorities are well cognizant of the need for drastic adjustment to bridge the gap between domestic resources and human and physical capital development needs. Donor support can soften the pace of adjustment and help bring about broader acceptance of the transformation.

12. Finally, I would like to convey the Yemeni authorities' appreciation to the staff and management for the collaborative engagement with the Fund. They particularly appreciate staff's valuable policy advice during the Article IV mission and helpful technical assistance they continue to receive from the Fund. They look forward to continued dialogue on the policy priorities in the period ahead. 